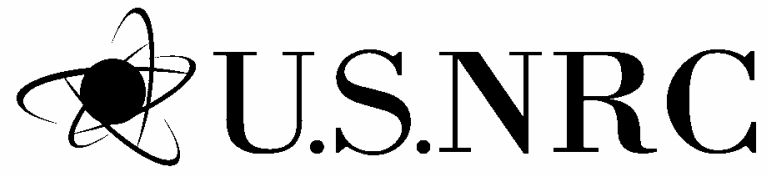

NUREG/CR-6979 ORNL/TM-2007/083

United States Nuclear Regulatory Commission

Protecting People and the Environment

\title{
Evaluation of the French Haut Taux de Combustion (HTC) Critical Experiment Data
}


United States Nuclear Regulatory Commission

Protecting People and the Environment

\section{Evaluation of the French Haut Taux de Combustion (HTC) Critical Experiment Data}

Manuscript Completed: June 2007

Date Published: September 2008

Prepared by

D.E. Mueller, K.R. Elam, and P.B. Fox

Oak Ridge National Laboratory

Managed by UT-Battelle, LLC

Oak Ridge, TN 37831-6170

M. Aissa, NRC Project Manager

NRC Job Code Y6517 


\section{AVAILABILITY OF REFERENCE MATERIALS \\ IN NRC PUBLICATIONS}

\section{NRC Reference Material}

As of November 1999, you may electronically access NUREG-series publications and other NRC records at NRC's Public Electronic Reading Room at http://www.nrc.gov/reading-rm.html. Publicly released records include, to name a few, NUREG-series publications; Federal Register notices; applicant, licensee, and vendor documents and correspondence; NRC correspondence and internal memoranda; bulletins and information notices; inspection and investigative reports; licensee event reports; and Commission papers and their attachments.

NRC publications in the NUREG series, NRC regulations, and Title 10, Energy, in the Code of Federal Regulations may also be purchased from one of these two sources:

1. The Superintendent of Documents

U.S. Government Printing Office

P.O. Box SSOP

Washington, DC 20402-0001

Internet: bookstore.gpo.gov

Telephone: 202-512-1800

Fax: 202-512-2250

2. The National Technical Information Service Springfield, VA 22161-0002

www.ntis.gov

1-800-553-6847 or, locally, 703-605-6000

A single copy of each NRC draft report for comment is available free, to the extent of supply, upon written request as follows:

Address: Office of the Chief Information Officer, Reproduction and Distribution

Services Section

U.S. Nuclear Regulatory Commission

Washington, DC 20555-0001

E-mail: DISTRIBUTION@nrc.gov

Facsimile: 301-415-2289

Some publications in the NUREG series that are posted at NRC's Web site address http://www.nrc.gov/reading-rm/doc-collections/nuregs are updated periodically and may differ from the last printed version. Although references to material found on a Web site bear the date the material was accessed, the material available on the date cited may subsequently be removed from the site.

\section{Non-NRC Reference Material}

Documents available from public and special technical libraries include all open literature items, such as books, journal articles, and transactions, Federal Register notices, Federal and State legislation, and congressional reports. Such documents as theses, dissertations, foreign reports and translations, and non-NRC conference proceedings may be purchased from their sponsoring organization.

Copies of industry codes and standards used in a substantive manner in the NRC regulatory process are maintained at-

$$
\begin{aligned}
& \text { The NRC Technical Library } \\
& \text { Two White Flint North } \\
& 11545 \text { Rockville Pike } \\
& \text { Rockville, MD 20852-2738 }
\end{aligned}
$$

These standards are available in the library for reference use by the public. Codes and standards are usually copyrighted and may be purchased from the originating organization or, if they are American National Standards, from-
American National Standards Institute 11 West $42^{\text {nd }}$ Street
New York, NY 10036-8002
www.ansi.org
212-642-4900

Legally binding regulatory requirements are stated only in laws; NRC regulations; licenses, including technical specifications; or orders, not in NUREGseries publications. The views expressed in contractor-prepared publications in this series are not necessarily those of the NRC.

The NUREG series comprises (1) technical and administrative reports and books prepared by the staff (NUREG/XXXX) or agency contractors (NUREG/CR-XXXX), (2) proceedings of conferences (NUREG/CP-XXXX), (3) reports resulting from international agreements (NUREG/IA-XXXX), (4) brochures (NUREG/BR$X X X X)$, and (5) compilations of legal decisions and orders of the Commission and Atomic and Safety Licensing Boards and of Directors' decisions under Section 2.206 of NRC's regulations (NUREG0750).

DISCLAIMER: This report was prepared as an account of work sponsored by an agency of the U.S. Government. Neither the U.S. Government nor any agency thereof, nor any employee, makes any warranty, expressed or implied, or assumes any legal liability or responsibility for any third party's use, or the results of such use, of any information, apparatus, product, or process disclosed in this publication, or represents that its use by such third party would not infringe privately owned rights. 



\begin{abstract}
In the 1980s, a series of critical experiments referred to as the Haut Taux de Combustion (HTC) experiments was conducted by the Institut de Radioprotection et de Sûreté Nucléaire (IRSN) at the experimental criticality facility in Valduc, France. The plutonium-to- uranium ratio and the isotopic compositions of both the uranium and plutonium used in the simulated fuel rods were designed to be similar to what would be found in a typical pressurized-water reactor fuel assembly that initially had an enrichment of $4.5 \mathrm{wt} \%{ }^{235} \mathrm{U}$ and was burned to $37,500 \mathrm{MWd} / \mathrm{MTU}$. The fuel material also includes ${ }^{241} \mathrm{Am}$, which is present due to the decay of ${ }^{241} \mathrm{Pu}$. The HTC experiments include configurations designed to simulate fuel handling activities, pool storage, and transport in casks constructed of thick lead or steel.

Rights of use for the HTC experiment data were purchased under an agreement that limits release of the information. Consequently, a detailed and complete description of the experiments is not presented in this report. This report discusses evaluation of the four HTC data reports, modeling of the experiments, sensitivity and uncertainty analysis, and upper subcritical limit (USL) calculation. The report also presents some conclusions and recommendations concerning use of the HTC experiment data for burnup credit applications.

The similarity of the HTC experiments with PWR spent nuclear fuel has been quantified using sensitivity/uncertainty analysis, confirming that the HTC experiments are significantly more applicable to the validation of burnup credit calculations than other available mixed-oxide (MOX) experiments. The HTC experiments were designed and executed with a high level of rigor, resulting in experimental uncertainties that are lower than many of the earlier MOX experiments. The HTC data reports, together with information provided in this report, provide sufficient data to allow for either detailed or simplified computational models to be developed. The HTC experiments substantially strengthen the technical basis for validation by adding to the previously small number of applicable experiments against which to compare burnup credit applications. Existing MOX experiments found to be applicable are also identified in this report.
\end{abstract}




\section{FOREWORD}

In 1999 the United States Nuclear Regulatory Commission (U.S. NRC) issued initial recommended guidance for using reactivity credit due to fuel irradiation (i.e., burnup credit) in the criticality safety analysis of spent pressurized-water-reactor (PWR) fuel in storage and transportation packages. This guidance was issued by the NRC Spent Fuel Project Office (SFPO) as Revision 1 to Interim Staff Guidance 8 (ISG8RI) and published in the Standard Review Plan for Transportation Packages for Spent Nuclear Fuel, NUREG-1617 (March 2000). With this initial guidance as a basis, the NRC Office of Nuclear Regulatory Research initiated a program to provide the SFPO with technical information that would:

- enable realistic estimates of the subcritical margin for systems with spent nuclear fuel (SNF) and an increased understanding of the phenomena and parameters that impact the margin, and

- support the development of technical bases and recommendations for effective implementation of bumup credit and provide realistic SNF acceptance criteria while maintaining an adequate margin of safety.

An outcome of the research program was Revision 2 to Interim Staff Guidance 8 (ISG8R2), which expanded the guidance to: (1) extend the range of allowed burnup and cooling time; (2) allow loading of assemblies exposed to burnable absorbers; (3) remove the loading offset for initial ${ }^{235} \mathrm{U}$ enrichments between 4 and 5 percent; and (4) indicate an acceptable source for selecting a bounding axial burnup profile(s). The Recommendation that burnup credit be based on only the actinide compositions remained unchanged, and hence a focus of current work is to investigate the technical basis for enabling credit for fission products. A significant number of domestic and international studies have been performed to help understand the components that influence the negative reactivity available with burnup credit, including the presence of the fission product nuclides. However, the availability of adequate experimental benchmark data for validation has continued to be an issue. The purpose of this study was to evaluate a series of critical experiments that has recently become available for the purpose of solidifying criticality validation for actinide-only burnup credit. Strengthening the criticality validation for the actinide compositions is considered a prudent prerequisite to enabling credit for fission products. The series of critical experiments evaluated in this report, referred to as the Haut Taux de Combustion (HTC) experiments, was conducted by the Institut de Radioprotection et de Sûreté Nucléaire (IRSN) at the experimental criticality facility in Valduc, France. These experiments involve rods manufactured to simulate spent fuel in terms of their uranium and plutonium compositions and include configurations designed to simulate fuel handling activities, pool storage, and transport in casks constructed of thick lead or steel. The report discusses an evaluation of the HTC critical experiment data, modeling of the experiments, sensitivity and uncertainty analysis, and upper subcritical limit (USL) determinations based on the HTC data. The HTC experiments are shown to substantially strengthen the technical basis for validation by adding to the previously small number of applicable experiments against which to compare burnup credit applications.

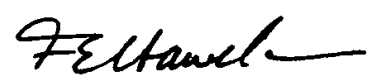

Farouk Eltawila, Director

Division of Systems Analysis 


\section{TABLE OF CONTENTS}

$\underline{\text { Page }}$

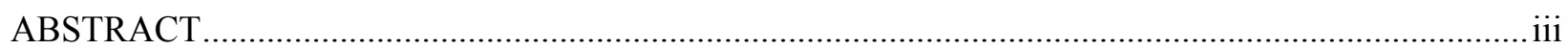

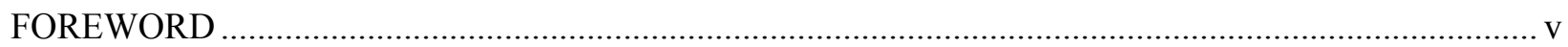

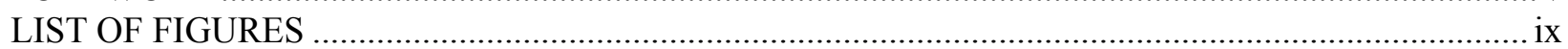

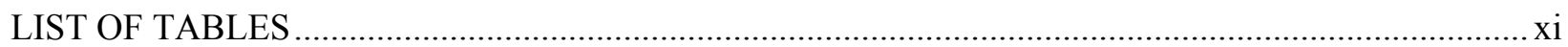

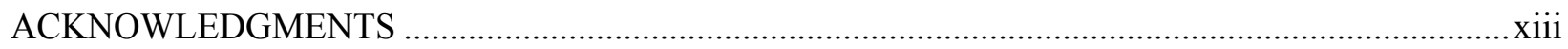

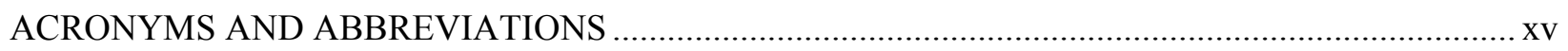

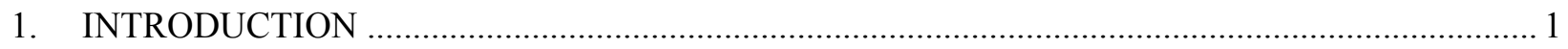

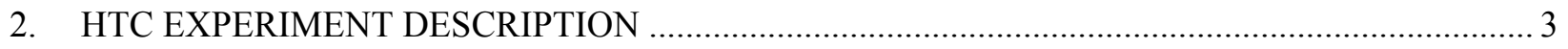

3. EVALUATION OF HTC REPORTS/DATA …...................................................................... 7

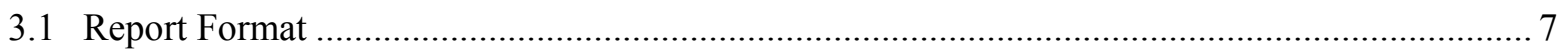

3.2 Uncertainty Analyses .................................................................................... 7

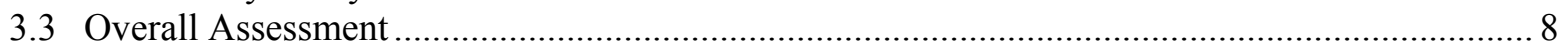

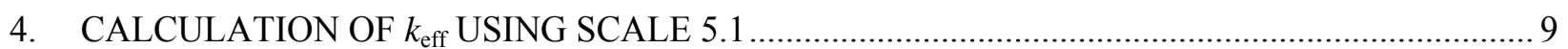

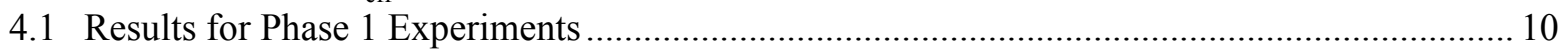

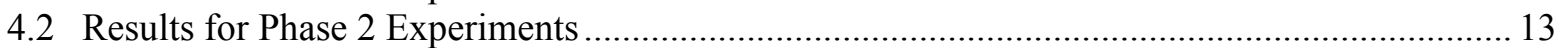

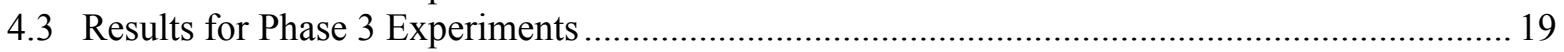

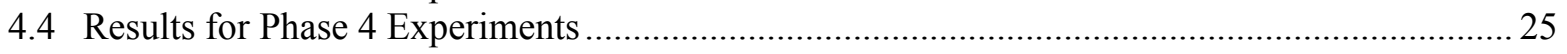

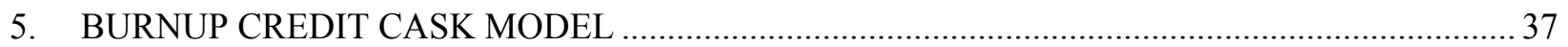

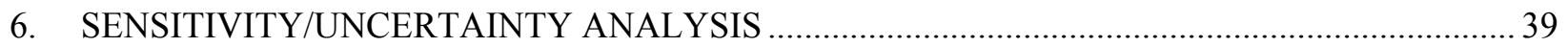

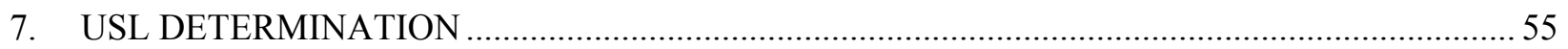

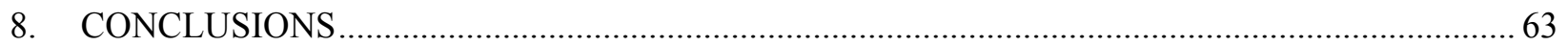

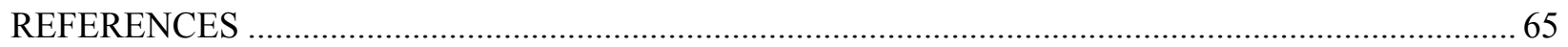




\section{LIST OF FIGURES}

$\underline{\text { Page }}$

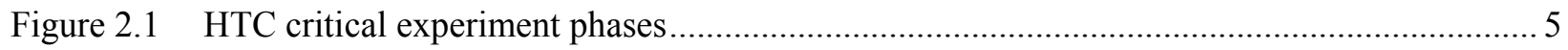

Figure 4.1 KENO-3D representation of a Phase 1 critical configuration with a quadrant removed....... 11

Figure 4.2 Phase 1 calculated $k_{\text {eff }}$ as a function of fuel rod pitch ..................................................... 13

Figure 4.3 Calculated $k_{\text {eff }}$ values vs pin pitch for Phase 2 gadolinium experiments ........................... 15

Figure 4.4 Calculated $k_{\text {eff }}$ values vs gadolinium concentration for Phase 2 gadolinium

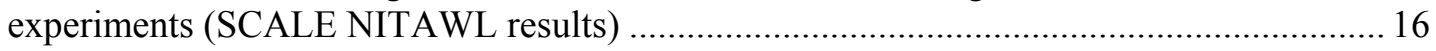

Figure 4.5 Calculated $k_{\text {eff }}$ values vs pin pitch for Phase 2 boron experiments .................................... 18

Figure 4.6 Calculated $k_{\text {eff }}$ values vs boron concentration for Phase 2 boron experiments (results using SCALE CSAS25 with NITAWL cross section processing)............................ 19

Figure 4.7 KENO-3D representation of a Phase 3 critical configuration with a section removed ......... 21

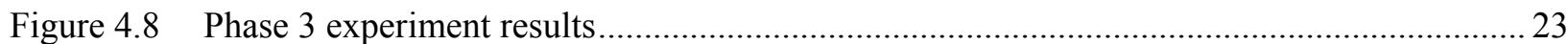

Figure 4.9 Calculated $k_{\text {eff }}$ values for Phase 3 experiments having absorber panels as a function of spacing between assemblies

Figure 4.10 Calculated $k_{\text {eff }}$ values for Phase 3 experiment without absorber panels as a function

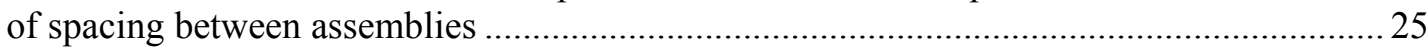

Figure 4.11 KENO-3D representation of a typical Phase 4 experiment ............................................... 26

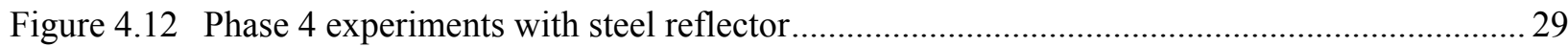

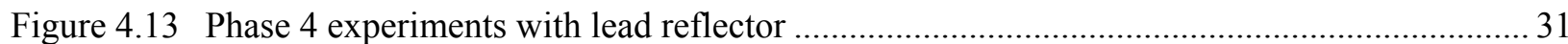

Figure 4.14 Variation of calculated $k_{\text {eff }}$ with changes in the size of the gap between assemblies in the steel reflected cases

Figure 4.15 Variation of calculated $k_{\text {eff }}$ with changes in the size of the gap between assemblies in the lead reflected cases

Figure 4.16 Variation of calculated $k_{\text {eff }}$ with changes in the gap size between the assemblies and the steel reflector

Figure 4.17 Variation of calculated $k_{\text {eff }}$ with changes in the gap size between the assemblies and the lead reflector

Figure 5.1 Cutaway view of the KENO V.a model for the GBC-32 cask showing the cask

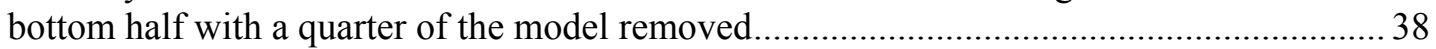

Figure 6.1 Relative actinide isotope importance in the GBC-32 cask .............................................. 40

Figure 6.2 Comparison of HTC experiments to GBC-32 cask model with $40 \mathrm{GWd}$ /MTU fuel............ 41

Figure 6.3 Variation of $c_{k}$ with HTC experiment fuel pin pitch.

Figure 6.4 Comparison of HTC experiments to GBC-32 cask model with fuel burned to 10, 20, 40 , and $70 \mathrm{GWd} / \mathrm{MTU}$

Figure 6.5 Comparison of non-HTC MOX and HTC experiments to the GBC-32 cask model with $40 \mathrm{GWd} / \mathrm{MTU}$ fuel 


\section{LIST OF FIGURES}

$\underline{\text { Page }}$

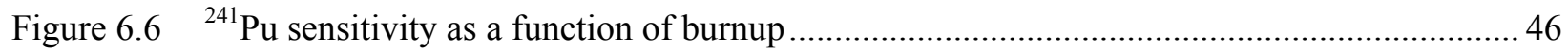

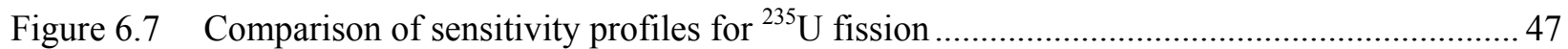

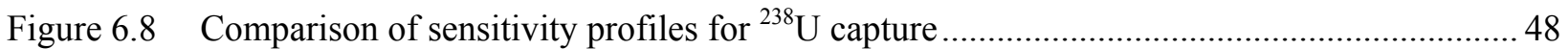

Figure 6.9 Comparison of sensitivity profiles for ${ }^{239} \mathrm{Pu}$ fission............................................................ 49

Figure 6.10 Comparison of sensitivity profiles for ${ }^{241} \mathrm{Pu}$ fission........................................................... 50

Figure 6.11 Comparison of total sensitivity profiles for ${ }^{241} \mathrm{Am}$.................................................... 51

Figure 6.12 Comparison of sensitivity profiles for ${ }^{1} \mathrm{H}$ scatter.............................................................52

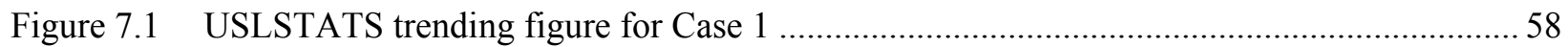

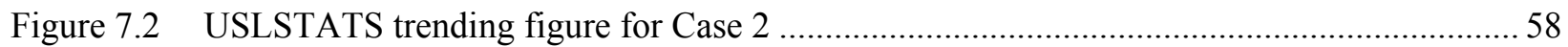

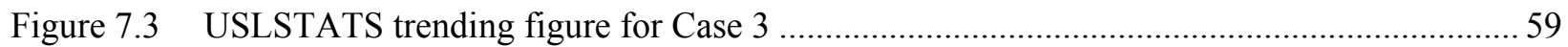

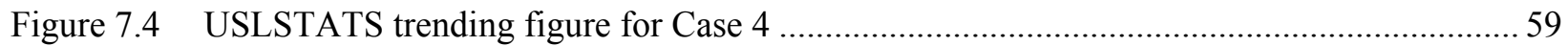

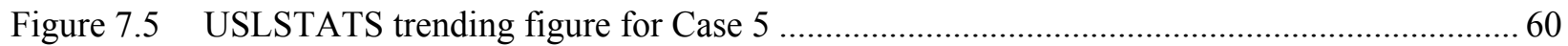

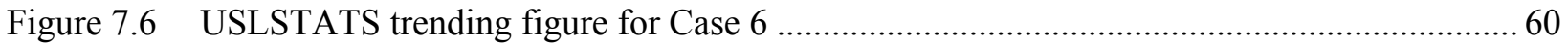

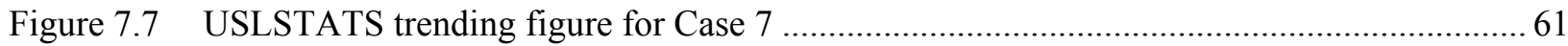

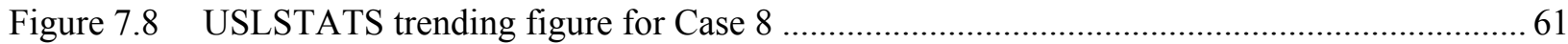




\section{LIST OF TABLES}

$\underline{\text { Page }}$

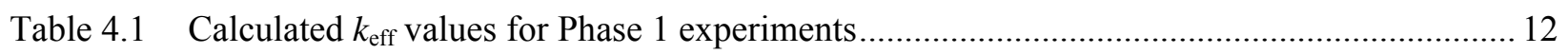

Table 4.2 Calculated $k_{\text {eff }}$ values for Phase 2 experiments with gadolinium ........................................ 14

Table 4.3 Calculated $k_{\text {eff }}$ values for Phase 2 experiments with boron ................................................ 17

Table 4.4 Calculated $k_{\text {eff }}$ values for Phase 3 experiments...............................................................2 22

Table 4.5 Calculated $k_{\text {eff }}$ values for Phase 4 experiments with steel reflector...................................... 28

Table 4.6 Calculated $k_{\text {eff }}$ values for Phase 4 experiments with lead reflector ....................................... 30

Table 5.1 Uranium and plutonium compositions for burned PWR fuel ............................................... 38

Table 6.1 Calculated $c_{k}$ values for non-HTC MOX experiments compared with GBC-32 model loaded with W $17 \times 17$ fuel burned to $40 \mathrm{GWd} / \mathrm{MTU}$........................................................... 45

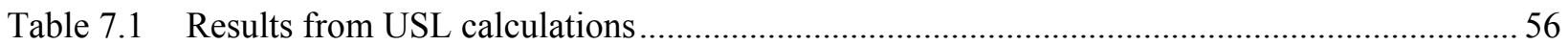




\section{ACKNOWLEDGMENTS}

This work was performed under contract with the Office of Nuclear Regulatory Research, U.S. Nuclear Regulatory Commission (NRC). The authors gratefully acknowledge C. V. Parks and J. C. Wagner of Oak Ridge National Laboratory (ORNL) for providing guidance for this work and valuable comments/suggestions on the draft report. We would like to thank NRC staff for useful discussions, suggestions, and review of this document. In addition, we are grateful for the technical reviews and comments provided by S. Goluoglu and B. W. Patton, editorial assistance by C. C. Southmayd, and the support provided by D. J. Weaver in the preparation of this report. 


\section{ACRONYMS AND ABBREVIATIONS}

B-SS

EALF

HTC

IHECSBE

IRSN

MOX

NRC

ORNL

PWR

SDF

USL

W17×17OFA borated stainless steel

energy of average lethargy of neutrons causing fission

Haut Taux de Combustion

International Handbook of Evaluated Criticality Safety Benchmark

Experiments

Institut de Radioprotection et de Sûreté Nucléaire

mixed oxide

Nuclear Regulatory Commission

Oak Ridge National Laboratory

pressurized water reactor

sensitivity data file

upper subcritical limit

Westinghouse $17 \times 17$ Optimized Fuel Assemblies 


\section{INTRODUCTION}

In the 1980s, a series of critical experiments referred to as the Haut Taux de Combustion (HTC) experiments was conducted by the Institut de Radioprotection et de Sûreté Nucléaire (IRSN) at the experimental criticality facility in Valduc, France. These experiments were designed to provide a basis for validation of actinide-only burnup credit calculations. The simulated fuel rods used in these experiments contained a mixture of uranium and plutonium oxides. The plutonium-to-uranium ratio and the isotopic compositions of both the uranium and plutonium were designed to be similar to what would be found in a typical pressurized-water reactor (PWR) fuel assembly that initially had an enrichment of $4.5 \mathrm{wt} \%{ }^{235} \mathrm{U}$ and was burned to $37,500 \mathrm{MWd} / \mathrm{MTU}$. The fuel material also includes ${ }^{241} \mathrm{Am}$, which is present due to the decay of ${ }^{241} \mathrm{Pu}$.

The 156 critical configurations were designed to approximate fuel handling, fuel storage rack, and spent fuel shipping cask conditions and were categorized into four phases. The first phase (Phase 1) included 18 configurations, each involving a single square-pitched array of rods with rod pitch varying from 1.3 to $2.3 \mathrm{~cm}$. The arrays were flooded and reflected with clean water. The second phase (Phase 2) included 41 configurations that were similar to the first group except that the water used as moderator and reflector included either boron or gadolinium in solution. The third phase (Phase 3) included 26 configurations with the rods arranged into four assemblies in a $2 \times 2$ array to simulate fuel assembly storage rack conditions. The spacing between assemblies was varied, and some of the assemblies had borated stainless steel (B-SS), Boral ${ }^{\circledR}$, or cadmium plates attached to the sides of the four assemblies. The fourth phase (Phase 4) simulated cask conditions and included 71 configurations similar to the Phase 3 configurations except thick steel or lead shields were placed around the outside of the $2 \times 2$ array of fuel assemblies. A total of 156 configurations are documented in the final reports. ${ }^{1-4}$

The HTC experiments have many characteristics that make them particularly suited to the validation of actinide-only burnup credit applications. ${ }^{5}$ They improve the ability to perform statistically strong validation studies by adding a significant number of highly applicable critical configurations to the previously small number of less applicable experiments against which to validate burnup credit calculations. Non-HTC critical experiments used in such validations are typically mixed-oxide (MOX) fuel, which does not contain the same proportions of uranium and plutonium that are found in burned fuel. These experiments also typically include natural or depleted uranium, unlike burned fuel that still contains slightly enriched uranium.

The HTC experiments may also be used to validate some of the actinides in calculations that include both actinides and fission products. In this case, the user would still need to address the issue of bias and bias uncertainty resulting from the inclusion of fission products and actinides that are present in the safety analysis, but not in the critical experiments.

Rights of use for the HTC experiment data were purchased under an agreement that limits release of the information. Consequently, a detailed and complete description of the experiments is not presented in this report. This report discusses evaluation of the HTC data ${ }^{1-4}$ for applicability to burnup credit, including modeling of the experiments, sensitivity/uncertainty analysis, and upper subcritical limit (USL) calculation. The report also presents some conclusions and recommendations concerning use of the HTC experiment data for burnup credit applications. 



\section{HTC EXPERIMENT DESCRIPTION}

Rights of use for the HTC experiment data were purchased under an agreement that limits release of the information. Consequently, a detailed and complete description of the experiments is not presented in this report. The data are available in the four experimental reports, listed as Refs. 14. There are currently some restrictions on who may use the data and for what purposes. It is anticipated that data recipients will be required to sign nondisclosure agreements, which include provisions for release of the data to the Nuclear Regulatory Commission and the U.S. Department of Energy.

The HTC experiments were conducted in Apparatus B at the experimental critical facility in Valduc, France, between 1988 and 1990. The fuel rods were fabricated specifically for this set of experiments. The fuel consisted of 1-cm-long pellets contained within Zircaloy-4 cladding. The active fuel length was $90 \mathrm{~cm}$. The fuel rods were held in place by an upper and a lower grid and were contained in one or four assemblies placed into a rectangular tank.

The critical approach was accomplished by varying the water or solution level in the tank containing the fuel pin arrays. The critical condition was extrapolated from a subcritical configuration with a multiplication factor within $0.1 \%$ of 1.000 . The level of rigor associated with these experiments resulted in very low experimental uncertainties (less than $0.2 \%$ in $k_{\text {eff }}$ ).

These experiments were designed to provide a basis for validation of actinide-only burnup credit calculations. The simulated zircalloy-4 clad fuel rods used in these experiments contained a mixture of uranium and plutonium oxides. The plutonium-to-uranium ratio and the isotopic compositions of both the uranium and plutonium were designed to be similar to what would be found in a typical PWR fuel assembly that initially had an enrichment of $4.5 \mathrm{wt} \%{ }^{235} \mathrm{U}$ and was burned to $37,500 \mathrm{MWd} / \mathrm{MTU}$. The fuel material also includes ${ }^{241} \mathrm{Am}$, which is present due to the decay of ${ }^{241} \mathrm{Pu}$. A comparison of the HTC uranium and plutonium compositions with typical burnup credit analysis compositions and with typical SNF are presented in Section 5 of this report.

The critical experiments were designed to approximate fuel handling, fuel storage rack, and spent fuel shipping cask conditions and were categorized into four phases (see Figure 2.1). The first phase included 18 configurations, each involving a single square-pitched array of rods with rod pitch varying from 1.3 to $2.3 \mathrm{~cm}$. The arrays were flooded and reflected with clean water. The second phase included 41 configurations that were similar to the first phase except that the water used as moderator and reflector included either boron or gadolinium in solution at various concentrations. The third phase simulated fuel assembly storage rack conditions and included 26 configurations with the rods arranged into four assemblies in a $2 \times 2$ array. The spacing between assemblies was varied, and some of the assemblies had B-SS, Boral ${ }^{\circledR}$, or cadmium plates attached to the sides of the four assemblies. The fourth phase simulated cask conditions and included 71 configurations similar to the Phase 3 configurations except thick steel or lead shields were placed around the outside of the $2 \times 2$ array of fuel assemblies. A total of 156 configurations are documented in the final reports. ${ }^{1-4}$

Phases 1 and 2 include configurations with pin pitch varying between 1.3 and $2.3 \mathrm{~cm}$. These experiments with varied pin-pitch may be used to examine the effect of varying the level of moderation on the bias resulting from use of a computational method, which is defined as the combination of the computer codes used, nuclear data used, and the way in which they are used, including modeling practices (e.g., region homogenization), neutron transport options selected, 
and cross-section processing options used (e.g., resonance processing). The pin pitch was varied by using different aluminum grid plates, which held the zircalloy-4 clad rods in place.

The Phase 2 configurations include soluble boron at concentrations ranging from 0.089 to $0.595 \mathrm{~g}$ $\mathrm{B} /$ liter or $\mathrm{Gd}$ at concentrations ranging from 0.048 to $0.200 \mathrm{~g} \mathrm{Gd} /$ liter. These configurations support examination of the effect of varying poison concentrations on the bias resulting from the computational method.

The HTC experiments have many characteristics that make them particularly suited to the validation of actinide-only burnup credit applications. ${ }^{5}$ They improve the ability to perform statistically strong validation studies by adding to the previously small number of applicable experiments against which to compare burnup credit applications. Other critical experiments used in such validations are typically mixed-oxide (MOX) fuel, which does not contain the same proportions of uranium and plutonium isotopes that are found in burned fuel. The MOX experiments also typically include natural or depleted uranium, unlike burned fuel that still contains slightly enriched uranium.

The HTC experiments may also be used to validate some of the actinides in calculations that include both actinides and fission products. In this case, the user would still need to address the issue of bias and bias uncertainty resulting from the inclusion of fission products and actinides that are present in the safety analysis, but not in the critical experiments. 


\section{HTC Critical}

Experiments

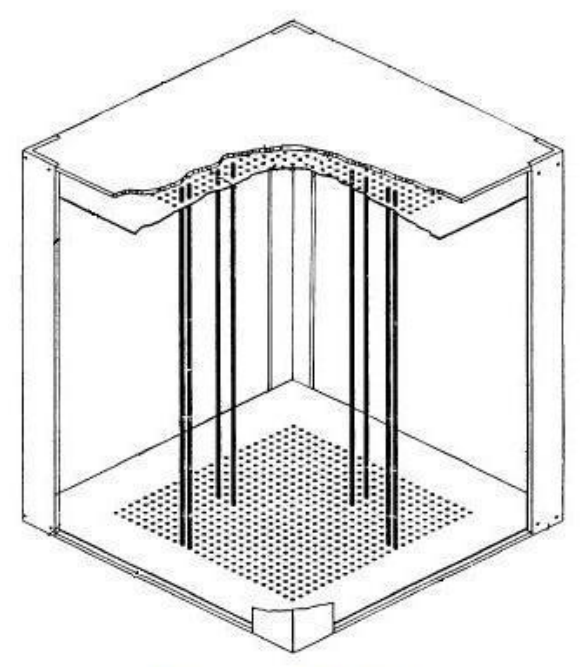

Phases 1 \& 2

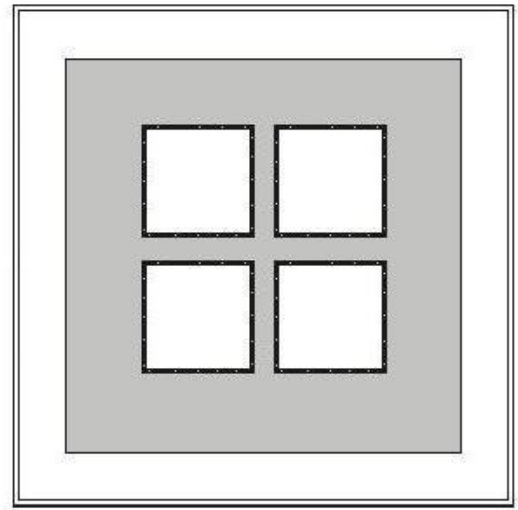

Phase 3
All with MOX rods designed to look like burned fuel

Phase 1-Single array, pin pitch varied, clean water

Phase 2-Single array, pin pitch varied, water with gadolium or boron in solution

Phase 3-Four assemblies, some with borated steel, Boral ${ }^{\mathrm{TM}}$, or cadmium side panels, clean water, assembly spacing varied

Phase 4-Like Phase 3 except thick lead or steel shields around outside of array

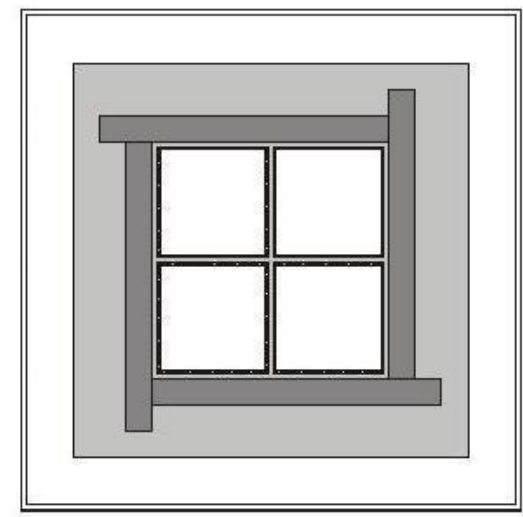

Phase 4

Figure 2.1 HTC critical experiment phases 


\section{EVALUATION OF HTC REPORTS/DATA}

\subsection{Report Format}

The HTC reports were written in a format similar to that used in the International Handbook of Evaluated Critical Safety Benchmark Experiments (IHECSBE). ${ }^{6}$ Section 1 of each report gives a detailed experimental description, including dimensions and material compositions, for each experiment. Section 2 provides data on parameter uncertainties, whether measured or estimated, along with data on the effect these parameter uncertainties have on the calculated value of $k_{\text {eff. }}$. Section 3 presents the proposed benchmark model for each experiment, including component dimensions and atom densities. It also describes any model simplifications suggested by the report authors and an estimate of the effect these simplifications have on calculated $k_{\text {eff }}$ values. Section 4 provides sample calculation results for specified computer codes and cross-section data sets. These results are based on the suggested benchmark model described in Sect. 3 .

The IHECSBE requires that all information needed to produce computer models of the experiments be located in Sect. 3. In most cases, the IRSN reports provide this information in the correct sections. However, some information from Sect. 1 was needed to supplement that found in Sect. 3 to produce the computational models described in Section 4 of this report. For the HTC reports to be published in the IHECSBE, this would need to be corrected.

\subsection{Uncertainty Analyses}

Section 2 in each of the reports provides a detailed analysis of experimental uncertainties and their effects on the calculated value of $k_{\text {eff. }}$ These sections were written in accordance with the current IHECSBE Guide to the Expression of Uncertainties. However, the uncertainties are presented at the $3 \sigma$, or $99.7 \%$, confidence level. IHECSBE uncertainties are given at the $1 \sigma$ level. All parameters normally considered for uncertainty analysis of pin lattice experiments are included. These include fuel pin geometry (fuel diameter, clad diameter, clad thickness), fuel composition (density, isotopic content, impurities), and array parameters (pitch, water height, temperature, water impurities).

In the Phase 1 report, several of the parameters related to fuel composition were found to be minor contributors to the overall uncertainty and were not analyzed further in the Phase 2-4 reports. A 30-pcm (percent millirho $=10^{-5} \Delta \mathrm{k}$ ) uncertainty was added to the uncertainty analyses for Phases 2, 3, and 4 to account for these small contributors. The uncertainty due to possible impurities in the water, and therefore in the poisoned solutions in Phase 2, was evaluated in the Phase 1 report and found to be negligible. Water or solution impurities were not evaluated further in the later reports.

The reports include a small uncertainty associated with the location of the pin in the grid holes; however, the reports do not include an uncertainty associated with the grid hole locations. The report authors have indicated ${ }^{7}$ that the uncertainty associated with the grid hole spacing or pin pitch is insignificant. To date, the grid hole center-to-center spacing has not been measured for the grid plates used in the HTC experiments. It is recommended that HTC data users consider further evaluation of the $\mathrm{k}_{\text {effective }}$ uncertainty related to uncertainty in the average center-to-center spacing of the grid holes. The latest revisions of the HTC reports indicate that the fabrication tolerance on the grid hole locations, taken from fabrication drawings, was $0.01 \mathrm{~cm}$. 
The Phase 1 report concludes that four base parameters contribute most of the experimental uncertainty. These parameters are pellet diameter, clad outer diameter, temperature, and fuel impurities. For Phase 2, the parameters related to gadolinium or boron in the solution are additional major uncertainty contributors.

The critical water height uncertainty contribution is larger for the experiments in Phases 3 and 4 as compared to the uncertainties in Phases 1 and 2. In addition to the usual uncertainty in measuring the critical water height, a factor related to experimental reproducibility is added to this uncertainty. The reproducibility factor includes fuel core loading, location of rods in the grids, position of baskets and support structures in the tank, and the effect of temperature variations in the reflector. The error associated with the reproducibility factor is small for the simpler experiments in Phases 1 and 2 but becomes much larger for experiments with more than one basket in the tank. The $3 \sigma$ water height uncertainty for Phases 1 and 2 is 0.12 and $0.09 \mathrm{~cm}$, respectively. This uncertainty increases to $0.51 \mathrm{~cm}$ for Phases 3 and 4, and the critical water height uncertainty contribution becomes somewhat larger.

For the Phase 3 and 4 reports, additional parameters related to the canisters, which are assemblies with neutron poison panels attached to each side, and shields are included. The Phase 3 report shows that canister thickness (attached poison panel thickness), composition, and position were evaluated for contributions to experimental uncertainty.

There are several configurations in Phases 3 and 4 in which poison panels are attached to the sides of the assemblies and the assemblies placed such that there is no gap between the poison panels on adjacent assemblies. The $k_{\text {eff }}$ values provided by both IRSN and ORNL staff for these configurations (see Figure 4.8, Phase 3 cases 2, 6 and 8; Figure 4.12, Phase 4 SS reflected cases 1, 12 and 14; and Figure 4.13 lead reflected cases 1, 12, 13, 14 and 17) are higher than the $k_{\text {eff }}$ values calculated for the cases that have water-filled gaps between the assemblies. These higher $k_{\text {eff }}$ values could be due to the unmodeled presence of some small amount of water between the poison panels. It is recommended that these cases not be used for validation studies until/unless these differences are better understood.

The Phase 4 report adds screen position to the uncertainty analysis. The Phase 4 report discusses uncertainty in screen thickness and composition but states that these uncertainties were not analyzed. The uncertainty due to screen position is measurable (an average of $73 \mathrm{pcm}$ for the 22 cases analyzed), so it would be reasonable for the uncertainty due to screen thickness and composition to be evaluated in the future.

Overall, the uncertainty analysis appears to be thorough but could be improved to address the observations noted above.

\subsection{Overall Assessment}

The experimental descriptions in the reports are detailed enough to provide adequate data for modeling of the experiments for use in criticality safety validation analyses. 


\section{CALCULATION OF $\boldsymbol{k}_{\text {eff }}$ USING SCALE 5.1}

The primary references for these experiments ${ }^{1-4}$ are written in a format that is similar to criticality benchmark experiment evaluations published in the IHECSBE. ${ }^{6}$ As such, the reports contain a detailed experiment description, an evaluation of experimental uncertainties, a description of a benchmark model (geometry and material specifications) for each experiment, and results of calculations using specific computer code/cross-section data combinations.

Using these reports, ORNL created detailed CSAS25 input files for each of the experiments. SCALE 5.1 (Ref. 8) calculations were performed using both the SCALE ENDF/B-V and ENDF/B-VI 238-group cross sections. The CSAS25 control module utilizes the SCALE 5.1 modules BONAMI and either NITAWL or CENTRM for cross-section processing and then calls KENO-V.a for the Monte Carlo calculation. The lattice cell unit cell option was used to create a problem-specific shielded cross-section set for each calculation. The detailed models, including material number densities, were based on the experiment descriptions in Refs. 1-4.

Detailed models of the structures described in the experimental references were prepared. Resonance processing for the fuel material was done using one mixture number for the fuel above the water line and another mixture number for the fuel pin region that was surrounded by water. This capability to process more than one unit cell per problem was an enhancement that became available with the release of SCALE Version 5. The following modeling approximates were used:

- The spring above the fuel pellet stack was homogenized to a cylinder of reduced density spring steel having inner and outer radii matching those of the spring.

- The top and bottom fuel rod end-plugs are modeled as simple cylinders.

- The pellet stacks above and below the critical water level are each modeled as cylinders.

- The legs holding the pedestal above the bottom of the tank are not modeled.

- The tubular support frame was not modeled.

- The support girders under the stainless steel plates were not modeled.

- Except for the concrete directly under the tank, the room was not modeled. On the sides, the models extend to the outside of the tank wall. On top, the models extend to the top of the basket top plate. On the bottom, the models extend to the bottom of the $40 \mathrm{~cm}$-thick concrete floor.

- Air in and around the experiments was modeled as void.

- The water level measurement system, which is external to the tank, was not modeled.

- Additional minor modeling approximations were made such as not modeling fasteners and glue.

These approximations have little or no impact on the calculated $k_{\text {eff }}$ values.

Detailed descriptions of each of the 156 configurations are provided in the IRSN reports. Out of the 156 configurations only 1 configuration is repeated. Phase 4 lead-reflected experiment numbers 2586 and 2587 are the only repeated configurations. 
Consistent with the practices followed for the IHECSBE, the French reports do state in Section 3 of each of the reports that the expected benchmark model $k_{\text {eff }}$ value for all configurations is 1.0000 . Benchmark model $k_{\text {eff }}$ uncertainty values are also provided for all configurations.

An interesting general observation on the results is that the calculations performed using the SCALE 5.1 ENDF/B-V 238 group library and NITAWL cross-section processing yield $k_{\text {eff }}$ values that are consistently closer to critical than the calculations using the SCALE 5.1 ENDF/B-VI 238 group library and CENTRM cross-section processing. This trend is most likely due to differences between the ENDF/B-V and ENDF/B-VI 238 group libraries. An additional calculation was run using a new ENDF/B-VII 238 group library and CENTRM cross-section processing for a single critical configuration. This result was close to the ENDF/B-V result. This comparison does not mean that any of the data library and cross-section methods are better or worse. Instead, the apparent bias between the results highlights the importance of validating the computational method, which includes computer codes, modeling techniques, input options, and nuclear data, being used in the criticality analysis.

\subsection{Results for Phase 1 Experiments}

This group of experiments consists of lattices of varying size and fuel rod pitch, moderated and reflected by water. All but the final three lattices are roughly square in shape, and the final three are rectangular. Figure 4.1, generated using KENO 3D, shows a typical Phase 1 model. Case 18 has a rectangular array that is not centered in the tank like the others, but is instead along one side of the tank. The calculated $k_{\text {eff }}$ values, given in Table 4.1, show a correlation to pitch, as shown in Figure 4.2.

The $k_{\text {eff }}$ values for the Phase 1 cases were calculated using SCALE 5.1 with NITAWL resonance processing of the SCALE 238 neutron energy group ENDF/B-V library and with CENTRM/PMC crosssection processing of the SCALE 238 group ENDF/B-VI library. The $k_{\text {eff }}$ values from the NITAWL calculations were on average $0.23 \% \Delta \mathrm{k}_{\text {eff }}$ or 16 standard deviations higher than the $k_{\text {eff }}$ values calculated using CENTRM/PMC, with a maximum difference in $k_{\text {eff }}$ of $0.296 \% \Delta k_{\text {eff. }}$ The correlation to pitch is still evident in the CENTRM/PMC results, and the magnitude of the correlation is similar to the NITAWL results.

Reference 1 provides results of calculations using the French codes APOLLO and MORET. These results are also given in Table 4.1 and Figure 4.2 for comparison with the SCALE results. The correlation of calculated $k_{\text {eff }}$ values to pitch is less evident in the French results than in either of the SCALE results. 


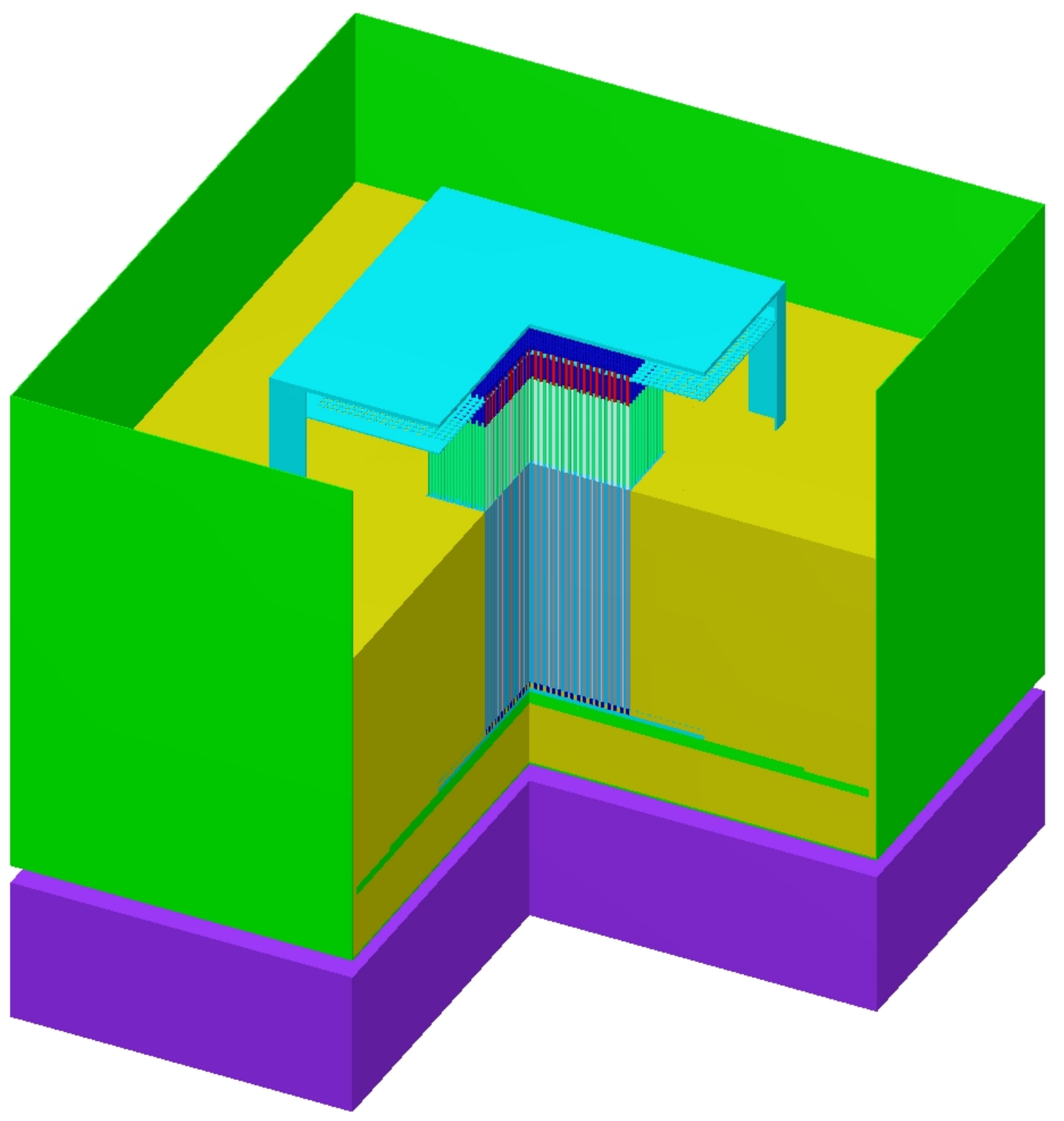

Figure 4.1 KENO-3D representation of a Phase 1 critical configuration with a quadrant removed 
Table 4.1 Calculated $\boldsymbol{k}_{\text {eff }}$ values for Phase 1 experiments

\begin{tabular}{|c|c|cc|cc|cc|}
\hline & \multirow{2}{*}{$\begin{array}{c}\text { Pin } \\
\text { Case }\end{array}$} & $\begin{array}{c}\text { pitch } \\
\text { SCALE 5.1 }\end{array}$ & \multicolumn{2}{c|}{$\begin{array}{c}\text { NITAWL } \\
\text { ENDF/B-V }\end{array}$} & \multicolumn{2}{c|}{$\begin{array}{c}\text { SCALE 5.1 } \\
\text { CENTRM } \\
\text { ENDF/B-VI }\end{array}$} & \multicolumn{2}{|c|}{$\begin{array}{c}\text { APOLLO 2.5.5 } \\
\text { MORET 4.B.3 } \\
\text { CEA93 V6 (Ref. 1) }\end{array}$} \\
\cline { 3 - 8 } & & $\boldsymbol{k}_{\text {eff }}$ & $\boldsymbol{\sigma}$ & \multicolumn{2}{|c|}{$\boldsymbol{k}_{\text {eff }}$} & $\boldsymbol{\sigma}$ & \multicolumn{2}{|c|}{$\boldsymbol{k}_{\text {eff }}$} & $\boldsymbol{\sigma}$ \\
\hline 1 & 2.3 & 1.00035 & 0.00014 & 0.99757 & 0.00013 & 0.99941 & 0.00015 \\
2 & 2.3 & 1.00032 & 0.00013 & 0.99736 & 0.00014 & 0.99838 & 0.00015 \\
3 & 2.3 & 1.00046 & 0.00012 & 0.99752 & 0.00015 & 0.99869 & 0.00015 \\
4 & 1.9 & 0.99966 & 0.00014 & 0.99709 & 0.00014 & 1.00094 & 0.00015 \\
5 & 1.9 & 0.99952 & 0.00014 & 0.99698 & 0.00016 & 1.00072 & 0.00015 \\
6 & 1.9 & 0.99878 & 0.00014 & 0.99667 & 0.00016 & 1.00050 & 0.00015 \\
7 & 1.7 & 0.99866 & 0.00015 & 0.99602 & 0.00015 & 1.00113 & 0.00015 \\
8 & 1.7 & 0.99809 & 0.00015 & 0.99609 & 0.00015 & 1.00075 & 0.00015 \\
9 & 1.7 & 0.99813 & 0.00014 & 0.99576 & 0.00014 & 0.99994 & 0.00015 \\
10 & 1.5 & 0.99669 & 0.00015 & 0.99484 & 0.00016 & 1.00071 & 0.00015 \\
11 & 1.5 & 0.99621 & 0.00016 & 0.99396 & 0.00015 & 0.99984 & 0.00015 \\
12 & 1.5 & 0.99624 & 0.00015 & 0.99388 & 0.00016 & 0.99945 & 0.00015 \\
13 & 1.3 & 0.99366 & 0.00016 & 0.99203 & 0.00015 & 0.99890 & 0.00015 \\
14 & 1.3 & 0.99343 & 0.00015 & 0.99164 & 0.00016 & 0.99741 & 0.00015 \\
15 & 1.3 & 0.99327 & 0.00016 & 0.99128 & 0.00016 & 0.99708 & 0.00015 \\
16 & 1.7 & 0.99812 & 0.00015 & 0.99581 & 0.00015 & 1.00055 & 0.00015 \\
17 & 1.7 & 0.99806 & 0.00015 & 0.99548 & 0.00015 & 1.00011 & 0.00015 \\
18 & 1.7 & 0.99549 & 0.00015 & 0.99315 & 0.00015 & 0.99778 & 0.00015 \\
\hline
\end{tabular}




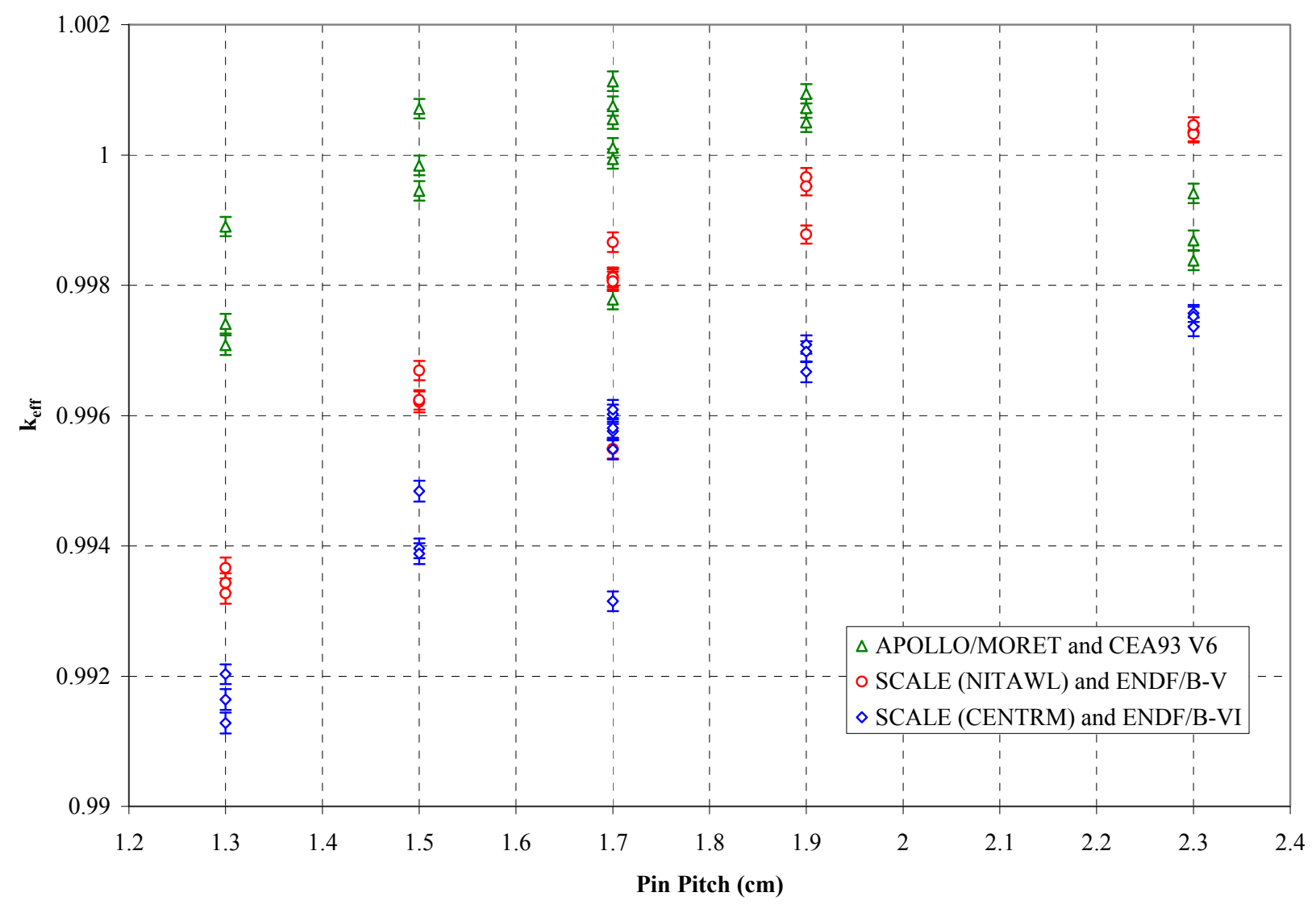

Figure 4.2 Phase 1 calculated $k_{\text {eff }}$ as a function of fuel rod pitch

\subsection{Results for Phase 2 Experiments}

This group of experiments consists of lattices of varying size and pitch, moderated by water with varying concentrations of either gadolinium or boron. Most of the lattices are roughly square in shape, but some are rectangular. The Phase 2 models are similar to the Phase 1 model shown in Figure 4.1. The Phase 2 cases were calculated using SCALE 5.1 with NITAWL resonance processing of the SCALE 238 neutron energy group ENDF/B-V library and with the CENTRM/PMC cross-section processing of the SCALE 238 group ENDF/B-VI library. The calculated results are shown in Tables 4.2 and 4.3. The calculated $k_{\text {eff }}$ values show a correlation to pitch for each group of experiments, as shown in Figures 4.3 and 4.5. Figures 4.4 and 4.6 show the calculated $k_{\text {eff }}$ values as a function of gadolinium and boron concentration, respectively. The soluble boron $1.3-\mathrm{cm}$ pitch data shows a trend of increasing calculated $k_{\text {eff }}$ with increasing soluble boron concentration. This trend is not as evident for the other pin pitches. If a boron concentration dependent bias does exist, one would expect to see it in the data for the other pin pitches. No obvious trends with gadolinium concentration were noted. Reference 2 provides results of calculations using the French codes APOLLO and MORET. These results are also given in Tables 4.2 and 4.3 and Figures 4.3 and 4.5 for comparison with the SCALE results. The correlation of calculated $k_{\text {eff }}$ values to pitch is present in the French results to the same degree that it is found in the SCALE results. On average, the French results are higher than either the SCALE/NITAWL or the SCALE/CENTRM results. 
One interesting observation can be made from Figure 4.5 is that the $k_{\text {eff }}$ values for soluble boron cases 18 , 20 and 21 are significantly lower than what would be expected based on the trend in the figure. From a review of the data in Table 2 of the Phase 2 report, the only obvious connection between these three cases is that they were the last three configurations in the series and were performed after a delay of 19 days. Soluble boron case 18 is a $1.7-\mathrm{cm}$ pitch experiment that is similar to the other $1.7-\mathrm{cm}$ pitch experiments, which, except for case 18 , do follow a trend of increasing calculated $k_{\text {eff }}$ with increasing pitch.

Table 4.2 Calculated $\boldsymbol{k}_{\text {eff }}$ values for Phase 2 experiments with gadolinium

\begin{tabular}{|c|c|c|c|c|c|c|c|}
\hline \multirow[t]{2}{*}{ Case } & \multirow{2}{*}{$\begin{array}{l}\text { Pin } \\
\text { pitch } \\
\text { (cm) }\end{array}$} & \multicolumn{2}{|c|}{$\begin{array}{l}\text { SCALE } 5.1 \\
\text { NITAWL } \\
\text { ENDF/B-V }\end{array}$} & \multicolumn{2}{|c|}{$\begin{array}{c}\text { SCALE 5.1 } \\
\text { CENTRM } \\
\text { ENDF/B-VI }\end{array}$} & \multicolumn{2}{|c|}{$\begin{array}{c}\text { APOLLO 2.5.5 } \\
\text { MORET4.B.3 } \\
\text { CEA93 V6 (Ref. 2) }\end{array}$} \\
\hline & & $k_{\text {eff }}$ & $\sigma$ & $k_{\text {eff }}$ & $\boldsymbol{\sigma}$ & $k_{\text {eff }}$ & $\boldsymbol{\sigma}$ \\
\hline 1 & 1.3 & 0.99485 & 0.00015 & 0.99236 & 0.00015 & 0.99855 & 0.00015 \\
\hline 2 & 1.3 & 0.99440 & 0.00015 & 0.99242 & 0.00014 & 0.99791 & 0.00015 \\
\hline 3 & 1.3 & 0.99481 & 0.00015 & 0.99236 & 0.00015 & 0.99905 & 0.00015 \\
\hline 4 & 1.3 & 0.99533 & 0.00014 & 0.99261 & 0.00014 & 0.99901 & 0.00015 \\
\hline 5 & 1.3 & 0.99506 & 0.00015 & 0.99249 & 0.00015 & 0.99881 & 0.00015 \\
\hline 6 & 1.3 & 0.99485 & 0.00015 & 0.99200 & 0.00015 & 0.99919 & 0.00015 \\
\hline 7 & 1.3 & 0.99481 & 0.00014 & 0.99210 & 0.00015 & 0.99881 & 0.00015 \\
\hline 8 & 1.3 & 0.99466 & 0.00014 & 0.99151 & 0.00016 & 0.99886 & 0.00015 \\
\hline 9 & 1.3 & 0.99505 & 0.00016 & 0.99174 & 0.00015 & 0.99894 & 0.00015 \\
\hline 10 & 1.5 & 0.99813 & 0.00013 & 0.99377 & 0.00013 & 0.99995 & 0.00015 \\
\hline 11 & 1.5 & 0.99835 & 0.00014 & 0.99462 & 0.00015 & 1.00165 & 0.00015 \\
\hline 12 & 1.5 & 0.99859 & 0.00015 & 0.99476 & 0.00013 & 1.00094 & 0.00015 \\
\hline 13 & 1.5 & 0.99812 & 0.00015 & 0.99481 & 0.00014 & 1.00183 & 0.00015 \\
\hline 14 & 1.5 & 0.99819 & 0.00014 & 0.99494 & 0.00015 & 1.00197 & 0.00015 \\
\hline 15 & 1.5 & 0.99865 & 0.00015 & 0.99585 & 0.00015 & 1.00273 & 0.00015 \\
\hline 16 & 1.5 & 0.99866 & 0.00016 & 0.99602 & 0.00015 & 1.00220 & 0.00015 \\
\hline 17 & 1.7 & 1.00076 & 0.00014 & 0.99754 & 0.00014 & 1.00340 & 0.00015 \\
\hline 18 & 1.9 & 1.00206 & 0.00013 & 0.99871 & 0.00013 & 1.00312 & 0.00015 \\
\hline 19 & 1.7 & 0.99845 & 0.00014 & 0.99464 & 0.00014 & 1.00222 & 0.00015 \\
\hline 20 & 1.7 & 1.00045 & 0.00014 & 0.99740 & 0.00014 & 1.00306 & 0.00015 \\
\hline
\end{tabular}




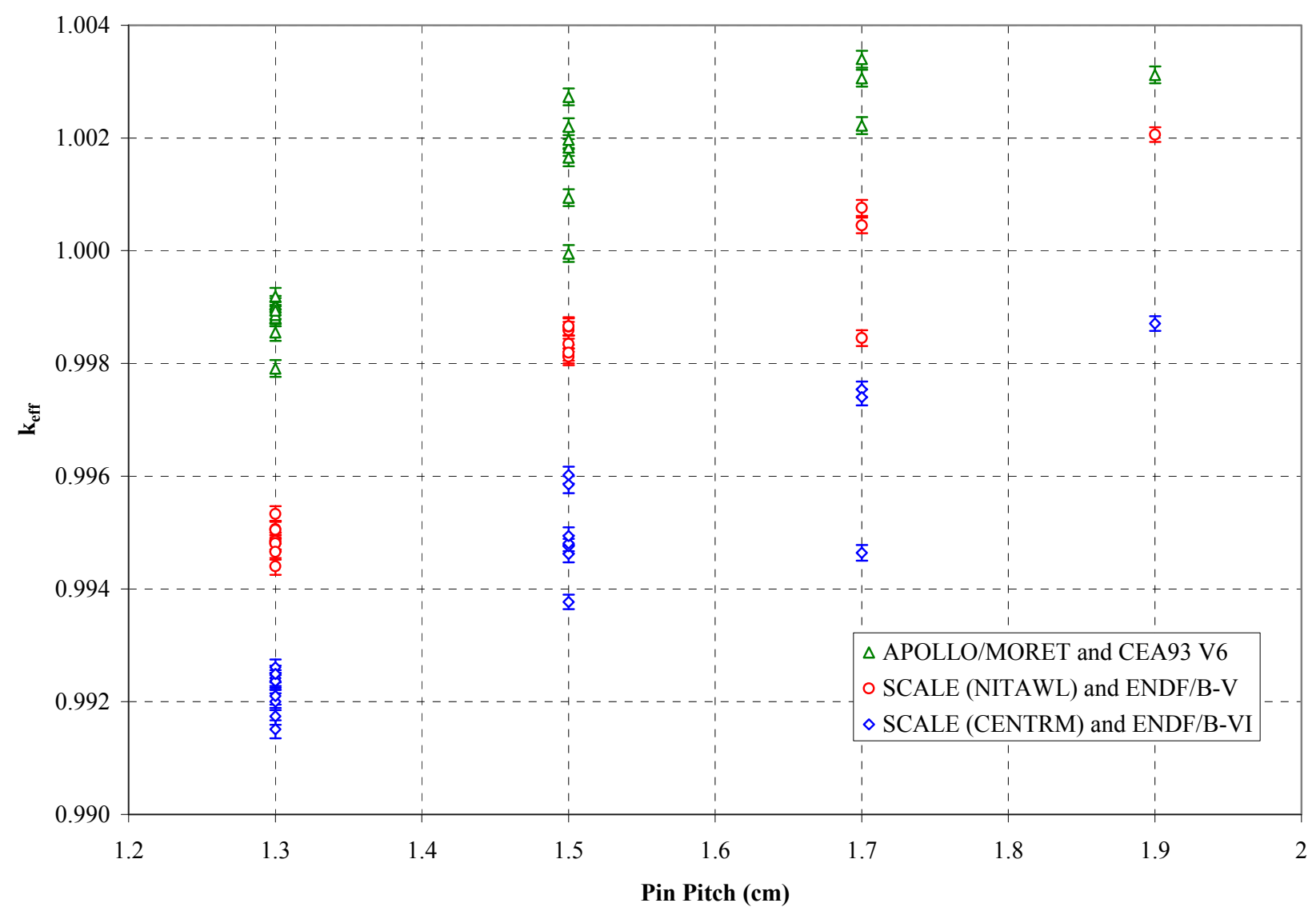

Figure 4.3 Calculated $\boldsymbol{k}_{\text {eff }}$ values vs pin pitch for Phase 2 gadolinium experiments 


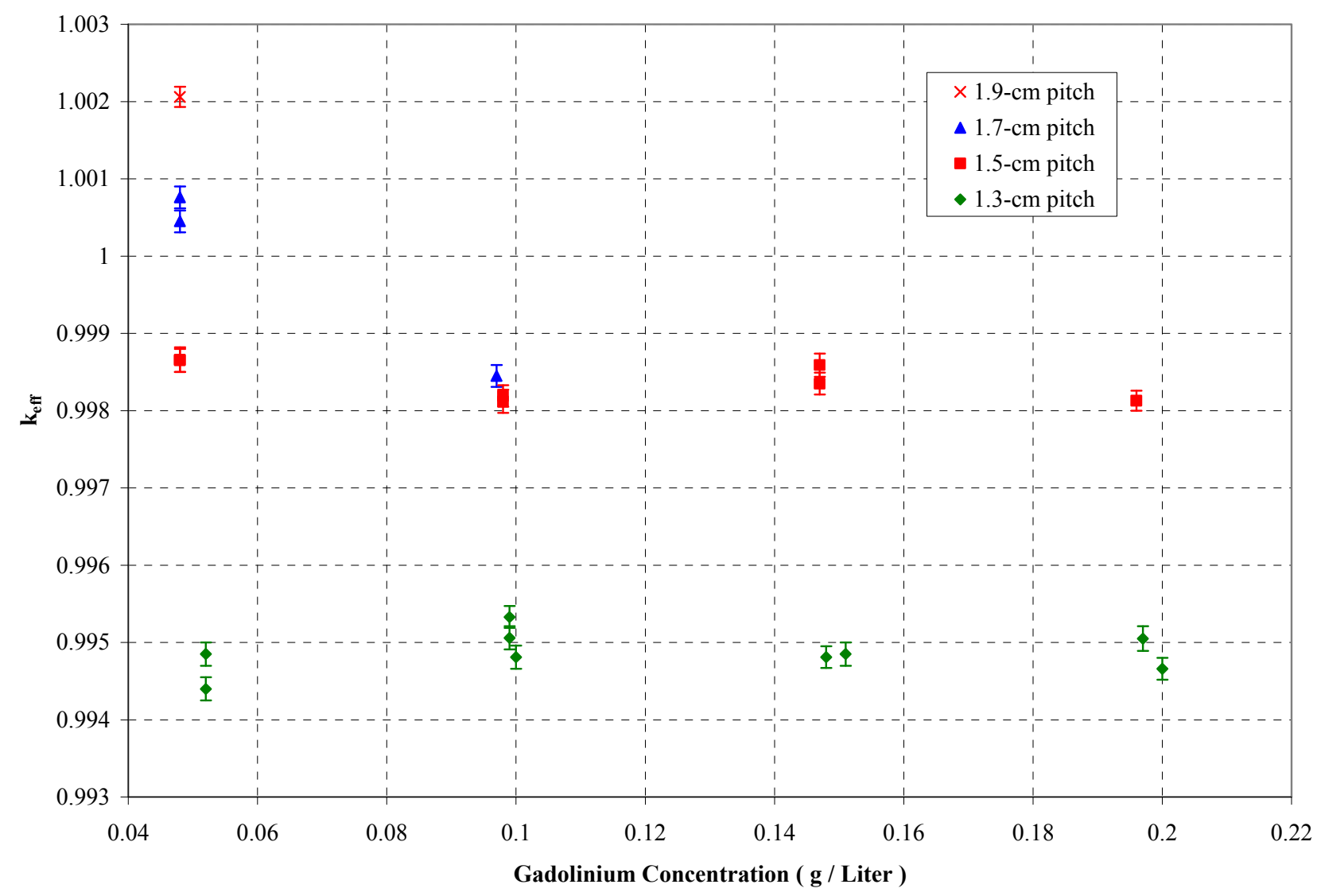

Figure 4.4 Calculated $\boldsymbol{k}_{\text {eff }}$ values vs gadolinium concentration for Phase 2 gadolinium experiments (SCALE NITAWL results) 
Table 4.3 Calculated $\boldsymbol{k}_{\text {eff }}$ values for Phase 2 experiments with boron

\begin{tabular}{|c|c|c|c|c|c|c|c|}
\hline \multirow[t]{2}{*}{ Case } & \multirow{2}{*}{$\begin{array}{l}\text { Pin } \\
\text { pitch } \\
\text { (cm) }\end{array}$} & \multicolumn{2}{|c|}{$\begin{array}{l}\text { SCALE } 5.1 \\
\text { NITAWL } \\
\text { ENDF/B-V }\end{array}$} & \multicolumn{2}{|c|}{$\begin{array}{c}\text { SCALE 5.1 } \\
\text { CENTRM } \\
\text { ENDF/B-VI }\end{array}$} & \multicolumn{2}{|c|}{$\begin{array}{c}\text { APOLLO 2.5.5 } \\
\text { MORET4.B.3 } \\
\text { CEA93 V6 (Ref. 2) }\end{array}$} \\
\hline & & $k_{\text {eff }}$ & $\sigma$ & $k_{\text {eff }}$ & $\boldsymbol{\sigma}$ & $\boldsymbol{k}_{\text {eff }}$ & $\boldsymbol{\sigma}$ \\
\hline 1 & 1.3 & 0.99466 & 0.00020 & 0.99269 & 0.00017 & 0.99863 & 0.00015 \\
\hline 2 & 1.3 & 0.99356 & 0.00016 & 0.99160 & 0.00016 & 0.99747 & 0.00015 \\
\hline 3 & 1.3 & 0.99387 & 0.00015 & 0.99216 & 0.00015 & 0.99840 & 0.00015 \\
\hline 4 & 1.3 & 0.99561 & 0.00016 & 0.99331 & 0.00016 & 0.99934 & 0.00015 \\
\hline 5 & 1.3 & 0.99519 & 0.00015 & 0.99336 & 0.00015 & 0.99886 & 0.00015 \\
\hline 6 & 1.3 & 0.99536 & 0.00015 & 0.99348 & 0.00016 & 0.99943 & 0.00015 \\
\hline 7 & 1.3 & 0.99650 & 0.00015 & 0.99468 & 0.00015 & 1.00024 & 0.00015 \\
\hline 8 & 1.3 & 0.99600 & 0.00014 & 0.99398 & 0.00014 & 0.99985 & 0.00015 \\
\hline 9 & 1.5 & 0.99854 & 0.00013 & 0.99599 & 0.00014 & 1.00104 & 0.00015 \\
\hline 10 & 1.5 & 0.99688 & 0.00014 & 0.99417 & 0.00015 & 0.99967 & 0.00015 \\
\hline 11 & 1.5 & 0.99842 & 0.00014 & 0.99605 & 0.00015 & 1.00192 & 0.00015 \\
\hline 12 & 1.5 & 0.99843 & 0.00015 & 0.99581 & 0.00014 & 1.00136 & 0.00015 \\
\hline 13 & 1.5 & 0.99695 & 0.00015 & 0.99482 & 0.00016 & 1.00020 & 0.00015 \\
\hline 14 & 1.5 & 0.99959 & 0.00016 & 0.99749 & 0.00016 & 1.00336 & 0.00015 \\
\hline 15 & 1.7 & 1.00231 & 0.00014 & 0.99981 & 0.00014 & 1.00449 & 0.00015 \\
\hline 16 & 1.7 & 1.00104 & 0.00014 & 0.99845 & 0.00013 & 1.00304 & 0.00015 \\
\hline 17 & 1.7 & 1.00265 & 0.00014 & 1.00045 & 0.00014 & 1.00416 & 0.00015 \\
\hline 18 & 1.7 & 0.99378 & 0.00014 & 0.99126 & 0.00013 & 0.99534 & 0.00015 \\
\hline 19 & 1.7 & 0.99948 & 0.00014 & 0.99671 & 0.00014 & 1.00161 & 0.00015 \\
\hline 20 & 1.9 & 0.99331 & 0.00013 & 0.99057 & 0.00013 & 0.99343 & 0.00015 \\
\hline 21 & 1.9 & 0.99692 & 0.00013 & 0.99429 & 0.00013 & 0.99750 & 0.00015 \\
\hline
\end{tabular}




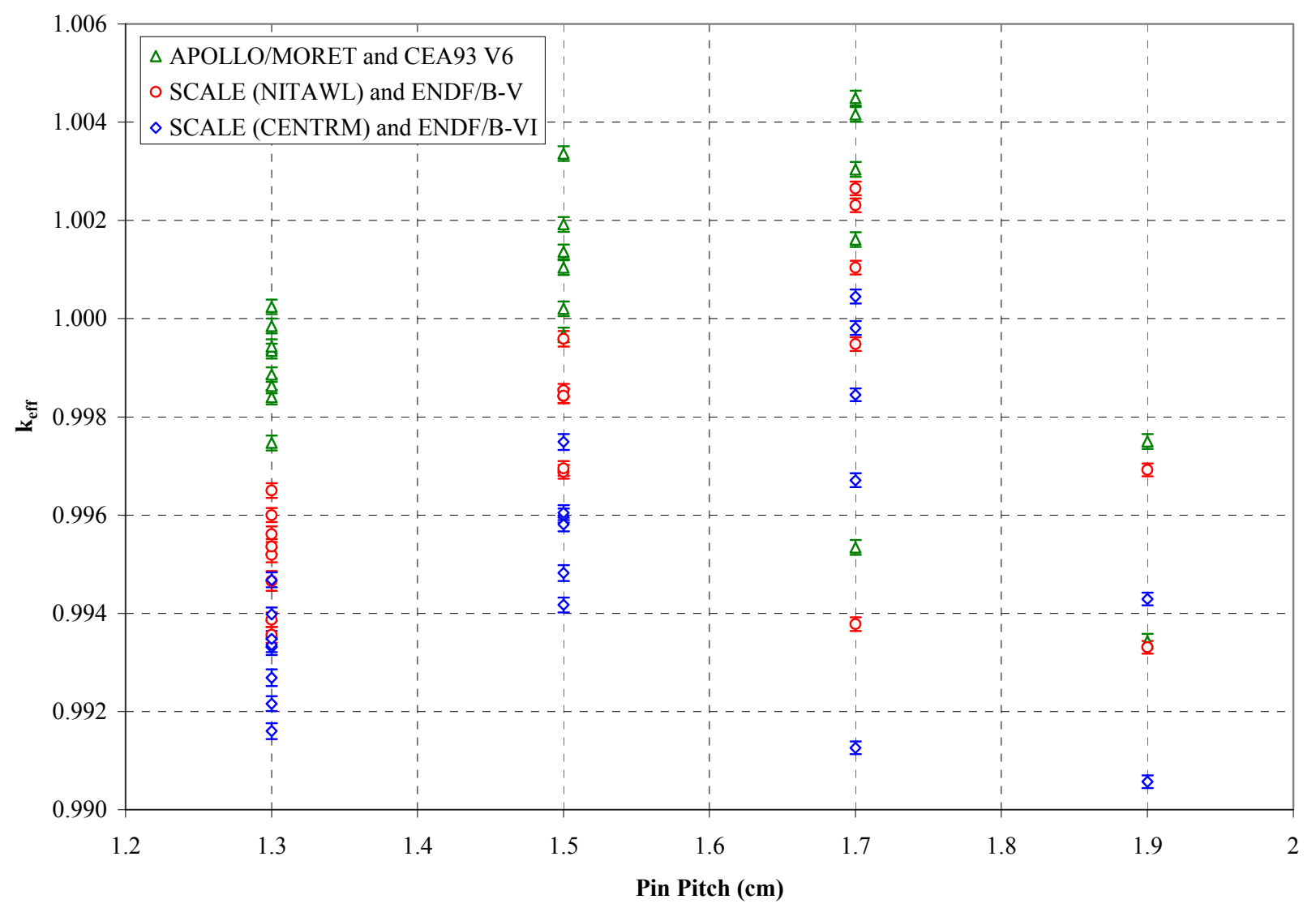

Figure 4.5 Calculated $\boldsymbol{k}_{\text {eff }}$ values vs pin pitch for Phase 2 boron experiments 


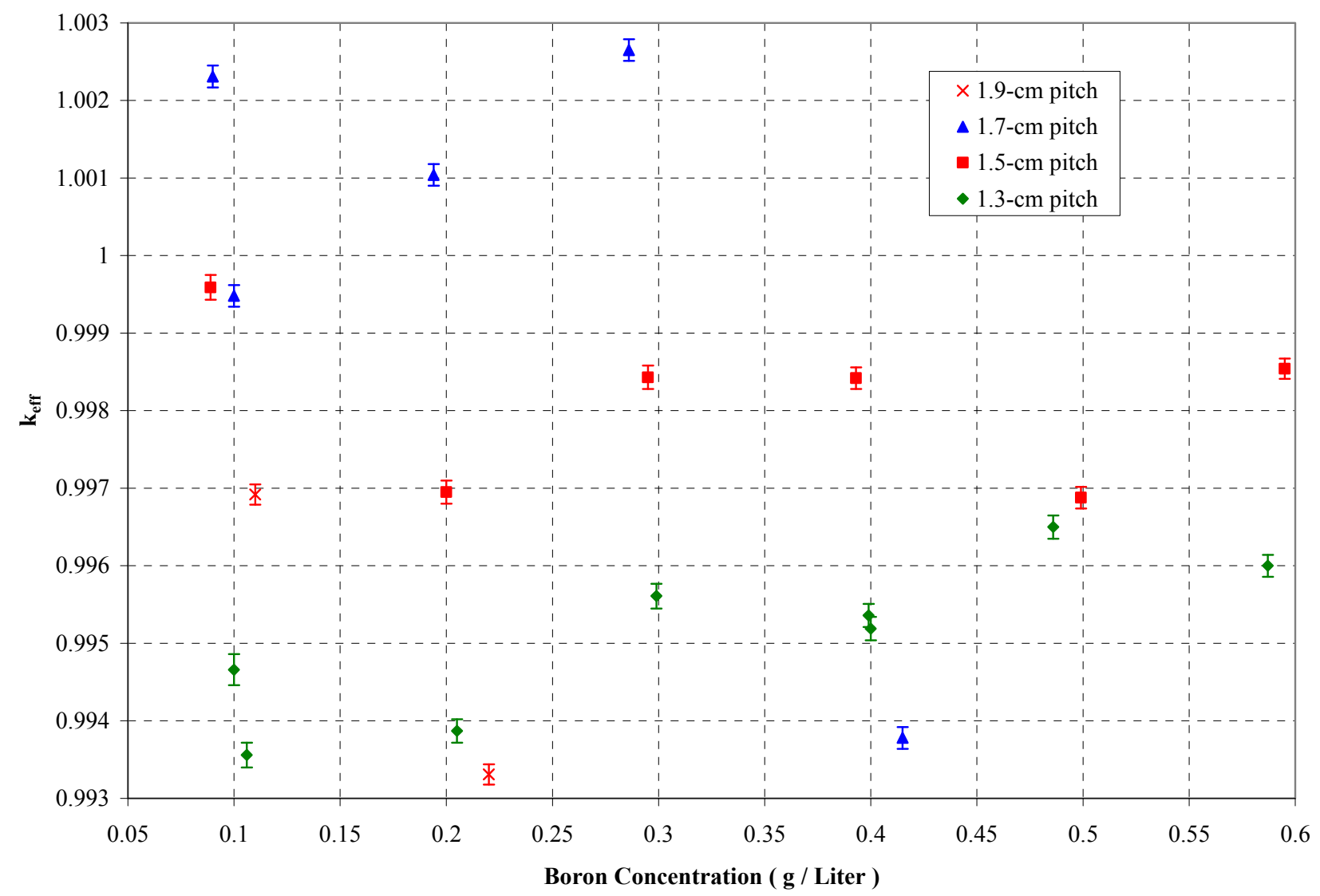

Figure 4.6 Calculated $\boldsymbol{k}_{\text {eff }}$ values vs boron concentration for Phase 2 boron experiments (results using SCALE CSAS25 with NITAWL cross section processing)

\subsection{Results for Phase 3 Experiments}

This group of experiments simulates four fuel assemblies of varied array sizes in a tank of water. The assemblies are separated by a varying thickness of water, and some have a canister of neutron-absorbing material around the outside of each assembly. The neutron-absorbing panels were one of the following: B-SS plates, steel clad cadmium, or aluminum clad $\mathrm{B}_{4} \mathrm{C}+\mathrm{Al}$ mixture $\left(\right.$ Boral $\left.^{\circledR}\right)$. All lattices had 1.6-cm fuel pin-pitch spacing. Figure Figure 4.7 is a three-dimensional (3-D) KENO representation of one of the configurations that had poison panels. Note that symmetry was used to reduce the model to a single assembly. The two "bare" lateral faces have a reflective boundary condition in the KENO model. The calculated $k_{\text {eff }}$ values for this group of experiments are given in Table 4.4.

The $k_{\text {eff }}$ values for the Phase 3 cases were calculated using SCALE 5.1 with NITAWL resonance processing of the SCALE 238 neutron energy group ENDF/B-V library and with CENTRM/PMC crosssection processing of the SCALE 238 group ENDF/B-VI library. The $k_{\text {eff }}$ values from the NITAWL calculations were on average $0.20 \% \Delta k_{\text {eff }}$ or 14 standard deviations higher than the $k_{\text {eff }}$ values calculated using CENTRM/PMC, with a maximum difference in $k_{\text {eff }}$ of $0.31 \% \Delta k_{\text {eff. }}$

Reference 3 provides results of calculations using the French codes APOLLO and MORET. These results are also given in Table 4.4 for comparison with the SCALE results. In most cases, the French results are higher than those calculated using SCALE. 
A few trends are noted in the calculated results for all three code combinations, as shown in Figure 4.8. The results for Cases 2 and 8 are higher than for other cases within each canister group. Case 6 also calculates somewhat higher than the overall average but is the only case with a Boral ${ }^{\mathbb{B}}$ canister. All three of these experiments do not have any water gap separating the canister walls of adjacent assemblies. Cases 23 and 24 also do not have a water gap, but they do not have canister plates surrounding each simulated assembly. These two cases with no water gap do not calculate significantly different from other cases in their group, which do have water gaps.

On average, the calculated results for cases 7-11, the cadmium canisters, are lower than for the other canister groupings. This is particularly true if Case 8 is not included in the average results. The results may indicate that an additional bias should be applied to calculations that include cadmium. The lower $k_{\text {eff }}$ values could be due to one or more of the following:

- Incorrect description (e.g., dimensions and/or composition) of the $\mathrm{Cd}$ in the experiments

- Incorrect measurements of the $\mathrm{Cd}$ cross sections

- Incorrect evaluation of the measured Cd cross sections

Figure 4.9 shows calculated $k_{\text {eff }}$ values for the cases that have poison panels as a function of spacing between the assemblies. Note that for both the B-SS and cadmium panel types and for both SCALE and APOLLO/MORET, the zero spacing results are significantly higher than the $k_{\text {eff }}$ values calculated for the cases with space between the assemblies. This probably indicates that there was some small water-filled space between the poison panels around each assembly. Calculations showed that introduction of a 2-mm gap between the assemblies with cadmium panels reduced $k_{\text {eff }}$ from $0.99917 \pm 0.00014$ to $0.99467 \pm$ 0.00014. It is recommended that the poison panel cases with zero water gap between assemblies not be used until/unless these differences are better understood. Figure 4.10 shows the calculated $k_{\text {eff }}$ values for the Phase 3 experiments without poison panels. No significant trends are observed in these results. 


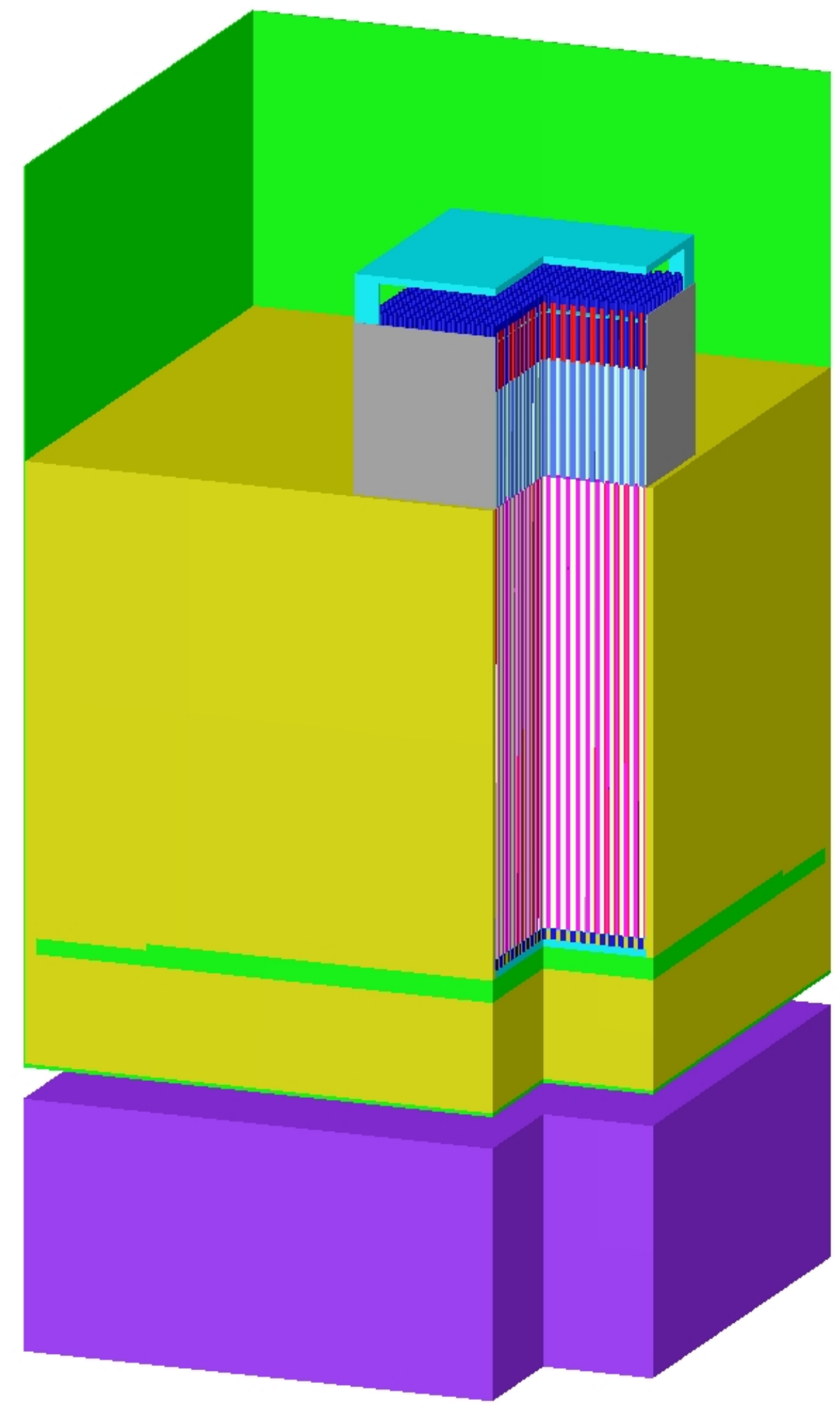

Figure 4.7 KENO-3D representation of a Phase 3 critical configuration with a section removed 
Table 4.4 Calculated $\boldsymbol{k}_{\text {eff }}$ values for Phase 3 experiments

\begin{tabular}{|c|c|c|c|c|c|c|c|}
\hline \multirow[t]{2}{*}{ Case } & \multirow[t]{2}{*}{$\begin{array}{c}\text { Poison } \\
\text { Plate }\end{array}$} & \multicolumn{2}{|c|}{$\begin{array}{l}\text { SCALE } 5.1 \\
\text { NITAWL } \\
\text { ENDF/B-V }\end{array}$} & \multicolumn{2}{|c|}{$\begin{array}{c}\text { SCALE 5.1 } \\
\text { CENTRM } \\
\text { ENDF/B-VI }\end{array}$} & \multicolumn{2}{|c|}{$\begin{array}{c}\text { APOLLO 2.5.5 } \\
\text { MORET4.B.3 } \\
\text { CEA93 V6 (Ref. 3) }\end{array}$} \\
\hline & & $k_{\text {eff }}$ & $\boldsymbol{\sigma}$ & $\boldsymbol{k}_{\text {eff }}$ & $\sigma$ & $\boldsymbol{k}_{\text {eff }}$ & $\boldsymbol{\sigma}$ \\
\hline 1 & B-SS & 0.99627 & 0.00014 & 0.99428 & 0.00014 & 0.99963 & 0.00015 \\
\hline 2 & B-SS & 0.99855 & 0.00014 & 0.99673 & 0.00015 & 1.00366 & 0.00015 \\
\hline 3 & B-SS & 0.99580 & 0.00015 & 0.99413 & 0.00014 & 1.00012 & 0.00015 \\
\hline 4 & B-SS & 0.99552 & 0.00015 & 0.99370 & 0.00015 & 0.99918 & 0.00015 \\
\hline 5 & B-SS & 0.99557 & 0.00014 & 0.99389 & 0.00014 & 0.99992 & 0.00015 \\
\hline 6 & Boral $^{\circledR}$ & 0.99800 & 0.00015 & 0.99686 & 0.00014 & 1.00262 & 0.00015 \\
\hline 7 & $\mathrm{Cd}$ & 0.99364 & 0.00016 & 0.99185 & 0.00014 & 0.99874 & 0.00015 \\
\hline 8 & $\mathrm{Cd}$ & 0.99993 & 0.00015 & 0.99884 & 0.00015 & 1.00540 & 0.00015 \\
\hline 9 & $\mathrm{Cd}$ & 0.99329 & 0.00015 & 0.99223 & 0.00015 & 0.99851 & 0.00015 \\
\hline 10 & $\mathrm{Cd}$ & 0.99368 & 0.00014 & 0.99263 & 0.00015 & 0.99930 & 0.00015 \\
\hline 11 & $\mathrm{Cd}$ & 0.99290 & 0.00014 & 0.99178 & 0.00015 & 0.99833 & 0.00015 \\
\hline 12 & None & 0.99715 & 0.00015 & 0.99493 & 0.00015 & 0.99956 & 0.00015 \\
\hline 13 & None & 0.99728 & 0.00014 & 0.99484 & 0.00014 & 0.99927 & 0.00015 \\
\hline 14 & None & 0.99754 & 0.00015 & 0.99480 & 0.00015 & 0.99980 & 0.00015 \\
\hline 15 & None & 0.99743 & 0.00014 & 0.99473 & 0.00014 & 0.99801 & 0.00015 \\
\hline 16 & None & 0.99734 & 0.00014 & 0.99516 & 0.00015 & 0.99899 & 0.00015 \\
\hline 17 & None & 0.99766 & 0.00015 & 0.99500 & 0.00015 & 0.99880 & 0.00015 \\
\hline 18 & None & 0.99757 & 0.00015 & 0.99495 & 0.00014 & 0.99824 & 0.00015 \\
\hline 19 & None & 0.99886 & 0.00014 & 0.99589 & 0.00014 & 0.99778 & 0.00015 \\
\hline 20 & None & 0.99872 & 0.00015 & 0.99564 & 0.00015 & 0.99707 & 0.00015 \\
\hline 21 & None & 0.99844 & 0.00015 & 0.99601 & 0.00014 & 0.99792 & 0.00015 \\
\hline 22 & None & 0.99859 & 0.00014 & 0.99615 & 0.00015 & 0.99968 & 0.00015 \\
\hline 23 & None & 0.99678 & 0.00015 & 0.99497 & 0.00016 & 0.99964 & 0.00015 \\
\hline 24 & None & 0.99768 & 0.00016 & 0.99553 & 0.00016 & 1.00393 & 0.00015 \\
\hline 25 & None & 0.99792 & 0.00015 & 0.99558 & 0.00014 & 1.00111 & 0.00015 \\
\hline 26 & None & 0.99709 & 0.00014 & 0.99493 & 0.00016 & 0.99943 & 0.00015 \\
\hline
\end{tabular}




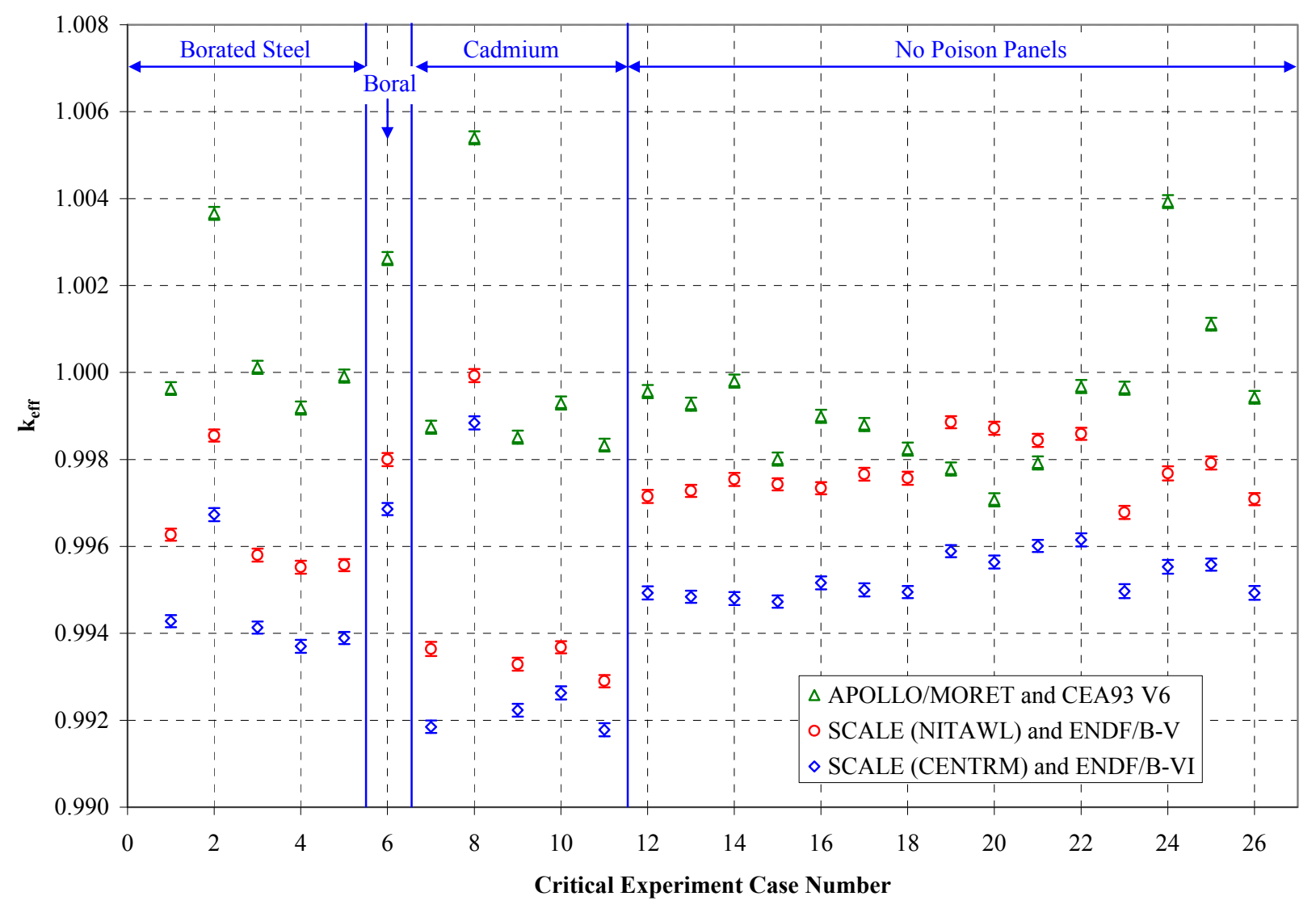

Figure 4.8 Phase 3 experiment results 


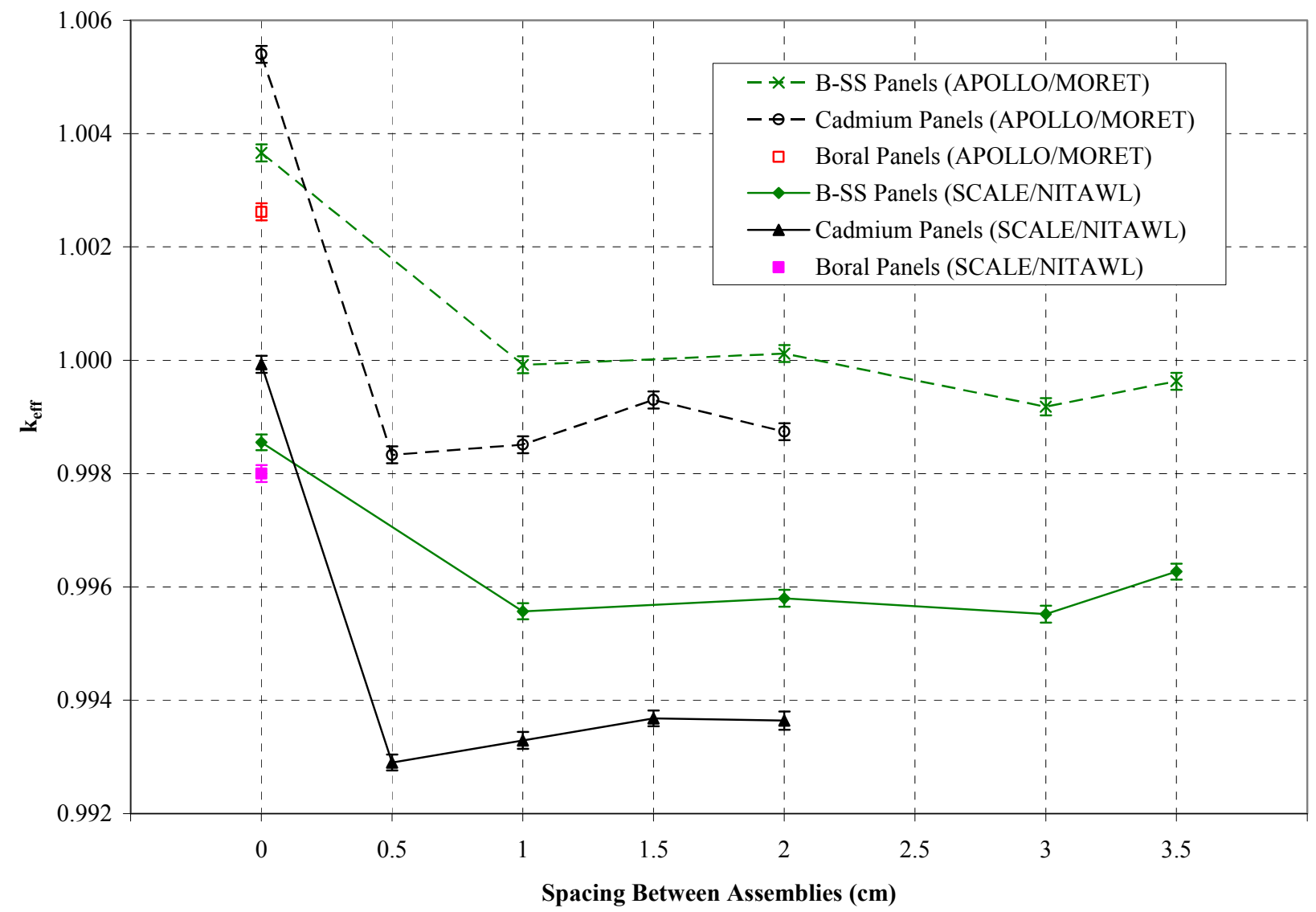

Figure 4.9 Calculated $\boldsymbol{k}_{\text {eff }}$ values for Phase 3 experiments having absorber panels as a function of spacing between assemblies 


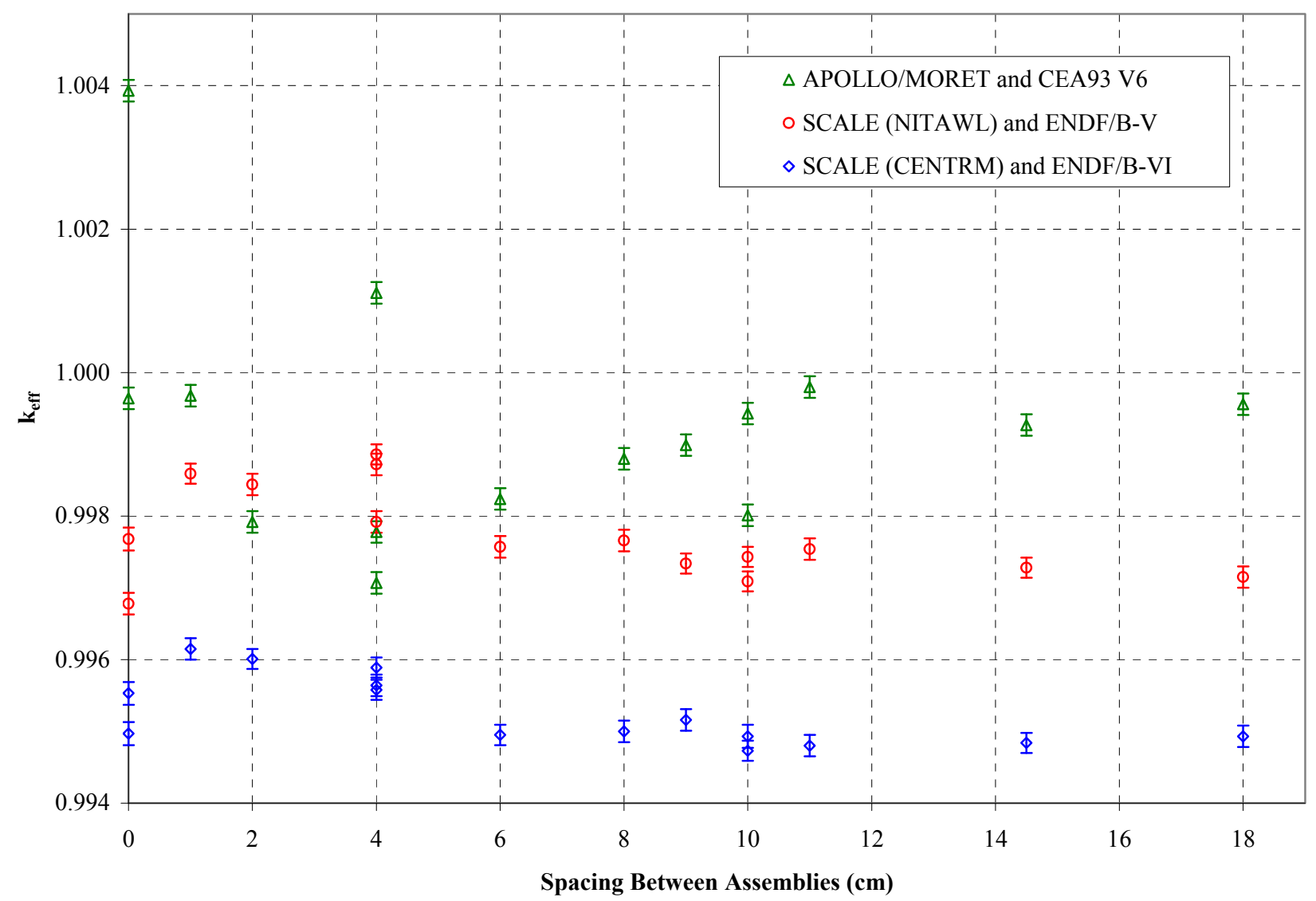

Figure 4.10 Calculated $\boldsymbol{k}_{\text {eff }}$ values for Phase 3 experiment without absorber panels as a function of spacing between assemblies

\subsection{Results for Phase 4 Experiments}

This group of experiments simulates four fuel_assemblies in a flooded cask-like geometry. The assemblies are separated by a varying thickness of water, and some have a canister of neutron-absorbing material around the outside of each assembly. The group of four assemblies is then surrounded by either a thick steel or lead reflector screen, with a varying thickness of water between the assemblies and the reflector. The neutron-absorbing panels were one of the following: B-SS, steel clad cadmium, or aluminum clad $\mathrm{B}_{4} \mathrm{C}+\mathrm{Al}$ mixture $\left(\right.$ Boral $\left.^{\mathbb{B}}\right)$. All lattices had 1.6-cm fuel pin-pitch spacing. Figure 4.11 shows a KENO-3D representation of one of the models, which had poison panels. As can be seen by comparing Figure 2.1 with Figure 4.11, the SCALE Phase 4 models were simplified by replacing the extra shield material at each corner with water, thus restoring symmetry to the model. 


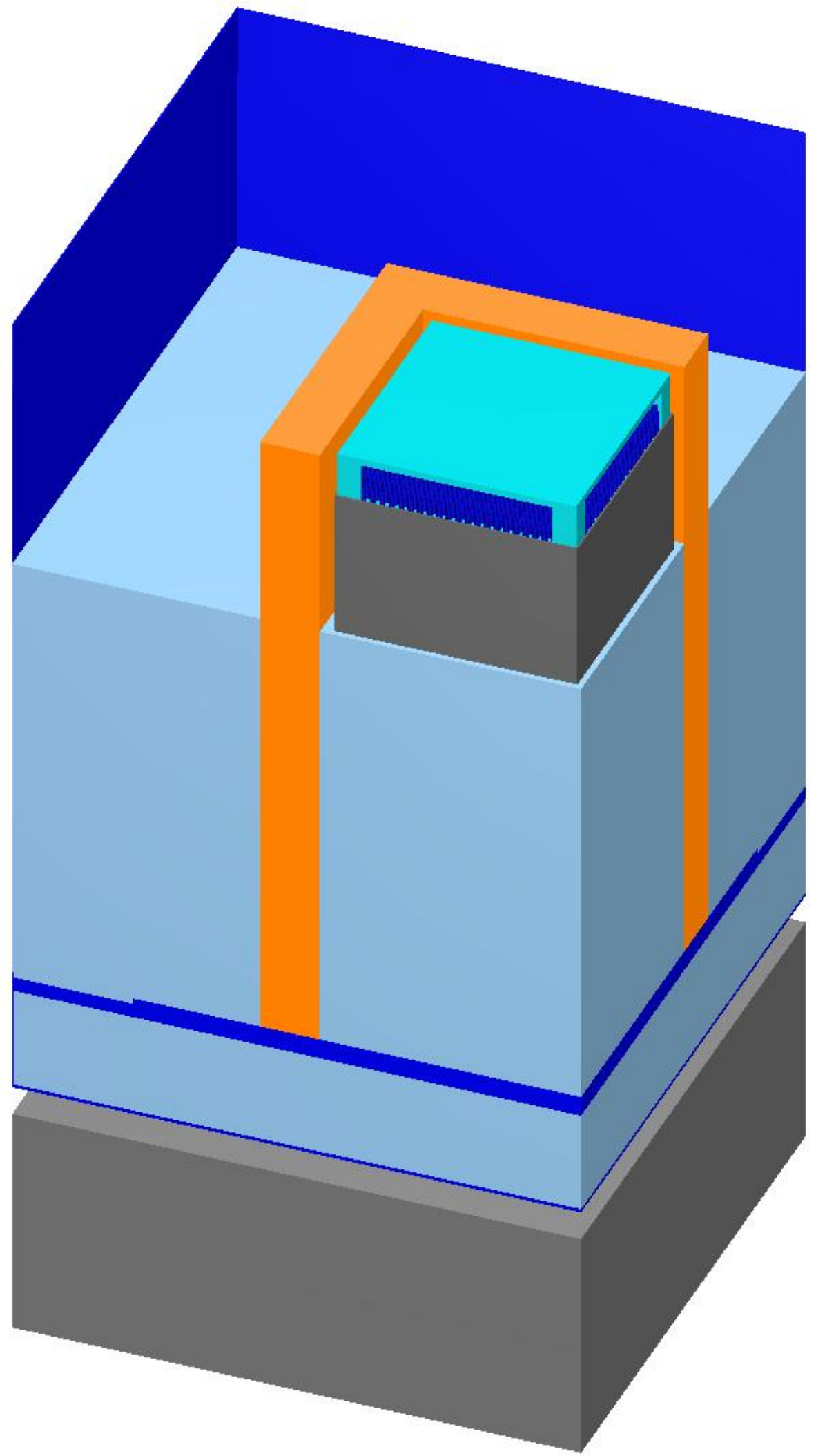

Figure 4.11 KENO-3D representation of a typical Phase 4 experiment 
The calculated results are given in Tables 4.5 and 4.6 and shown in Figures 4.12 through 4.17.

Within each set of experiments using the same reflector (or screen) and the same canister type, there is a series of experiments using an increasing water gap between assemblies. For cases with neutronabsorbing plates on the sides of each assembly, the change from a $0-\mathrm{cm}$ to a $1-\mathrm{cm}$ water gap between assemblies significantly decreases the calculated $k_{\text {eff }}$ for systems that are supposed to have the same $k_{\text {eff }}$ value. Further increases in the water gap thickness have smaller impact on the calculated $k_{\text {eff }}$ values. This is similar to the effect seen in Phase 3, where the experiments with no water gap calculate significantly higher than the others within their canister group. This probably indicates that there was some small water-filled space between the poison panels around each assembly. The uncertainty analyses in the Phase 4 report (Ref. 4) show that the calculated $k_{\text {eff }}$ values are very sensitive to the water between the poison panels. Due to the high calculated $k_{\text {eff }}$ values and the non-conservative direction of the variation, it is recommended that the poison panel cases with zero water gap between assemblies not be used until/unless these differences are better understood.

The Phase 4 experiments without poison panels do not exhibit significant trends in calculated $k_{\text {eff }}$ value as the water gap between assemblies changes. Consequently, there appears to be no additional calculational bias related to the water gap between assemblies that do not have poison panels.

Within some subsets of experiments using the same reflector and the same canister type, there is also a series of experiments using an increasing water gap between the fuel assemblies and the reflector. For cases using neutron-absorbing panels, Figures 4.16 and 4.17 show that there is a trend of decreasing $k_{\text {eff }}$ as this water gap increases. This may indicate an increasingly negative bias in calculated $k_{\text {eff }}$ values as the water gap increases between the reflector and the assemblies. For the two series that use no canister, there is not a significant trend in $k_{\text {eff }}$ with changing assembly-to-shield gap thickness and thus no calculational bias associated with gap thickness. 
Table 4.5 Calculated $\boldsymbol{k}_{\text {eff }}$ values for Phase 4 experiments with steel reflector

\begin{tabular}{|c|c|c|c|c|c|c|c|}
\hline \multirow[t]{2}{*}{ Case } & \multirow[t]{2}{*}{$\begin{array}{c}\text { Poison } \\
\text { plate }\end{array}$} & \multicolumn{2}{|c|}{$\begin{array}{l}\text { SCALE 5.1 } \\
\text { (NITAWL) } \\
\text { ENDF/B-V }\end{array}$} & \multicolumn{2}{|c|}{$\begin{array}{l}\text { SCALE 5.1 } \\
(\text { CENTRM) } \\
\text { ENDF/B-VI }\end{array}$} & \multicolumn{2}{|c|}{$\begin{array}{c}\text { APOLLO2.5.4- } \\
\text { MORET4.B.3 } \\
\text { CEA93 V6 (Ref.4) }\end{array}$} \\
\hline & & $\boldsymbol{k}_{\text {eff }}$ & $\boldsymbol{\sigma}$ & $\boldsymbol{k}_{\text {eff }}$ & $\boldsymbol{\sigma}$ & $\boldsymbol{k}_{\text {eff }}$ & $\boldsymbol{\sigma}$ \\
\hline 1 & B-SS & 1.00108 & 0.00014 & 0.99969 & 0.00014 & 1.00896 & 0.00015 \\
\hline 2 & B-SS & 0.99780 & 0.00015 & 0.99630 & 0.00014 & 1.00551 & 0.00015 \\
\hline 3 & B-SS & 0.99773 & 0.00014 & 0.99589 & 0.00014 & 1.00515 & 0.00015 \\
\hline 4 & B-SS & 0.99749 & 0.00014 & 0.99557 & 0.00016 & 1.00482 & 0.00015 \\
\hline 5 & B-SS & 0.99728 & 0.00015 & 0.99572 & 0.00015 & 1.00446 & 0.00015 \\
\hline 6 & B-SS & 0.99633 & 0.00014 & 0.99436 & 0.00015 & 1.00259 & 0.00015 \\
\hline 7 & B-SS & 0.99547 & 0.00014 & 0.99372 & 0.00014 & 1.00120 & 0.00015 \\
\hline 8 & B-SS & 0.99528 & 0.00014 & 0.99354 & 0.00015 & 1.00 & 0.00015 \\
\hline 9 & B-SS & 0.99471 & 0.00015 & 0.99299 & 0.00015 & 1.00028 & 0.00015 \\
\hline 10 & B-SS & 0.99743 & 0.00014 & 0.99569 & 0.00015 & 1.00417 & 0.00015 \\
\hline 11 & B-SS & 0.99758 & 0.00014 & 0.99587 & 0.00014 & 1.00409 & 0.00015 \\
\hline 12 & Boral $^{\circledR}$ & 0.99948 & 0.00014 & 0.99844 & 0.00015 & 1.00584 & 0.00015 \\
\hline 13 & Boral $^{\circledR}$ & 0.99511 & 0.00015 & 0.99424 & 0.00015 & 1.00143 & 0.00015 \\
\hline 14 & $\mathrm{Cd}$ & 1.00085 & 0.00014 & 1.00131 & 0.00014 & 1.01022 & 0.00015 \\
\hline 15 & $\mathrm{Cd}$ & 0.99485 & 0.00014 & 0.99522 & 0.00014 & 1.00359 & 0.00015 \\
\hline 16 & $\mathrm{Cd}$ & 0.99553 & 0.00014 & 0.99472 & 0.00015 & 1.00 & 0.00015 \\
\hline 17 & $\mathrm{Cd}$ & 0.99381 & 0.00014 & 0.99260 & 0.00014 & 1.00049 & 0.00015 \\
\hline 18 & $\mathrm{Cd}$ & 0.99294 & 0.00014 & 0.99200 & 0.00015 & 0.99968 & 0.00015 \\
\hline 19 & $\mathrm{Cd}$ & 0.99270 & 0.00014 & 0.99210 & 0.00014 & 0.99856 & 0.00015 \\
\hline 20 & $\mathrm{Cd}$ & 0.99237 & 0.00014 & 0.99122 & 0.00015 & 0.99797 & 0.00015 \\
\hline 21 & $\mathrm{Cd}$ & 0.99630 & 0.00014 & 0.99577 & 0.00014 & 1.00399 & 0.00015 \\
\hline 22 & none & 0.99995 & 0.00014 & 0.99762 & 0.00014 & 1.00820 & 0.00015 \\
\hline 23 & none & 1.00029 & 0.00014 & 0.99827 & 0.00015 & 1.00792 & 0.00015 \\
\hline 24 & none & 0.99946 & 0.00015 & 0.99735 & 0.00014 & 1.00580 & 0.00015 \\
\hline 25 & none & 0.99941 & 0.00014 & 0.99818 & 0.00015 & 1.00528 & 0.00015 \\
\hline 26 & none & 0.99900 & 0.00015 & 0.99800 & 0.00015 & 1.00532 & 0.00015 \\
\hline 27 & none & 0.99893 & 0.00015 & 0.99842 & 0.00014 & 1.00427 & 0.00015 \\
\hline 28 & none & 0.99879 & 0.00015 & 0.99890 & 0.00016 & 1.00428 & 0.00015 \\
\hline 29 & none & 0.99883 & 0.00014 & 0.99652 & 0.00014 & 1.00433 & 0.00015 \\
\hline 30 & none & 0.99930 & 0.00015 & 0.99691 & 0.00014 & 1.00406 & 0.00015 \\
\hline 31 & none & 0.99896 & 0.00015 & 0.99656 & 0.00014 & 1.00375 & 0.00015 \\
\hline 32 & none & 0.99918 & 0.00014 & 0.99688 & 0.00014 & 1.00400 & 0.00015 \\
\hline 33 & none & 0.99901 & 0.00016 & 0.99686 & 0.00015 & 1.00395 & 0.00015 \\
\hline
\end{tabular}




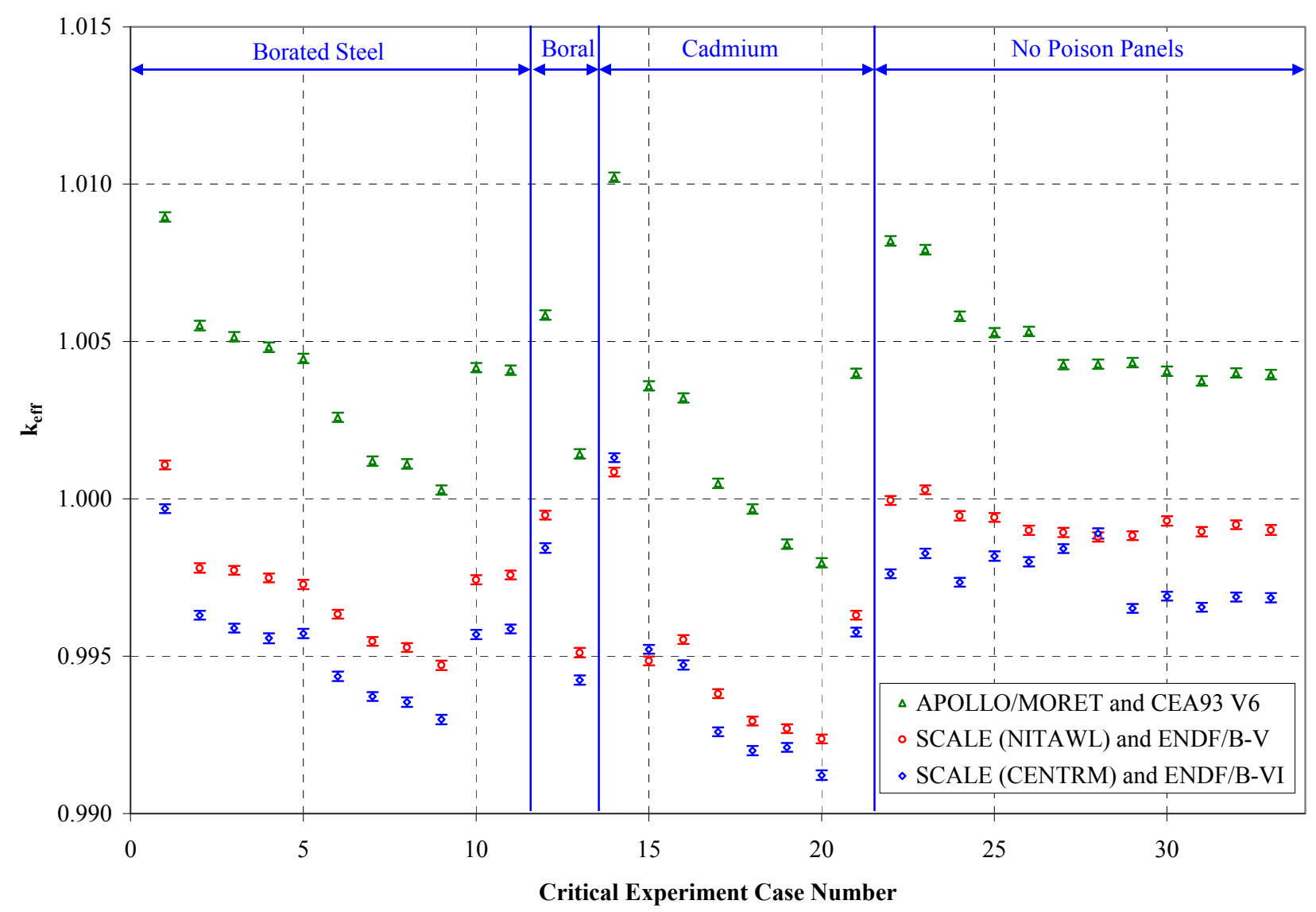

Figure 4.12 Phase 4 experiments with steel reflector 
Table 4.6 Calculated $\boldsymbol{k}_{\text {eff }}$ values for Phase 4 experiments with lead reflector

\begin{tabular}{|c|c|c|c|c|c|c|c|}
\hline \multirow[t]{2}{*}{ Case } & \multirow[t]{2}{*}{$\begin{array}{l}\text { Poison } \\
\text { Plate }\end{array}$} & \multicolumn{2}{|c|}{$\begin{array}{l}\text { SCALE } 5.1 \\
\text { (NITAWL) } \\
\text { ENDF/B-V }\end{array}$} & \multicolumn{2}{|c|}{$\begin{array}{l}\text { SCALE 5.1 } \\
(\text { CENTRM) } \\
\text { ENDF/B-VI }\end{array}$} & \multicolumn{2}{|c|}{$\begin{array}{c}\text { APOLLO2.5.4- } \\
\text { MORET4.B.3 } \\
\text { CEA93 V6 (Ref.4) }\end{array}$} \\
\hline & & $k_{\text {eff }}$ & $\sigma$ & $k_{\text {eff }}$ & $\sigma$ & $k_{\text {eff }}$ & $\boldsymbol{\sigma}$ \\
\hline 1 & B-SS & 1.00137 & 0.00014 & 0.99960 & 0.00015 & 1.00730 & 0.00015 \\
\hline 2 & B-SS & 0.99862 & 0.00014 & 0.99644 & 0.00014 & 1.00467 & 0.00015 \\
\hline 3 & B-SS & 0.99829 & 0.00015 & 0.99606 & 0.00014 & 1.00420 & 0.00015 \\
\hline 4 & B-SS & 0.99846 & 0.00014 & 0.99660 & 0.00014 & 1.00410 & 0.00015 \\
\hline 5 & B-SS & 0.99853 & 0.00014 & 0.99644 & 0.00015 & 1.00365 & 0.00015 \\
\hline 6 & B-SS & 0.99858 & 0.00014 & 0.99650 & 0.00015 & 1.00358 & 0.00015 \\
\hline 7 & B-SS & 0.99911 & 0.00014 & 0.99684 & 0.00015 & 1.00353 & 0.00015 \\
\hline 8 & B-SS & 0.99789 & 0.00015 & 0.99520 & 0.00014 & 1.00224 & 0.00015 \\
\hline 9 & B-SS & 0.99685 & 0.00014 & 0.99493 & 0.00015 & 1.00203 & 0.00015 \\
\hline 10 & B-SS & 0.99660 & 0.00013 & 0.99449 & 0.00015 & 1.00112 & 0.00015 \\
\hline 11 & B-SS & 0.99597 & 0.00014 & 0.99407 & 0.00015 & 1.00064 & 0.00015 \\
\hline 12 & Boral $^{\circledR}$ & 1.00063 & 0.00015 & 0.99858 & 0.00014 & 1.00507 & 0.00015 \\
\hline 13 & Boral $^{\circledR}$ & 1.00061 & 0.00014 & 0.99918 & 0.00015 & 1.00556 & 0.00015 \\
\hline 14 & Boral $^{\circledR}$ & 0.99935 & 0.00015 & 0.99789 & 0.00015 & 1.00432 & 0.00015 \\
\hline 15 & Boral $^{\circledR}$ & 0.99625 & 0.00014 & 0.99482 & 0.00014 & 1.00082 & 0.00015 \\
\hline 16 & Boral $^{\circledR}$ & 0.99633 & 0.00016 & 0.99461 & 0.00014 & 1.00098 & 0.00015 \\
\hline 17 & $\mathrm{Cd}$ & 1.00300 & 0.00014 & 1.00277 & 0.00014 & 1.00976 & 0.00015 \\
\hline 18 & $\mathrm{Cd}$ & 0.99705 & 0.00015 & 0.99612 & 0.00014 & 1.00297 & 0.00015 \\
\hline 19 & $\mathrm{Cd}$ & 0.99757 & 0.00015 & 0.99636 & 0.00014 & 1.00289 & 0.00015 \\
\hline 20 & $\mathrm{Cd}$ & 0.99830 & 0.00014 & 0.99699 & 0.00014 & 1.00371 & 0.00015 \\
\hline 21 & $\mathrm{Cd}$ & 0.99584 & 0.00015 & 0.99485 & 0.00015 & 0.99978 & 0.00015 \\
\hline 22 & $\mathrm{Cd}$ & 0.99522 & 0.00015 & 0.99413 & 0.00015 & 0.99952 & 0.00015 \\
\hline 23 & $\mathrm{Cd}$ & 0.99450 & 0.00015 & 0.99356 & 0.00015 & 1.00307 & 0.00015 \\
\hline 24 & $\mathrm{Cd}$ & 0.99421 & 0.00015 & 0.99304 & 0.00014 & 1.00347 & 0.00015 \\
\hline 25 & $\mathrm{Cd}$ & 0.99776 & 0.00015 & 0.99677 & 0.00014 & 1.00191 & 0.00015 \\
\hline 26 & $\mathrm{Cd}$ & 0.99865 & 0.00014 & 0.99713 & 0.00015 & 1.00011 & 0.00015 \\
\hline 27 & none & 0.99938 & 0.00016 & 0.99694 & 0.00015 & 1.00581 & 0.00015 \\
\hline 28 & none & 1.00028 & 0.00014 & 0.99719 & 0.00015 & 1.00602 & 0.00015 \\
\hline 29 & none & 0.99984 & 0.00014 & 0.99708 & 0.00013 & 1.00412 & 0.00015 \\
\hline 30 & none & 1.00018 & 0.00014 & 0.99719 & 0.00014 & 1.00320 & 0.00015 \\
\hline 31 & none & 1.00009 & 0.00014 & 0.99741 & 0.00014 & 1.00284 & 0.00015 \\
\hline 32 & none & 1.00014 & 0.00015 & 0.99748 & 0.00014 & 1.00313 & 0.00015 \\
\hline 33 & none & 1.00049 & 0.00014 & 0.99772 & 0.00014 & 1.00358 & 0.00015 \\
\hline 34 & none & 1.00077 & 0.00015 & 0.99825 & 0.00015 & 1.00356 & 0.00015 \\
\hline 35 & none & 1.00006 & 0.00014 & 0.99827 & 0.00014 & 1.00445 & 0.00015 \\
\hline 36 & none & 1.00004 & 0.00014 & 0.99921 & 0.00014 & 1.00505 & 0.00015 \\
\hline 37 & none & 0.99994 & 0.00015 & 0.99982 & 0.00015 & 1.00450 & 0.00015 \\
\hline 38 & none & 0.99972 & 0.00014 & 1.00026 & 0.00014 & 1.00399 & 0.00015 \\
\hline
\end{tabular}




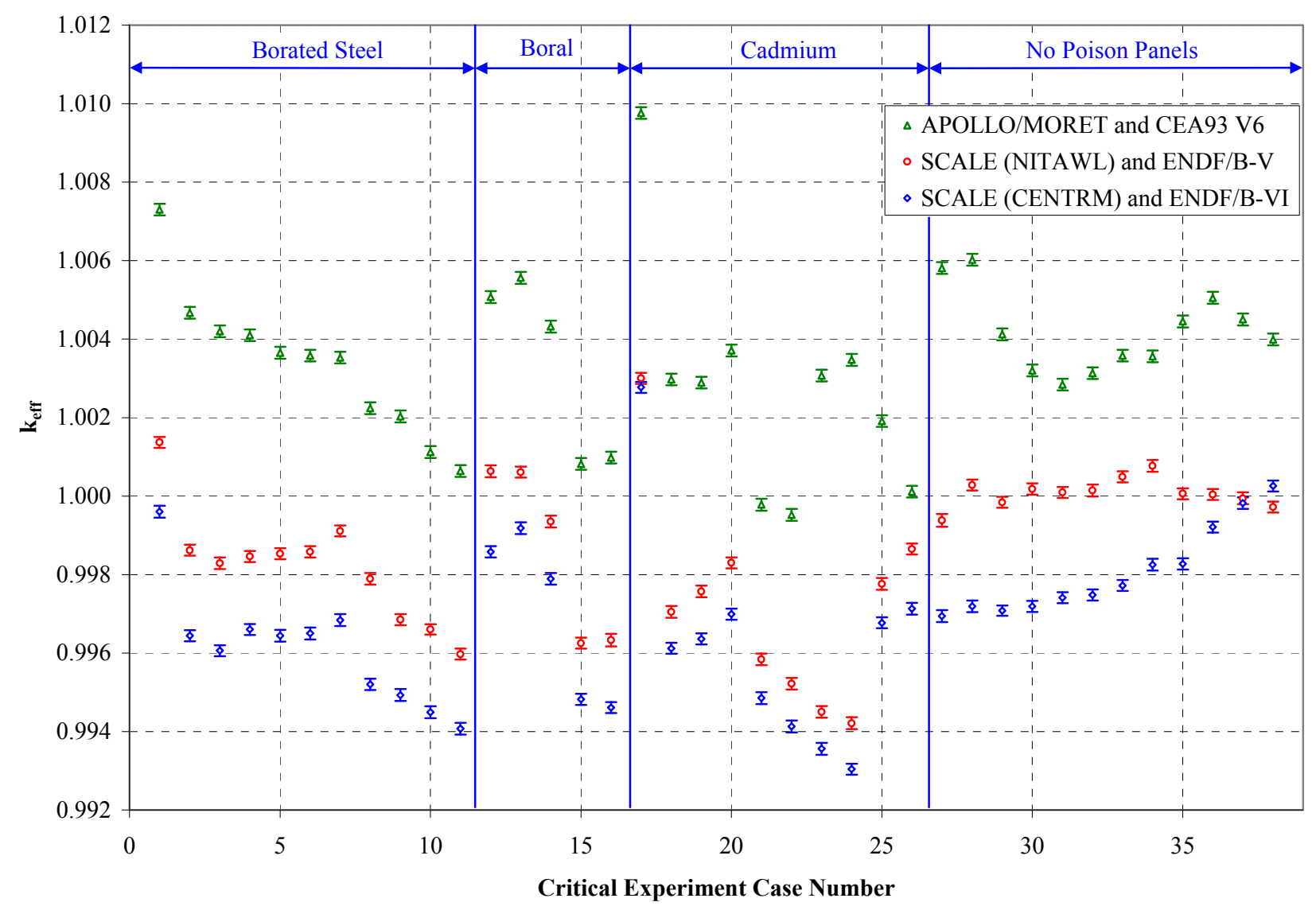

Figure 4.13 Phase 4 experiments with lead reflector 


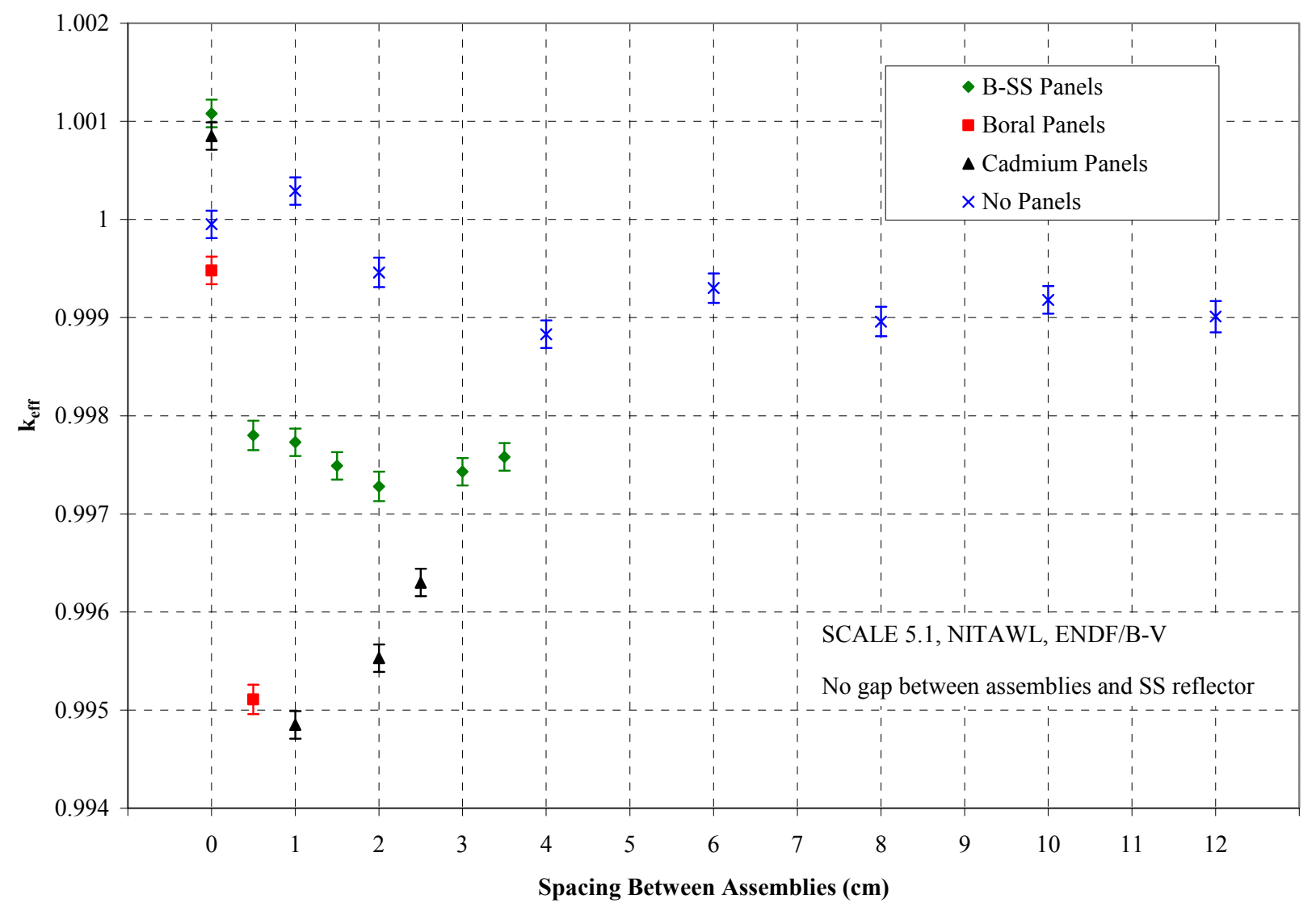

Figure 4.14 Variation of calculated $k_{\text {eff }}$ with changes in the size of the gap between assemblies in the steel reflected cases 


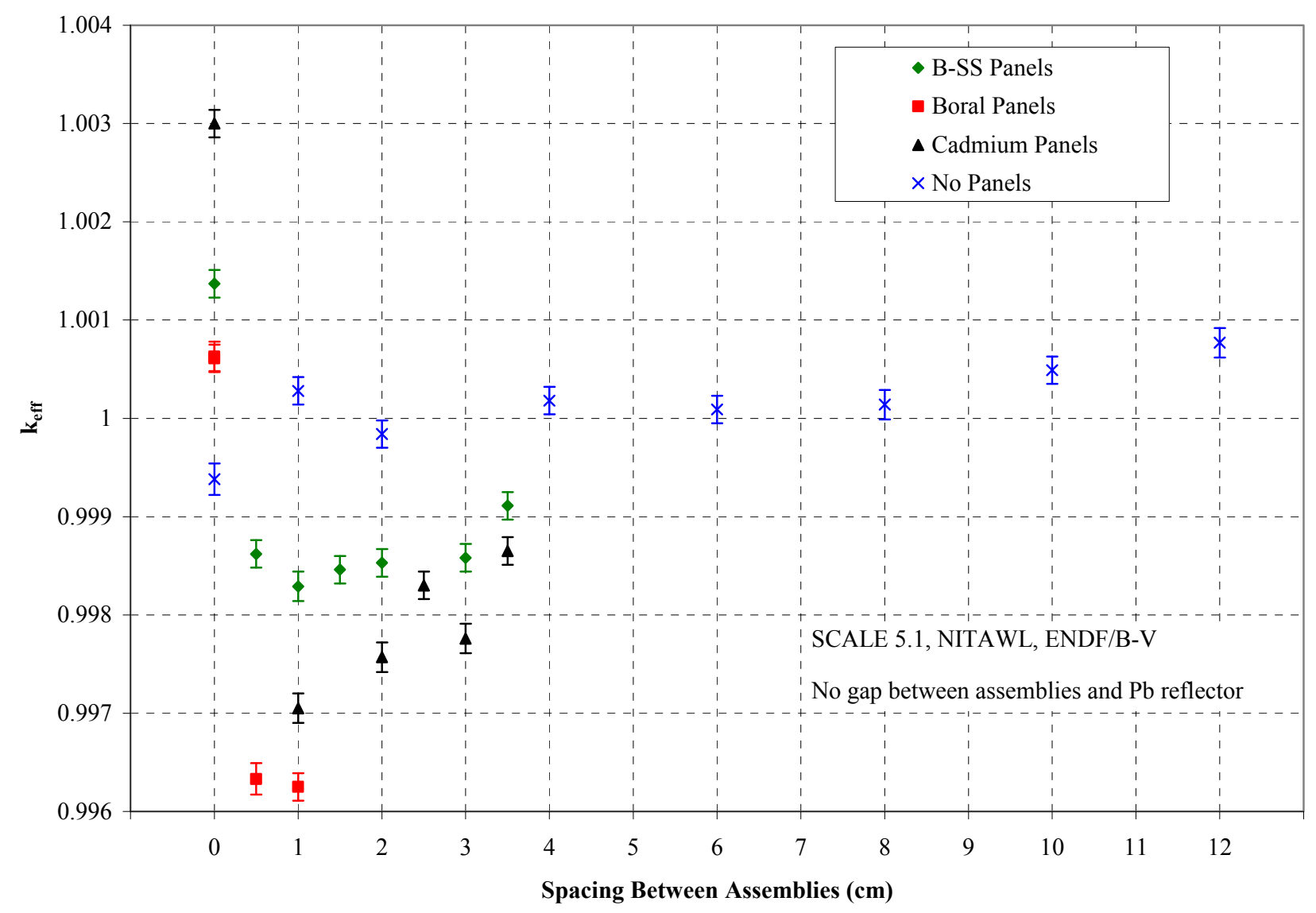

Figure 4.15 Variation of calculated $\boldsymbol{k}_{\text {eff }}$ with changes in the size of the gap between assemblies in the lead reflected cases 


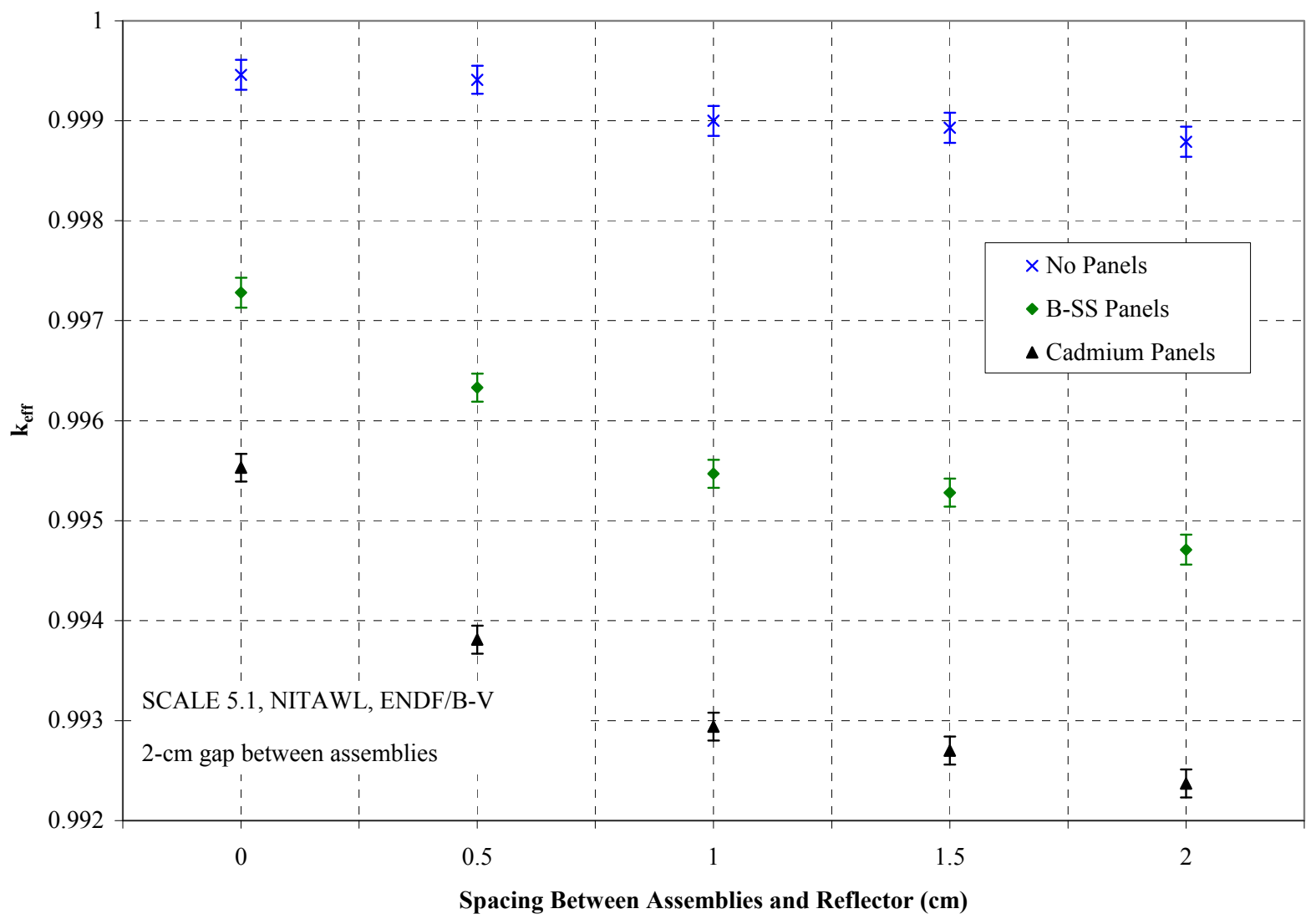

Figure 4.16 Variation of calculated $\boldsymbol{k}_{\text {eff }}$ with changes in the gap size between the assemblies and the steel reflector 


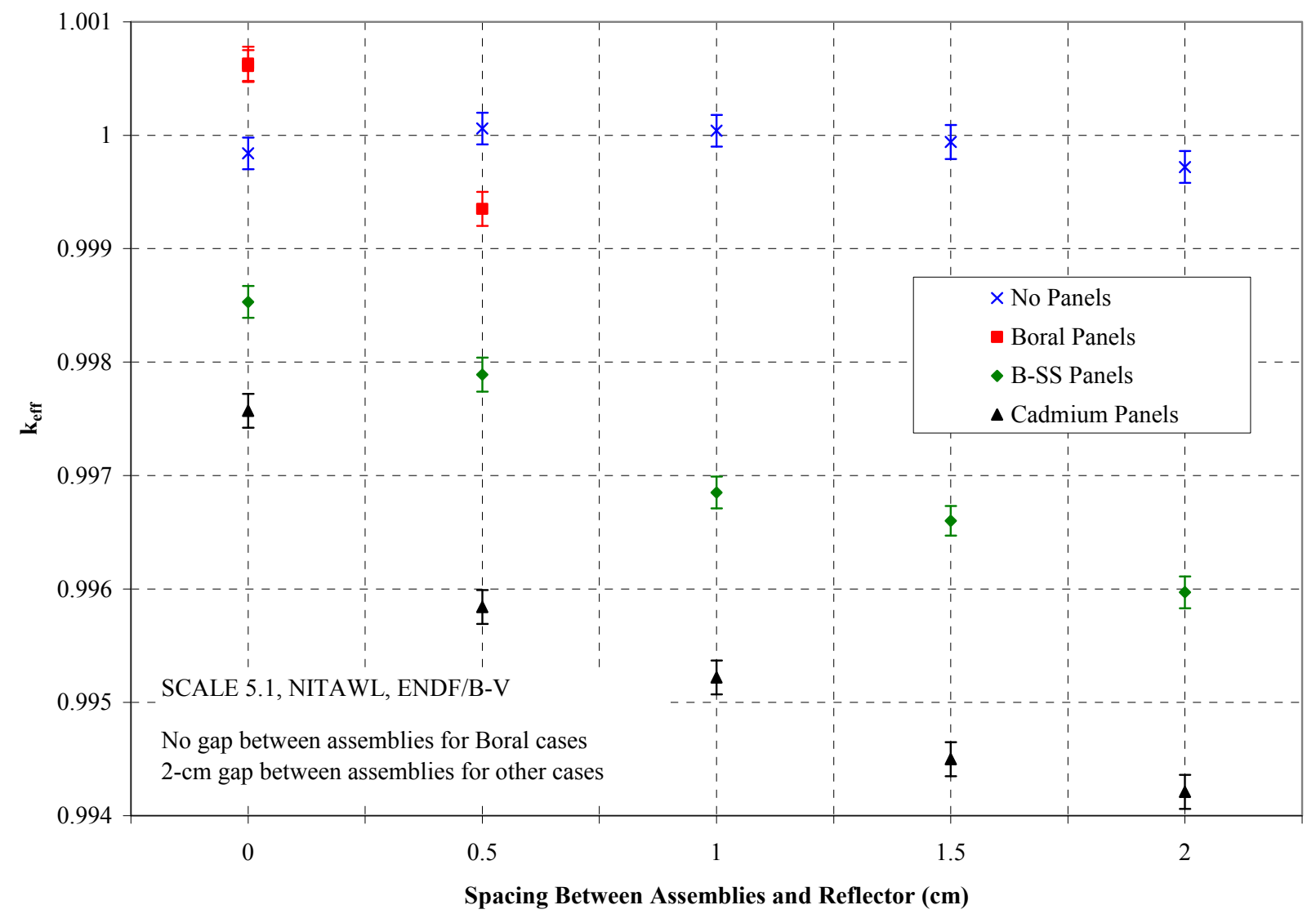

Figure 4.17 Variation of calculated $\boldsymbol{k}_{\text {eff }}$ with changes in the gap size between the assemblies and the lead reflector 



\section{BURNUP CREDIT CASK MODEL}

A generic cask model with a 32-PWR assembly capacity, referred to as the GBC-32 and described in NUREG/CR-6747 (Ref. 9), was previously developed to serve as a computational benchmark. The features of the GBC-32 model include 32 cells with $365.76-\mathrm{cm}$-tall and 19.05 -cm-wide Boral ${ }^{\circledR}$ $\left(0.0225 \mathrm{~g}{ }^{10} \mathrm{~B} / \mathrm{cm}^{2}\right)$ panels between and on the external faces of each cell. The cells have inner dimensions of 22 by $22 \mathrm{~cm}$ and are spaced on $23.76-\mathrm{cm}$ centers. The cell walls are constructed of stainless steel. The cells sit $15 \mathrm{~cm}$ above the bottom of a stainless steel cask having an inner radius of $87.5 \mathrm{~cm}$ and internal height of $410.76 \mathrm{~cm}$. The radial thickness of the side walls is $20 \mathrm{~cm}$, and the cask bottom and lid are $30 \mathrm{~cm}$ thick. Figure 5.1 shows a cutaway view of the KENO V.a cask model.

For purposes of the analyses documented in this report, the cask was modeled as loaded with Westinghouse $17 \times 17$ Optimized Fuel Assemblies (W17×17OFA). The dimensions for the W17×17OFA were taken from Table 3 of Ref. 9 . The fuel pin pitch is $1.2598 \mathrm{~cm}$. The interior of the cask was modeled as filled with water.

The fuel in the cask was modeled using a set of initial enrichment and burnup values taken from a typical burnup credit limit curve, shown in Table 5.1. The STARBUCS ${ }^{10}$ sequence in SCALE 5.1 was used to generate 18 axial location-dependent burned fuel compositions. The normalized burnup profiles provided in Table C10.6.8 of Ref. 10 were used. The fuel burnup calculations model the depletion of the ${ }^{235} \mathrm{U}$ and

${ }^{238} \mathrm{U}$ and the in-growth of actinide and fission product nuclides. Table 5.1 also gives the uranium and plutonium isotopic composition as calculated by STARBUCS for burnup values ranging from 0 to $70 \mathrm{GWd} / \mathrm{MTU}$. The calculated fuel composition for $40 \mathrm{GWd} / \mathrm{MTU}$ is reasonably similar to the HTC fuel rod composition shown in Table 5.1. From the depletion calculations, fuel compositions for the following nuclides were retained for the criticality and sensitivity calculations: ${ }^{234} \mathrm{U},{ }^{235} \mathrm{U},{ }^{236} \mathrm{U},{ }^{238} \mathrm{U}$, ${ }^{237} \mathrm{~Np},{ }^{238} \mathrm{Pu},{ }^{239} \mathrm{Pu},{ }^{240} \mathrm{Pu},{ }^{241} \mathrm{Pu},{ }^{242} \mathrm{Pu},{ }^{241} \mathrm{Am},{ }^{243} \mathrm{Am},{ }^{95} \mathrm{Mo},{ }^{99} \mathrm{Tc},{ }^{101} \mathrm{Ru},{ }^{103} \mathrm{Rh},{ }^{109} \mathrm{Ag},{ }^{133} \mathrm{Cs},{ }^{147} \mathrm{Sm},{ }^{149} \mathrm{Sm}$, ${ }^{150} \mathrm{Sm},{ }^{151} \mathrm{Sm},{ }^{152} \mathrm{Sm},{ }^{143} \mathrm{Nd},{ }^{145} \mathrm{Nd},{ }^{151} \mathrm{Eu},{ }^{153} \mathrm{Eu}$, and ${ }^{155} \mathrm{Gd}$.

The GBC-32 is used in this report as the safety basis case or "application" and is used for comparison with the critical experiments to determine which critical experiments are similar enough to the GBC-32 to be used in bias and bias uncertainty determination analyses. The next-to-last row of Table 5.1 is the measured data for spent fuel sample SF95-4 from the Takahama Unit 3 nuclear power plant (Reference 11). The last row is the composition of the HTC experiment fuel (Reference 12). These rows are provided in this table for comparison with the other data in this table. Note that the last two rows are fairly similar to the burnup credit curve point at $40 \mathrm{GWd} / \mathrm{MTU}$.

The validation study for a real burnup credit criticality safety analysis must validate points along the burnup credit limit curve. The uranium/plutonium compositions for these points may vary significantly from typical or average SNF compositions, depending somewhat on the amount of burnup credit required and on adoption of conservative composition models for use in the burnup credit analysis. 
Table 5.1 Uranium and plutonium compositions for burned PWR fuel

\begin{tabular}{|c|c|c|c|c|c|c|}
\hline \multirow{2}{*}{$\begin{array}{c}\text { Assembly } \\
\text { burnup } \\
\text { (GWd/MTU) }\end{array}$} & \multicolumn{2}{|c|}{$\begin{array}{l}\text { Uranium composition } \\
\left(\mathbf{w t} \%{ }^{235} \mathrm{U}\right)\end{array}$} & \multicolumn{4}{|c|}{$\begin{array}{l}\text { Plutonium composition } \\
\text { (assembly average) }\end{array}$} \\
\hline & Initial & $\begin{array}{c}\text { Average } \\
\text { final }\end{array}$ & $\begin{array}{c}\mathrm{Pu} /(\mathbf{P u}+\mathrm{U}) \\
(\mathbf{w t} \%)\end{array}$ & $\begin{array}{c}{ }^{239} \mathrm{Pu} / \mathrm{Pu} \\
(\mathrm{wt} \%)\end{array}$ & $\begin{array}{c}{ }^{240} \mathrm{Pu} / \mathrm{Pu} \\
(\mathrm{wt} \%)\end{array}$ & $\begin{array}{c}{ }^{241} \mathrm{Pu} / \mathrm{Pu} \\
(w \mathrm{\%} \%)\end{array}$ \\
\hline 0 & 1.950 & 1.950 & 0.00 & $\mathrm{~N} / \mathrm{A}$ & $\mathrm{N} / \mathrm{A}$ & $\mathrm{N} / \mathrm{A}$ \\
\hline 10 & 1.997 & 1.227 & 0.58 & 77.4 & 15.7 & 5.7 \\
\hline 20 & 2.556 & 1.145 & 0.86 & 67.6 & 20.1 & 8.9 \\
\hline 30 & 3.203 & 1.140 & 1.05 & 62.1 & 21.9 & 10.5 \\
\hline 40 & 3.778 & 1.094 & 1.22 & 58.3 & 22.7 & 11.4 \\
\hline 50 & 4.343 & 1.046 & 1.36 & 55.4 & 23.1 & 11.9 \\
\hline 60 & 4.882 & 0.986 & 1.50 & 53.0 & 23.3 & 12.2 \\
\hline 70 & 5.438 & 0.943 & 1.62 & 51.2 & 23.3 & 12.3 \\
\hline $36.7(\mathrm{SNF})^{11}$ & 4.11 & 1.29 & 1.07 & 58.2 & 21.4 & 14.2 \\
\hline $37.5(\mathrm{HTC})^{12}$ & 4.5 & 1.57 & 1.1 & 59.2 & 24.3 & 10.1 \\
\hline
\end{tabular}

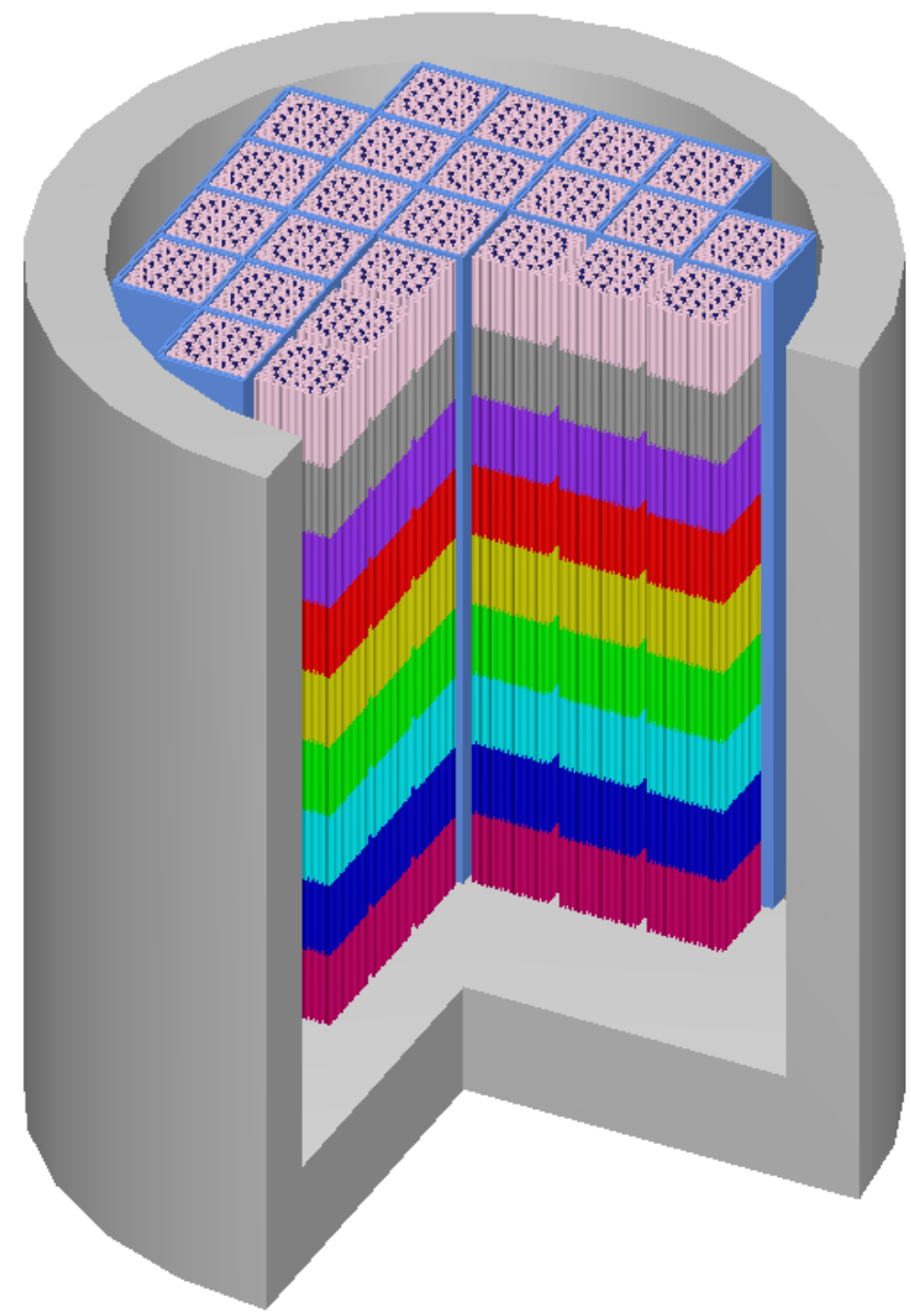

Figure 5.1 Cutaway view of the KENO V.a model for the GBC-32 cask showing the cask bottom half with a quarter of the model removed 


\section{SENSITIVITY/UNCERTAINTY ANALYSIS}

Sensitivity/Uncertainty analysis, using the TSUNAMI-3D sequence and the TSUNAMI-IP module developed at ORNL and distributed as part of the SCALE 5.1 package, was used to help quantify the applicability of these experiments for the validation of burnup credit applications such as the GBC-32 cask model. The SCALE ENDF/B-V and ENDF/B-VI 238-group cross-section libraries were used for these calculations.

TSUNAMI-3D is a Monte Carlo-based eigenvalue sensitivity analysis sequence that was released with SCALE 5.1. This software tool permits energy-, mixture-, nuclide- and region-dependent examination of the sensitivity of the system $k_{\text {eff }}$ to variations in nuclear data of modeled materials. TSUNAMI-3D uses first-order linear-perturbation theory to produce sensitivity coefficients. ${ }^{13}$ The TSUNAMI-3D sequence uses KENO V.a to perform forward and adjoint calculations. Then the SAMS program uses the forward and adjoint solutions in a standard linear perturbation theory method to produce neutron energydependent sensitivity profiles. The profiles for each modeled system are saved into a sensitivity data file (SDF). To increase confidence that the sensitivity profiles were accurate, some direct perturbation calculations were performed on selected important nuclides. As implemented in the TSUNAMI tools, sensitivity is the fractional change in the $k_{\text {eff }}$ value resulting from a fractional change in the nuclear data parameter of interest. For example, if the capture sensitivity for ${ }^{10} \mathrm{~B}$ in the model is -0.1 , then a $1 \%$ increase in the capture cross sections would result in a $0.1 \%$ reduction in the system $k_{\text {eff }}$ value.

The relative importance of an actinide isotope in a burnup credit analysis may be represented as the absolute value of its sensitivity coefficient as calculated for a particular application. Using the burnup and initial enrichment combinations shown in Table 5.1, the sensitivity coefficients for several actinide isotopes were calculated as a function of burnup in the GBC-32 cask. These values are shown as a

function of burnup in Figure 6.1. While the contributions from the three most important actinides $\left({ }^{235} \mathrm{U}\right.$, ${ }^{239} \mathrm{Pu}$, and ${ }^{238} \mathrm{U}$ ) stay relatively constant, those from other actinides change significantly with increased burnup. 


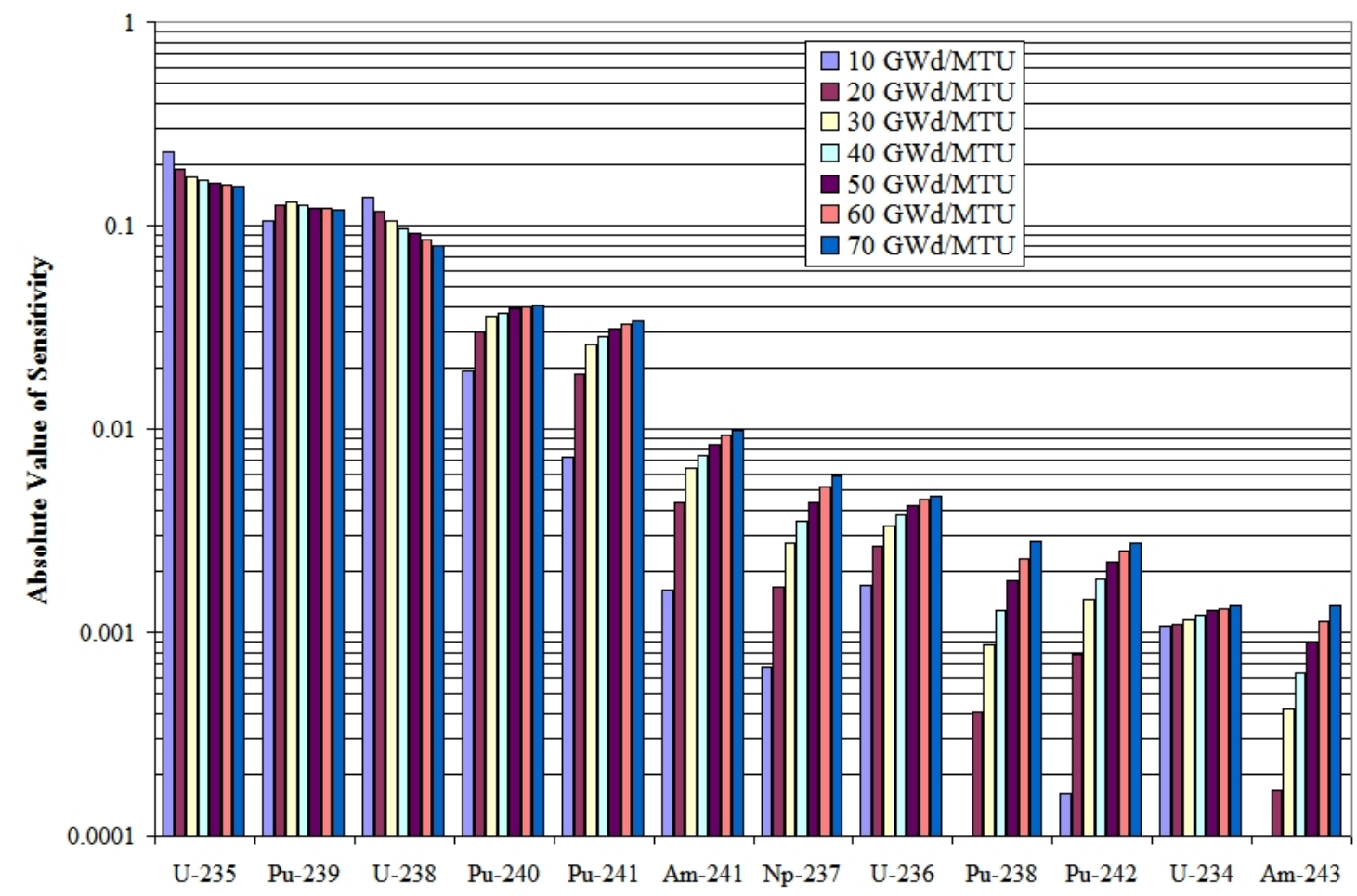

Figure 6.1 Relative actinide isotope importance in the GBC-32 cask

TSUNAMI-IP is used to compare the sensitivity data for two systems. It generates a variety of total and partial relational parameters that quantify the similarities between two systems. The similarity work presented in this report utilizes the $c_{\mathrm{k}}$ parameter. The $c_{\mathrm{k}}$ parameter is a single-valued parameter used to assess similarity of nuclear data uncertainty-weighted sensitivity profiles for all nuclide-reactions between a design system and a critical experiment. The value of $c_{k}$ varies between zero, for two completely dissimilar systems, and 1.0, for two identical systems. The premise behind the $c_{\mathrm{k}}$ parameter is that calculation biases are due primarily to errors in cross-section data with larger uncertainties. Systems that demonstrate similarly high sensitivities to highly uncertain cross-section data will have similar computational biases. The current guidance ${ }^{13}$ based on experience at ORNL is that a critical configuration is applicable to an evaluation case if the $c_{k}$ value is $\geq 0.9$; a critical configuration is considered marginally applicable if $c_{k}$ is $\geq 0.8$ and $<0.9$; and a critical configuration is not applicable if $c_{k}$ $<0.8$.

When compared to the GBC-32 cask loaded with fuel burned to at least $40 \mathrm{GWd} / \mathrm{MTU}, 152$ of the 156 HTC experiments had a $c_{k}$ value of $\geq 0.9$. The remaining four configurations had $c_{k} \geq 0.8$ but less than 0.9. This is shown in Figure 6.2.

From examination of Figure 6.2, there appear to be some systematic trends in $c_{k}$ values. These trends are related primarily to the level of neutron moderation in and around the fuel pins. The fuel assembly in the GBC-32 model has a pin pitch of $1.2598 \mathrm{~cm}$. As shown in Figure 6.3, the HTC experiment configurations with pin pitch closest to this value yielded the highest $c_{k}$ values. The largest spread in the $c_{k}$ value results is evident in the Phase 1 results, for which $c_{k}$ results vary from 0.89 to nearly 0.97 . In the Phase 1 results shown in Figure 6.2, moving from left to right there are three configurations at each of the following pin-pitch values: $2.3,1.9,1.7,1.5,1.3$, and $1.7 \mathrm{~cm}$. The changing $\mathrm{c}_{\mathrm{k}}$ values for each set clearly reflect the variation of the assembly pin pitch, with the maximum values produced by the configurations with pin pitch closest to the fuel assembly modeled in the GBC-32 model. 


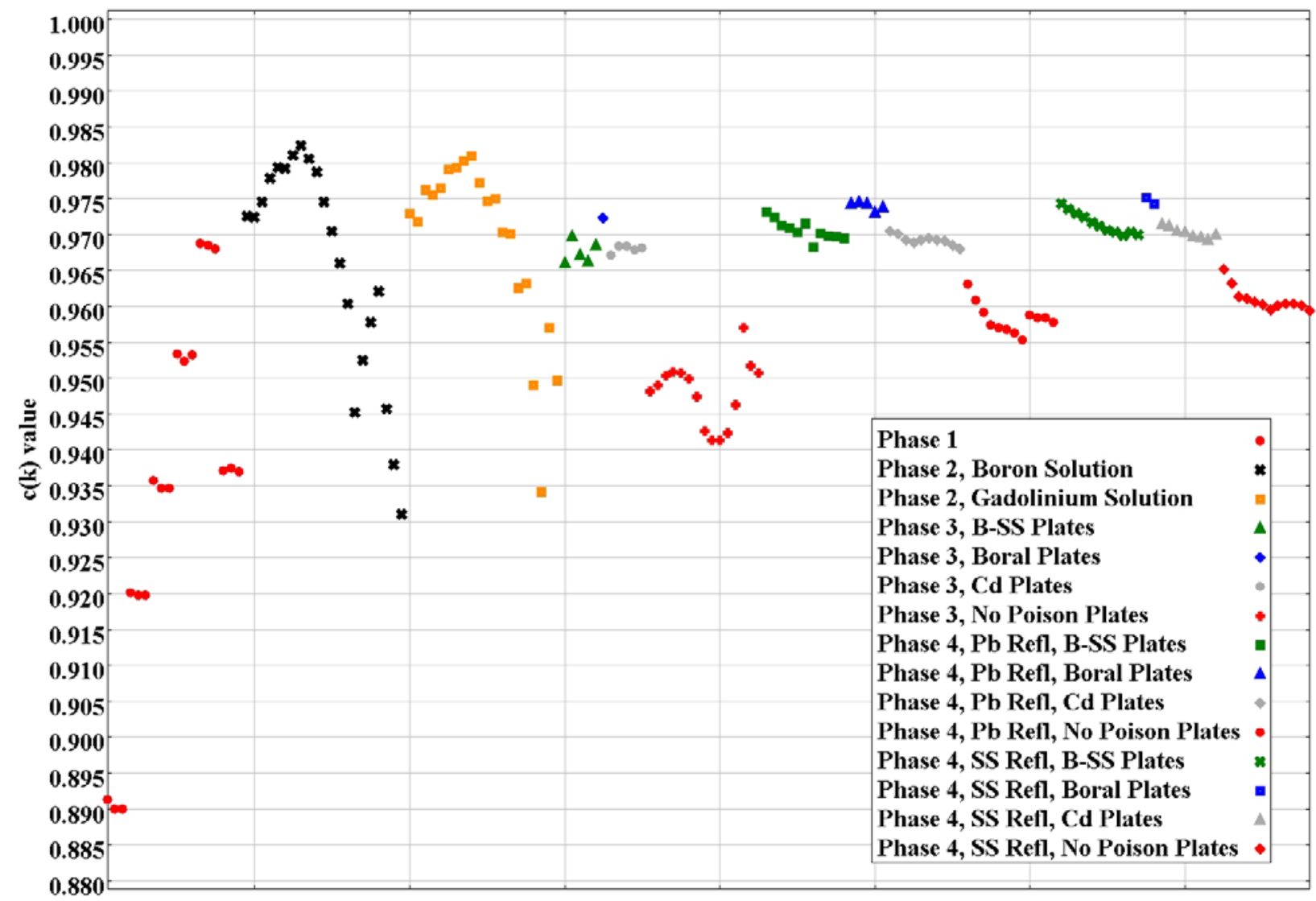

Figure 6.2 Comparison of HTC experiments to GBC-32 cask model with 40 GWd/MTU fuel

The $c_{k}$ value trends in the Phase 2 boron and gadolinium solution configurations reflect the variation in pin pitch. They also show the effect of varying the soluble poison concentrations. Addition of the soluble poisons in the Phase 2, poison panels in Phases 3 and 4, and the lead and steel reflectors in Phase 4 all harden the neutron energy spectrum in the same way that reducing the pin pitch hardens the spectrum. Note that the GBC-32 cask includes Boral ${ }^{\circledR}$ and steel plates around each assembly. These plates harden the spectrum in the GBC-32 relative to what would be seen without the plates. The trends shown in Figure 6.2 are in general showing relatively minor variations of the $c_{k}$ values. If the HTC rods had contained only uranium or only plutonium, other work [Ref. 5] has shown that the $c_{k}$ values would have all been around 0.5 to 0.6 . 


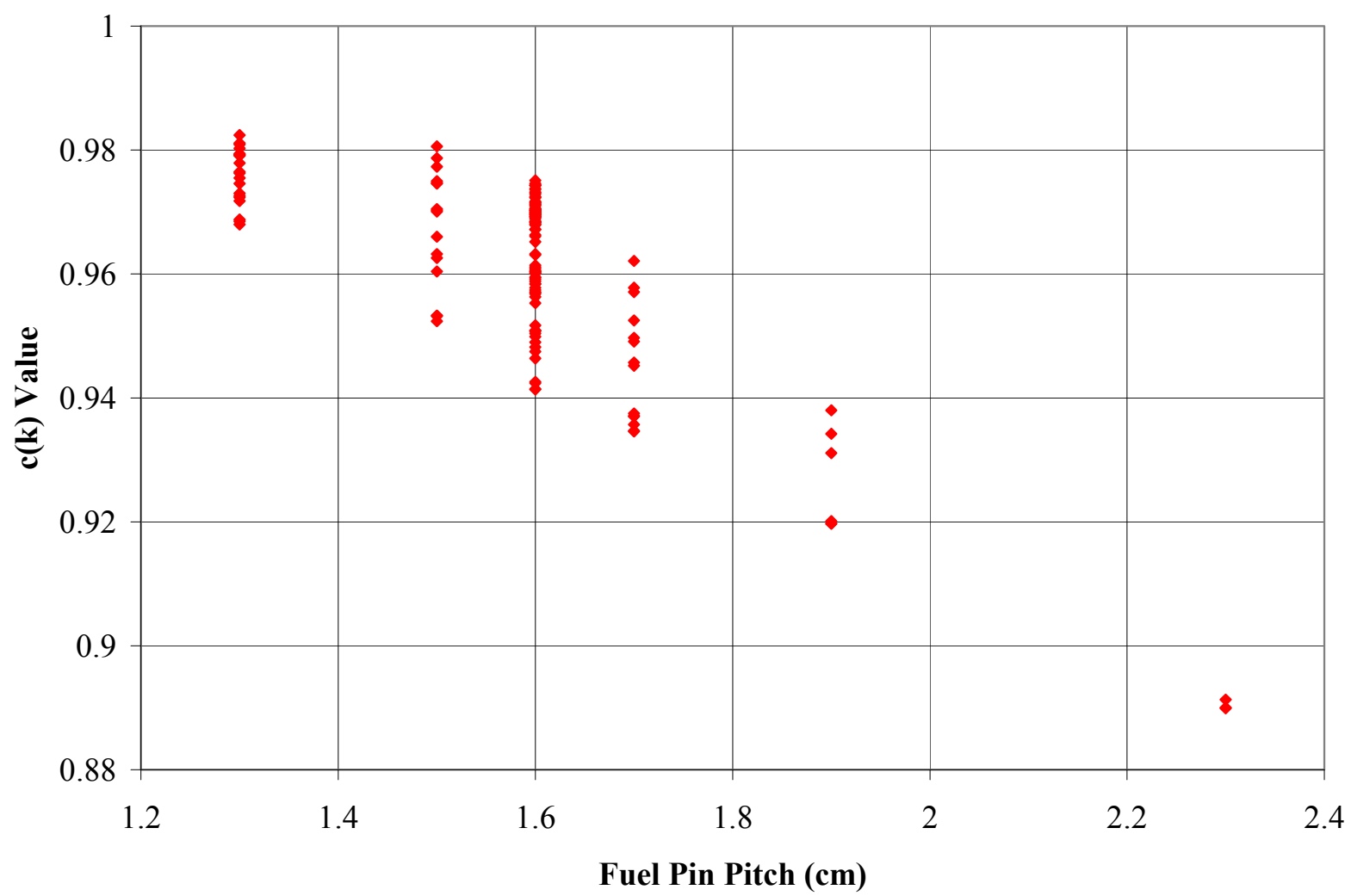

Figure 6.3 Variation of $c_{k}$ with HTC experiment fuel pin pitch

Figure 6.4 shows the same 156 HTC experiments compared to the GBC-32 cask model with assembly average fuel burnups of 10, 20, 40 and $70 \mathrm{GWd} / \mathrm{MTU}$. The $\mathrm{c}_{\mathrm{k}}$ values show that the HTC experiments are at least marginally applicable even for fuel burned to only $10 \mathrm{GWd} / \mathrm{MTU}$. The $\mathrm{c}_{\mathrm{k}}$ values increase for fuel burned to $20 \mathrm{GWd} / \mathrm{MTU}$ and are highest for the fuel burned to $40 \mathrm{GWd} / \mathrm{MTU}$. For higher burnups, the values of $\mathrm{c}_{\mathrm{k}}$ begin to decrease slowly and are not significantly lower even for fuel burned to 70

$\mathrm{GWd} / \mathrm{MTU}$. At a burnup of $70 \mathrm{GWd} / \mathrm{MTU}$, the $\mathrm{c}_{\mathrm{k}}$ values are similar to or somewhat higher than those for $20 \mathrm{GWd} / \mathrm{MTU}$. 


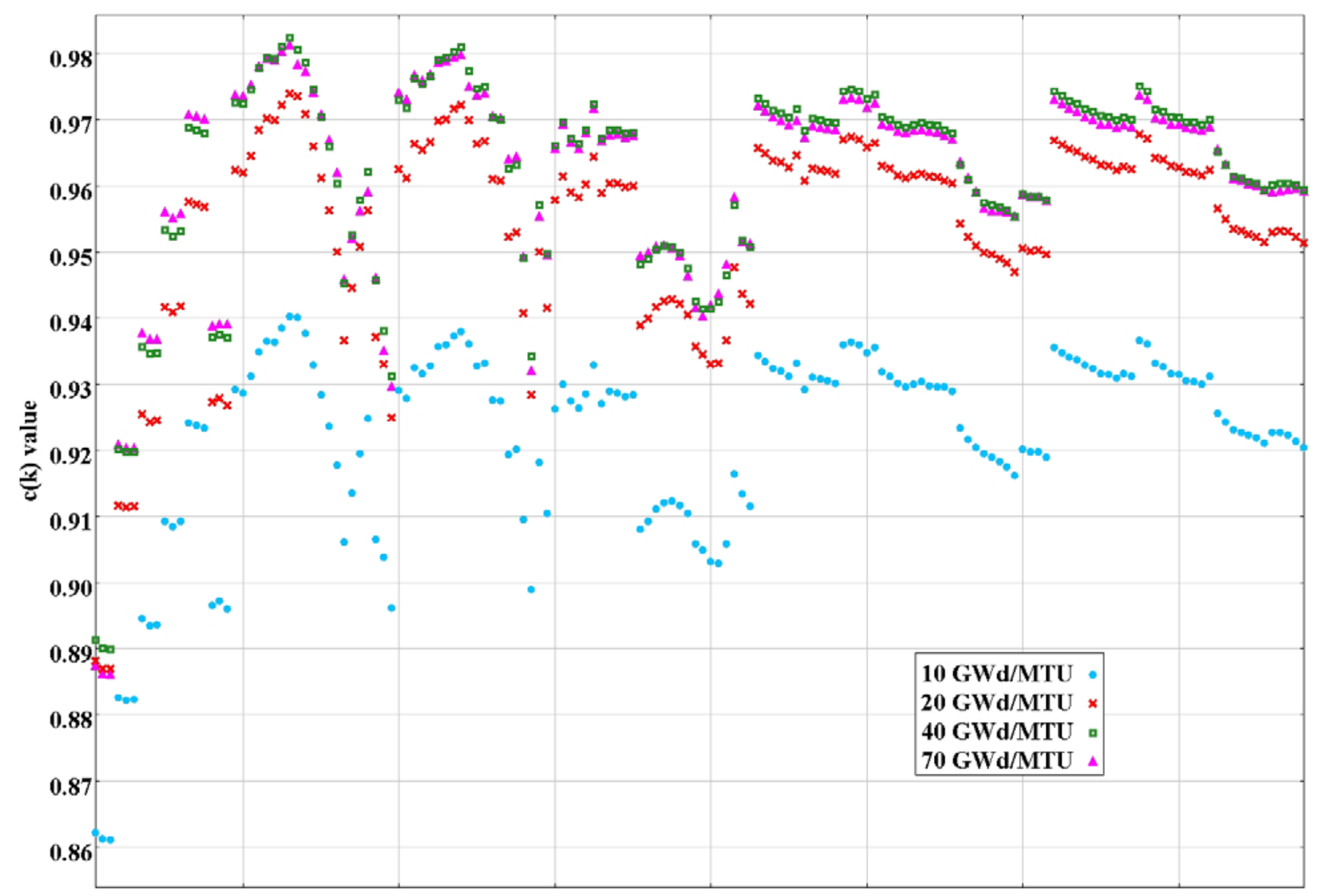

Figure 6.4 Comparison of HTC experiments to GBC-32 cask model with fuel burned to 10, 20, 40, and $70 \mathrm{GWd} / \mathrm{MTU}$ 
Reference 5 provides a sensitivity/uncertainty comparison of the GBC-32 cask model with a larger set of benchmark experiments. The GBC-32 cask was loaded as it is described above, with fuel burned to $40 \mathrm{GWd} / \mathrm{MTU}$. The benchmarks included experiments that have typically been used in validations for burnup credit applications and MOX fuel fabrication applications. The resulting $c_{k}$ values for these nonHTC MOX experiments are shown along with those for the HTC experiments in Figure 6.5. While some non-HTC benchmarks with MOX fuel pin lattices had a $c_{k}$ value exceeding 0.80 , only one had a $c_{k}$ value that exceeded 0.9. The only sets of experiments shown by sensitivity/uncertainty analysis to be strongly applicable to the burnup credit cask model were the HTC experiments described in this report.

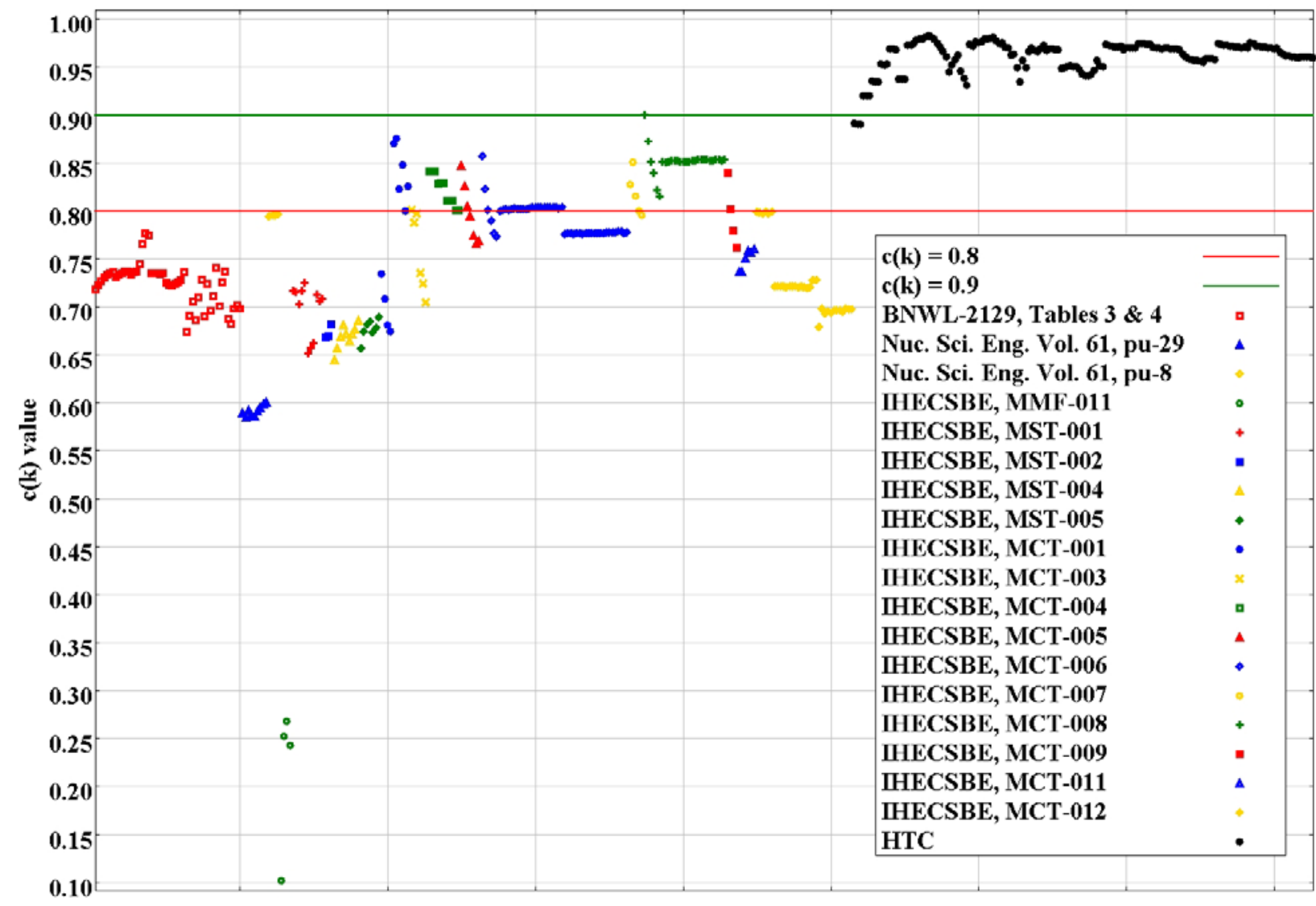

Figure 6.5 Comparison of non-HTC MOX and HTC experiments to the GBC-32 cask model with $40 \mathrm{GWd} / \mathrm{MTU}$ fuel

At the time the sensitivity and uncertainty analyses were performed for this report, ORNL staff had performed sensitivity analyses for 257 non-HTC MOX critical experiments. Of these, 78 critical experiments yielded $c_{k}$ values $\geq 0.8$ and an additional 46 IHECSBE and 7 non-IHECSBE cases yielded $c_{k}$ values between 0.75 and 0.8 . Some of these cases in the latter group may yield $c_{k}$ values of 0.8 or higher for different cask models or for casks loaded with fuel with a different burnup. There are additional MOX critical experiments documented in the IHECSBE that have not yet been analyzed by ORNL staff and which may also yield $c_{k}$ values $\geq 0.8$. The $c_{k}$ values calculated for the potentially useful MOX critical configurations described in the IHECSBE are provided in Table 6.1. 
Table 6.1 Calculated $c_{\mathrm{k}}$ values for non-HTC MOX experiments compared with GBC-32 model loaded with W $17 \times 17$ fuel burned to 40 GWd/MTU

\begin{tabular}{|c|c|c|c|c|c|c|c|}
\hline \multicolumn{8}{|c|}{ MOX critical experiments $-c_{k} \geq 0.8$} \\
\hline$\underline{\text { Expmt-Case* }}$ & $\underline{\mathrm{c}}_{\mathrm{k}}$ & Expmt-Case & $\underline{c_{\mathrm{k}}}$ & Expmt-Case & $\underline{c_{k}}$ & Expmt-Case & $\underline{\mathrm{c}_{\mathrm{k}}}$ \\
\hline МCT-002-01 & 0.8701 & МCT-005-03 & 0.8041 & MCT-006-24 & 0.8032 & МCT-008-12 & 0.8522 \\
\hline МCT-002-02 & 0.8755 & MCT-006-01 & 0.8570 & MCT-006-25 & 0.8031 & MCT-008-13 & 0.8517 \\
\hline MCT-002-03 & 0.8231 & МСТ-006-02 & 0.8229 & МCT-006-26 & 0.8031 & МCT-008-14 & 0.8516 \\
\hline МCT-002-04 & 0.8477 & MCT-006-03 & 0.8010 & MCT-006-27 & 0.8026 & MCT-008-15 & 0.8515 \\
\hline MCT-002-05 & 0.8002 & MCT-006-08 & 0.8005 & MCT-006-28 & 0.8031 & МCT-008-16 & 0.8518 \\
\hline МCT-002-06 & 0.8253 & MCT-006-09 & 0.8013 & MCT-007-01 & 0.8505 & MCT-008-17 & 0.8528 \\
\hline МCT-003-01 & 0.8004 & МСТ-006-10 & 0.8010 & МCТ-007-02 & 0.8276 & МСТ-008-18 & 0.8528 \\
\hline МCT-004-01 & 0.8410 & МCT-006-11 & 0.8020 & MCT-007-03 & 0.8158 & МCТ-008-19 & 0.8535 \\
\hline MCT-004-02 & 0.8416 & MCT-006-12 & 0.8023 & MCT-008-01 & 0.9002 & МCТ-008-20 & 0.8534 \\
\hline МСТ-004-03 & 0.8413 & МСТ-006-13 & 0.8017 & MCT-008-02 & 0.8726 & MCT-008-21 & 0.8532 \\
\hline МCT-004-04 & 0.8286 & МCT-006-14 & 0.8013 & MCT-008-03 & 0.8515 & МСТ-008-22 & 0.8533 \\
\hline МCT-004-05 & 0.8292 & MCT-006-15 & 0.8020 & MCT-008-04 & 0.8394 & MCT-008-23 & 0.8527 \\
\hline МCT-004-06 & 0.8291 & МСТ-006-16 & 0.8020 & MCT-008-05 & 0.8222 & MCT-008-24 & 0.8529 \\
\hline МCT-004-07 & 0.8107 & МCT-006-17 & 0.8028 & MCT-008-06 & 0.8156 & $\mathrm{MC}$ & 0.8531 \\
\hline МCТ-004-08 & 0.8113 & MCT-006-18 & 0.8035 & MCT-008-07 & 0.8515 & MCT-008-26 & 0.8530 \\
\hline МСТ-004-09 & 0.8111 & МСТ-006-19 & 0.8033 & MCT-008-08 & 0.8510 & МCT-008-27 & 0.8524 \\
\hline МCT-004-10 & 0.8007 & МСТ-006-20 & 0.8036 & МСТ-008-09 & 0.8516 & MCT-008-28 & 0.8532 \\
\hline МCT-004-11 & 0.8007 & MCT-006-21 & 0.8038 & MCT-008-10 & 0.8521 & МCТ-009-02 & 0.8392 \\
\hline MCT-005-01 & 0.8469 & MCT-006-22 & 0.8036 & MCT-008-11 & 0.8524 & MCT-009-03 & 0.8013 \\
\hline MCT-005-02 & 0.8259 & МCT-006-23 & 0.8037 & & & & \\
\hline \multicolumn{8}{|c|}{ MOX Critical Experiments $-0.8>c_{k} \geq 0.75$} \\
\hline Expmt-Case & $\underline{\mathrm{c}}_{\mathrm{k}}$ & Expmt-Case & $\underline{c_{\mathrm{k}}}$ & Expmt-Case & $\underline{c}_{\underline{k}}$ & Expmt-Case & $\underline{\mathrm{c}_{\mathrm{k}}}$ \\
\hline МCT-003-02 & 0.7880 & МCT-006-31 & 0.7764 & MCT-006-43 & 0.7779 & МCT-009-05 & 0.7616 \\
\hline МCT-003-03 & 0.7968 & МCT-006-32 & 0.7762 & MCT-006-44 & 0.7777 & MCT-011-03 & 0.7503 \\
\hline MCT-005-04 & 0.7940 & MCT-006-33 & 0.7769 & MCT-006-45 & 0.7774 & MCT-011-04 & 0.7586 \\
\hline MCT-005-05 & 0.7735 & MCT-006-34 & 0.7770 & MCT-006-46 & 0.7779 & MCT-011-05 & 0.7563 \\
\hline MCT-005-06 & 0.7655 & МСТ-006-35 & 0.7758 & МCT-006-47 & 0.7782 & МCT-011-06 & 0.7601 \\
\hline МCT-005-07 & 0.7680 & МCТ-006-36 & 0.7766 & MCТ-006-48 & 0.7782 & МCТ-012-01 & 0.7985 \\
\hline МСТ-006-04 & 0.7901 & МCТ-006-37 & 0.7771 & МCТ-006-49 & 0.7770 & МСТ-012-02 & 0.7979 \\
\hline МCТ-006-05 & 0.7764 & МCТ-006-38 & 0.7767 & MCT-006-50 & 0.7777 & MCT-012-03 & 0.7968 \\
\hline МСТ-006-06 & 0.7726 & МСТ-006-39 & 0.7767 & MCТ-007-04 & 0.7998 & МСТ-012-04 & 0.7986 \\
\hline МCТ-006-07 & 0.7997 & MCT-006-40 & 0.7771 & MCT-007-05 & 0.7948 & MCT-012-05 & 0.7975 \\
\hline МСТ-006-29 & 0.7754 & МCT-006-41 & 0.7766 & МCТ-009-04 & 0.7793 & МСТ-012-06 & 0.7993 \\
\hline MCT-006-30 & 0.7771 & MCT-006-42 & 0.7770 & & & & \\
\hline
\end{tabular}

* IHECSBE ${ }^{6}$ evaluation identifier and case number. 
One reason for the higher $c_{k}$ values generated by the HTC experiments is that the fuel used for the nonHTC MOX experiments contained a different isotopic mix of uranium and plutonium than is found in burned fuel. MOX critical experiments typically contain either depleted or natural uranium, along with plutonium that is mostly ${ }^{239} \mathrm{Pu}$. Uranium and plutonium composition information calculated for burned fuel is presented in Table 5.1. Burned fuel contains uranium that is still somewhat enriched in ${ }^{235} \mathrm{U}$ and also contains some ${ }^{236} \mathrm{U}$, along with ${ }^{237} \mathrm{~Np}$ and ${ }^{241} \mathrm{Am}$. The plutonium in burned fuel contains a significant portion of other isotopes, including ${ }^{240} \mathrm{Pu},{ }^{241} \mathrm{Pu}$, and ${ }^{242} \mathrm{Pu}$. While fission of ${ }^{241} \mathrm{Pu}$ is not a large contributor to the neutron population, its importance does increase with burnup, as shown in Figure 6.6.

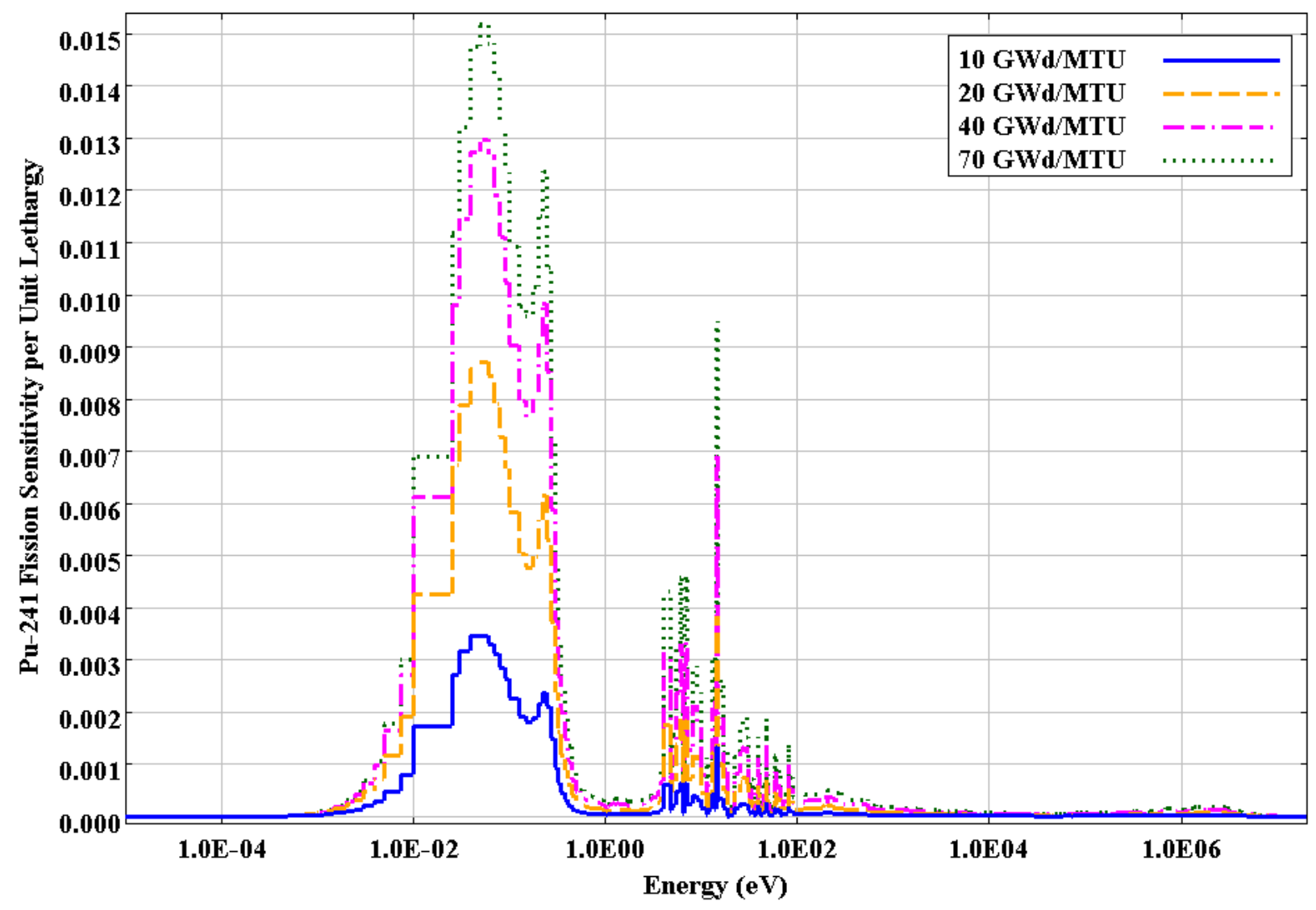

Figure 6.6 ${ }^{241} \mathrm{Pu}$ sensitivity as a function of burnup 
A comparison may be made between the HTC experiments and other MOX experiments by using an experiment evaluated in MIX-COMP-THERM-008 from Ref. 6 . These experiments were performed at the Pacific Northwest Laboratory in 1964. The fuel pins contained natural uranium oxide combined with $2.0 \mathrm{wt} \%$ plutonium oxide, over $70 \%$ of which was ${ }^{239} \mathrm{Pu}$. The remainder of the plutonium was approximately $23.5 \%{ }^{240} \mathrm{Pu}$ and $4 \%{ }^{241} \mathrm{Pu}$. This set of experiments is commonly used in validations for applications containing burned fuel. Experiment 1 in this evaluation (MCT-08-01) had a $\mathrm{c}_{\mathrm{k}}$ value of 0.906 when compared to the GBC-32 cask loaded with fuel burned to $40 \mathrm{GWd} / \mathrm{MTU}$. MCT-08-01 had the highest $c_{k}$ value of the non-HTC MOX critical experiments evaluated. This experiment may be compared to the HTC experiment, which had one of the highest $c_{k}$ values, $c_{k}=0.984$, when compared to the same GBC-32 cask model.

As discussed before, burned fuel in the GBC-32 model contains a higher fraction of ${ }^{235} \mathrm{U}$ than typical MOX experiment fuel. The HTC fuel contains uranium isotopes in a distribution that closely mimics burned fuel, while the MOX fuel in MCT-08-01 contains natural uranium. The impact of this on the sensitivity profiles for ${ }^{235} \mathrm{U}$ fission is shown in Figure 6.7. The sensitivity profiles for the GBC-32 cask model and for HTC Phase 2 Boron Case 7 (HTC2c7b) match fairly closely, while that for MCT08-01 is much smaller. Another important comparison involves ${ }^{238} \mathrm{U}$ capture in these three configurations. This comparison is shown in Figure 6.8. The profiles for the GBC-32 cask, HTC2c7b, and MCT-08-01 are very similar.

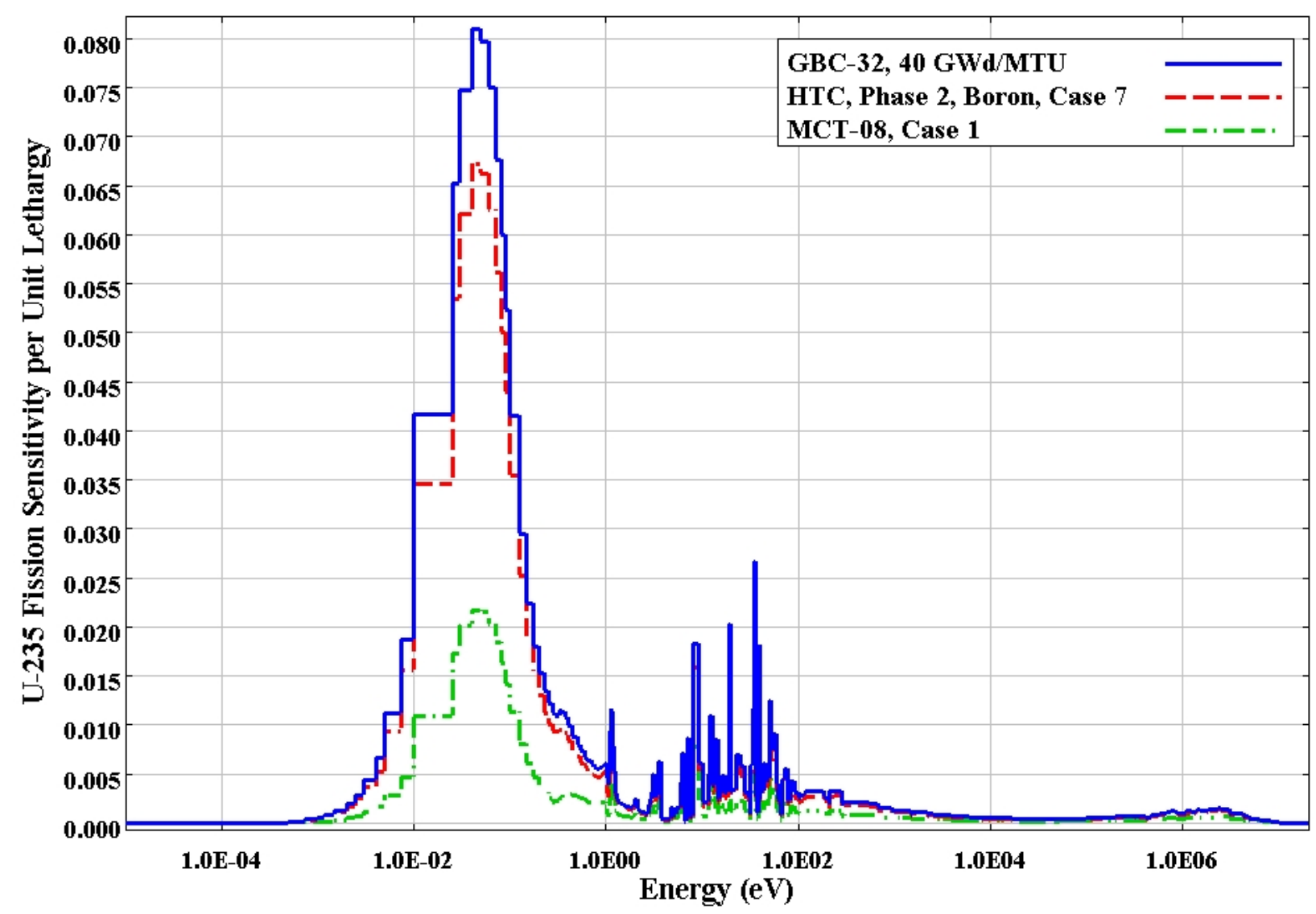

Figure 6.7 Comparison of sensitivity profiles for ${ }^{235} \mathrm{U}$ fission 


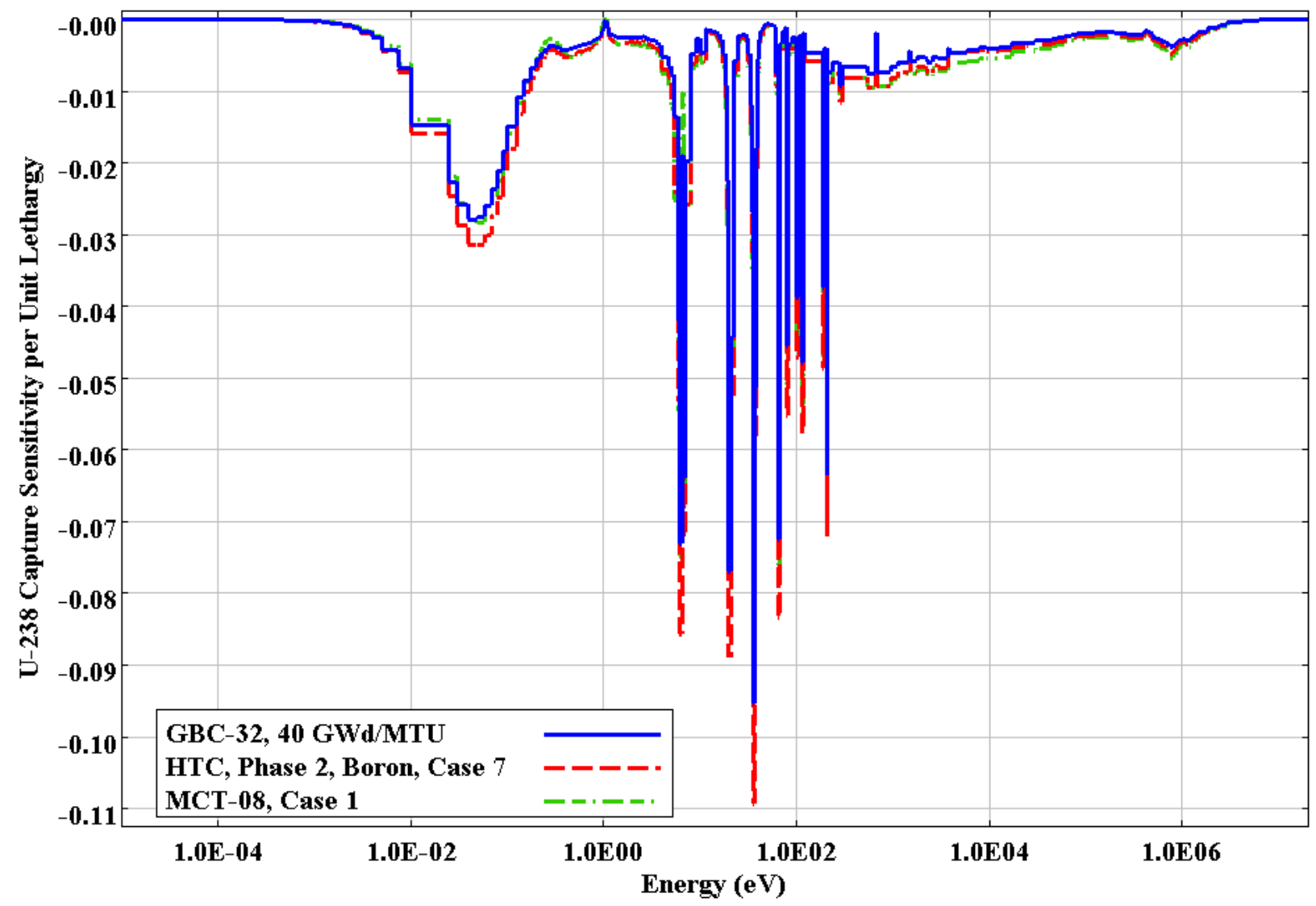

Figure 6.8 Comparison of sensitivity profiles for ${ }^{238} \mathrm{U}$ capture 
A comparison of sensitivity profiles for ${ }^{239} \mathrm{Pu}$ shows a different way in which experiments can be dissimilar. As shown in Figure 6.9, the sensitivity profile for ${ }^{239} \mathrm{Pu}$ fission in MCT-08-01 is much larger than for the GBC-32 cask or for HTC2c7b. While this may be used to show that MCT-08-01 provides validation for the plutonium in the GBC-32 fuel, the fact that the profile is quite different results in a lower value of $c_{k}$. If MCT-08-01 is used to calculate bias and bias uncertainty, the surplus ${ }^{239} \mathrm{Pu}$ fission sensitivity results in overemphasis of any bias that may result from the ${ }^{239} \mathrm{Pu}$ fission cross sections. The profiles for the HTC experiment and the GBC-32 cask are similar in size and shape, contributing to a higher value of $c_{k}$.

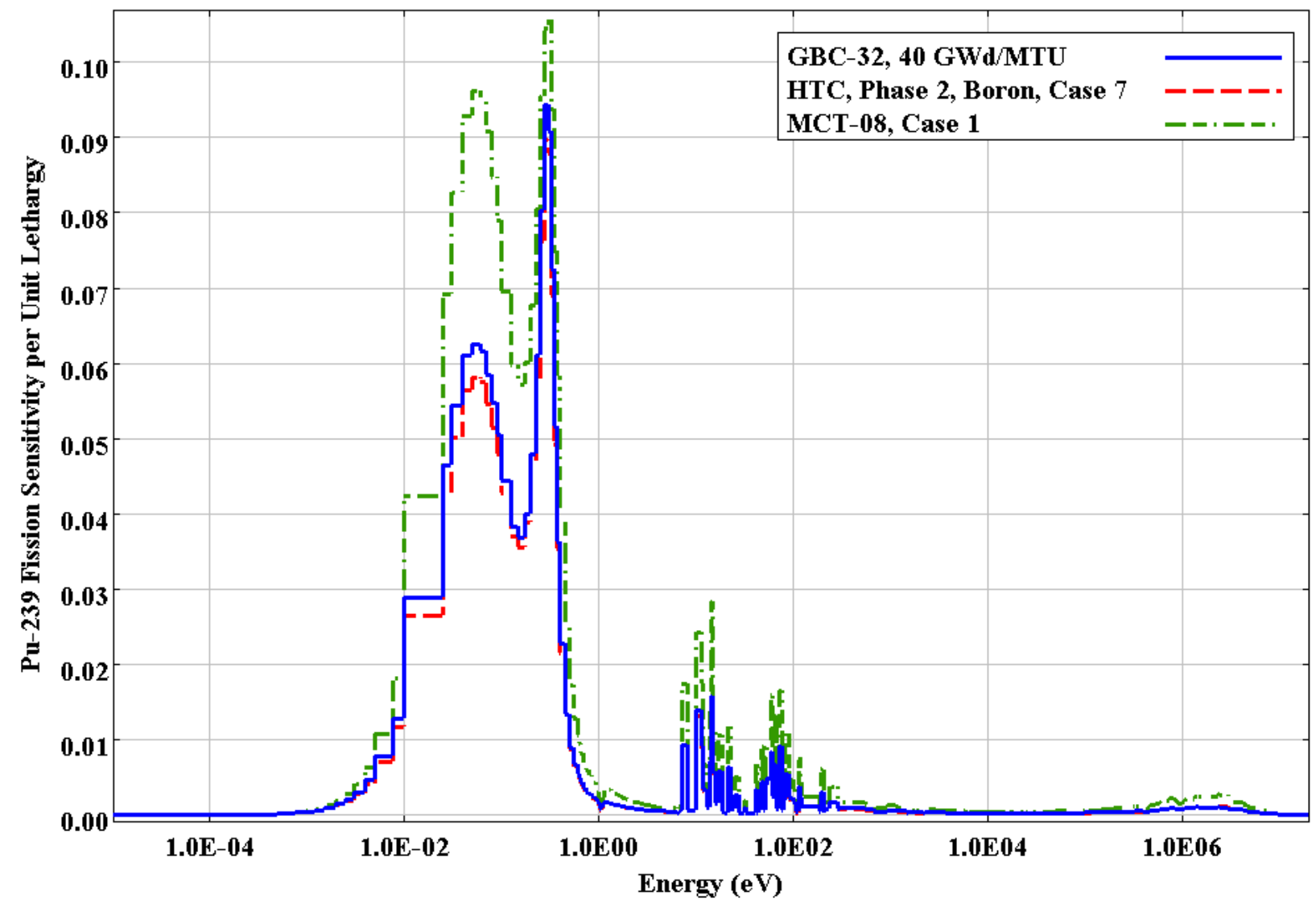

Figure 6.9 Comparison of sensitivity profiles for ${ }^{239} \mathrm{Pu}$ fission 
As discussed with Figure 6.6, ${ }^{241} \mathrm{Pu}$ fission plays a smaller but still significant role in the GBC-32 cask model. This role increases with increasing burnup. Figure 6.10 shows a comparison of the three sensitivity profiles for ${ }^{241} \mathrm{Pu}$ fission. While the overall magnitude of the sensitivity is not large, it is clear that the profile for the HTC2c7b experiment very closely matches that of the GBC-32 cask with 40-GWd/MTU burnup, while the sensitivity for MCT-08-01 is significantly lower than the other two. This also contributes to the higher value of $\mathrm{c}_{\mathrm{k}}$ for $\mathrm{HTC} 2 \mathrm{c} 7 \mathrm{~b}$.

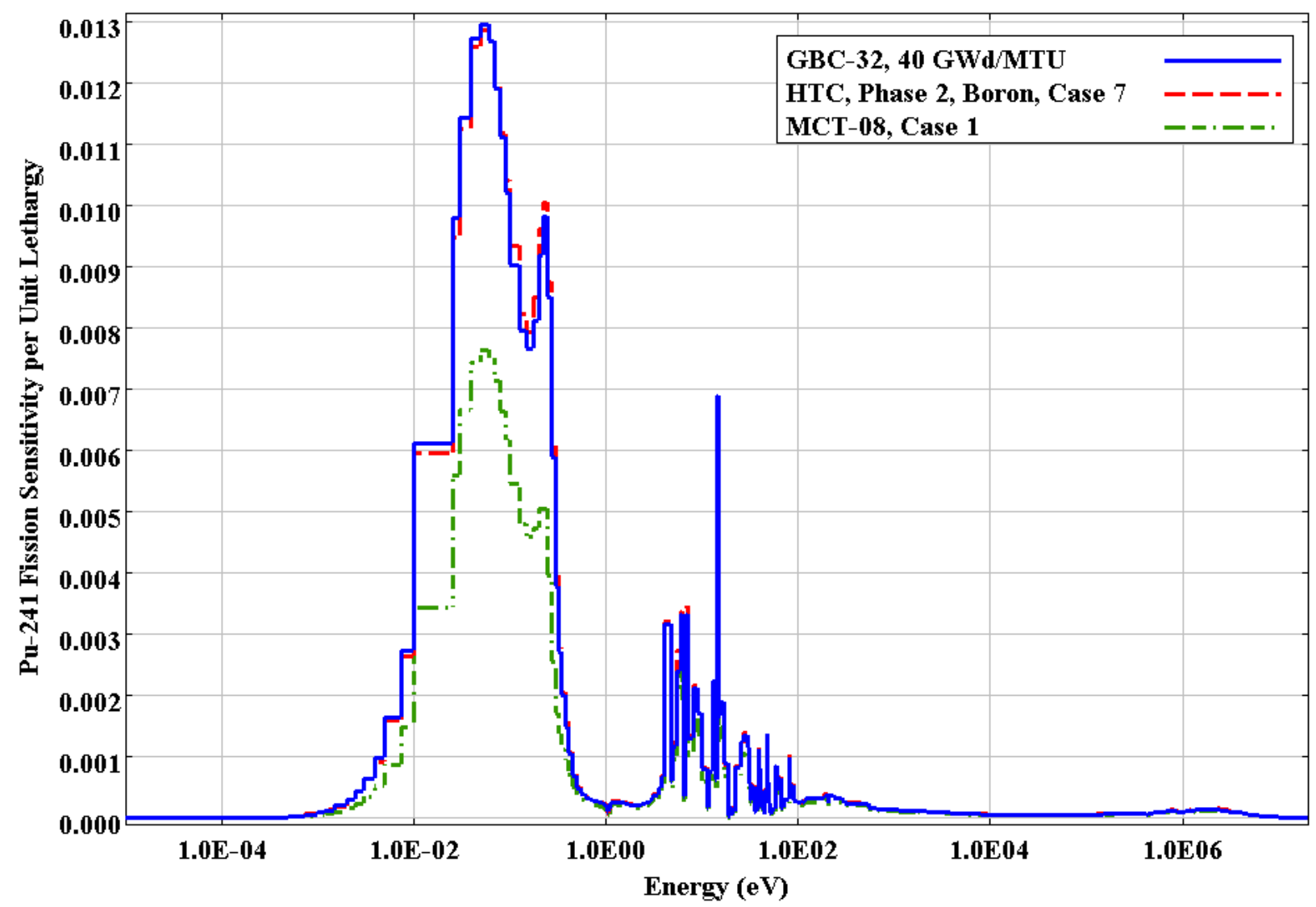

Figure 6.10 Comparison of sensitivity profiles for ${ }^{241} \mathrm{Pu}$ fission 
Due to decay of ${ }^{241} \mathrm{Pu}$ to ${ }^{241} \mathrm{Am}$ in the HTC experiment fuel rods, these experiments are also useful for validating the negative reactivity worth of ${ }^{241} \mathrm{Am}$ in burned fuel models. Figure 6.11 shows a comparison of the ${ }^{241} \mathrm{Am}$ total sensitivity profiles for the GBC-32 cask and for HTC Phase 2 boron case 7 . The profiles are very similar.

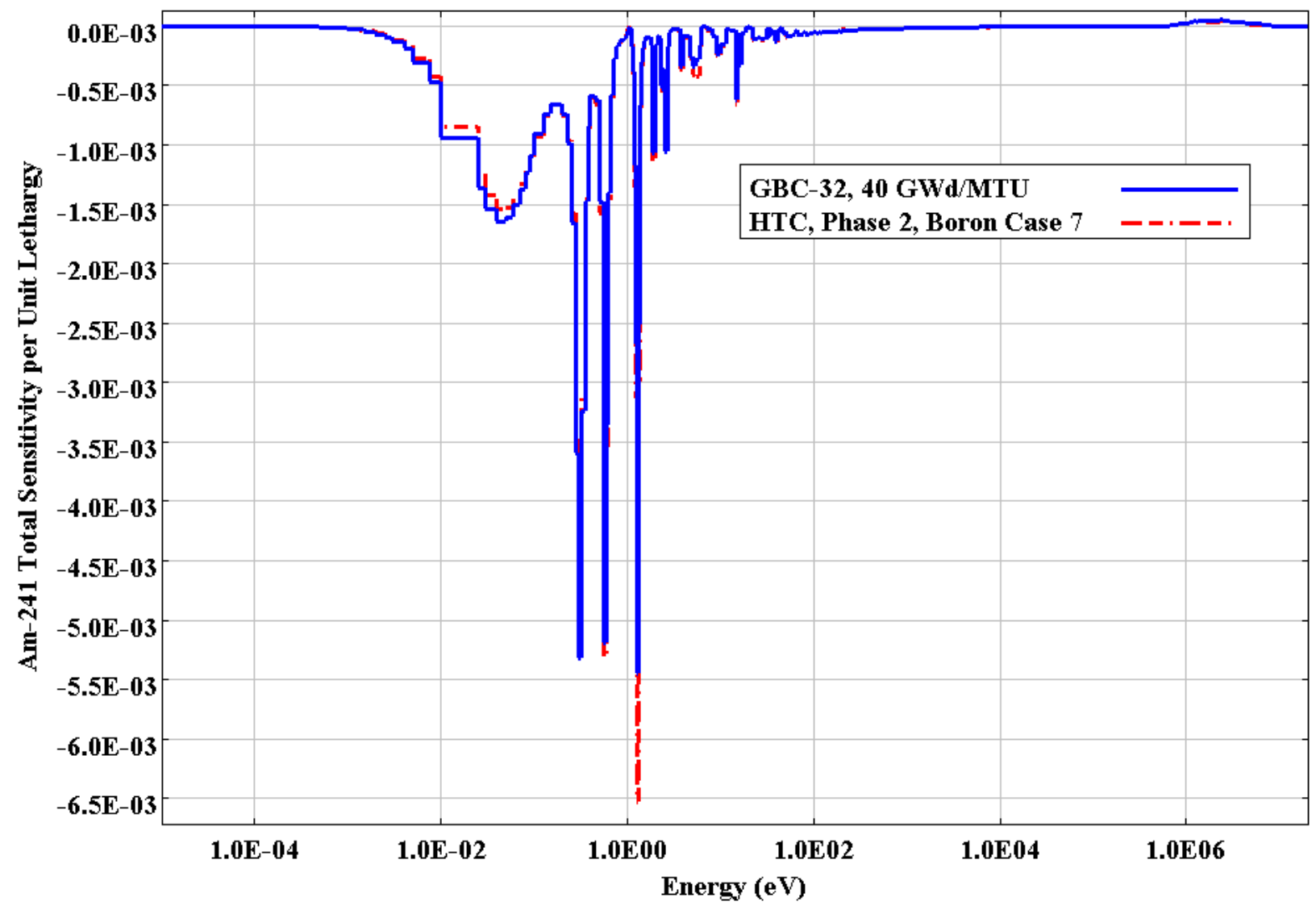

Figure 6.11 Comparison of total sensitivity profiles for ${ }^{241} \mathrm{Am}$ 
Another important reaction related to the $c_{k}$ value difference is hydrogen scattering in the water moderator around the fuel pins. This comparison is shown in Figure 6.12. The profiles for the IHECSBE MCT-008, case 1 and HTC Phase 2 boron case 7 experiments are more similar to the GBC-32 cask profile than is the HTC Phase 1, case 1 profile, which has the $2.3-\mathrm{cm}$ pin pitch.

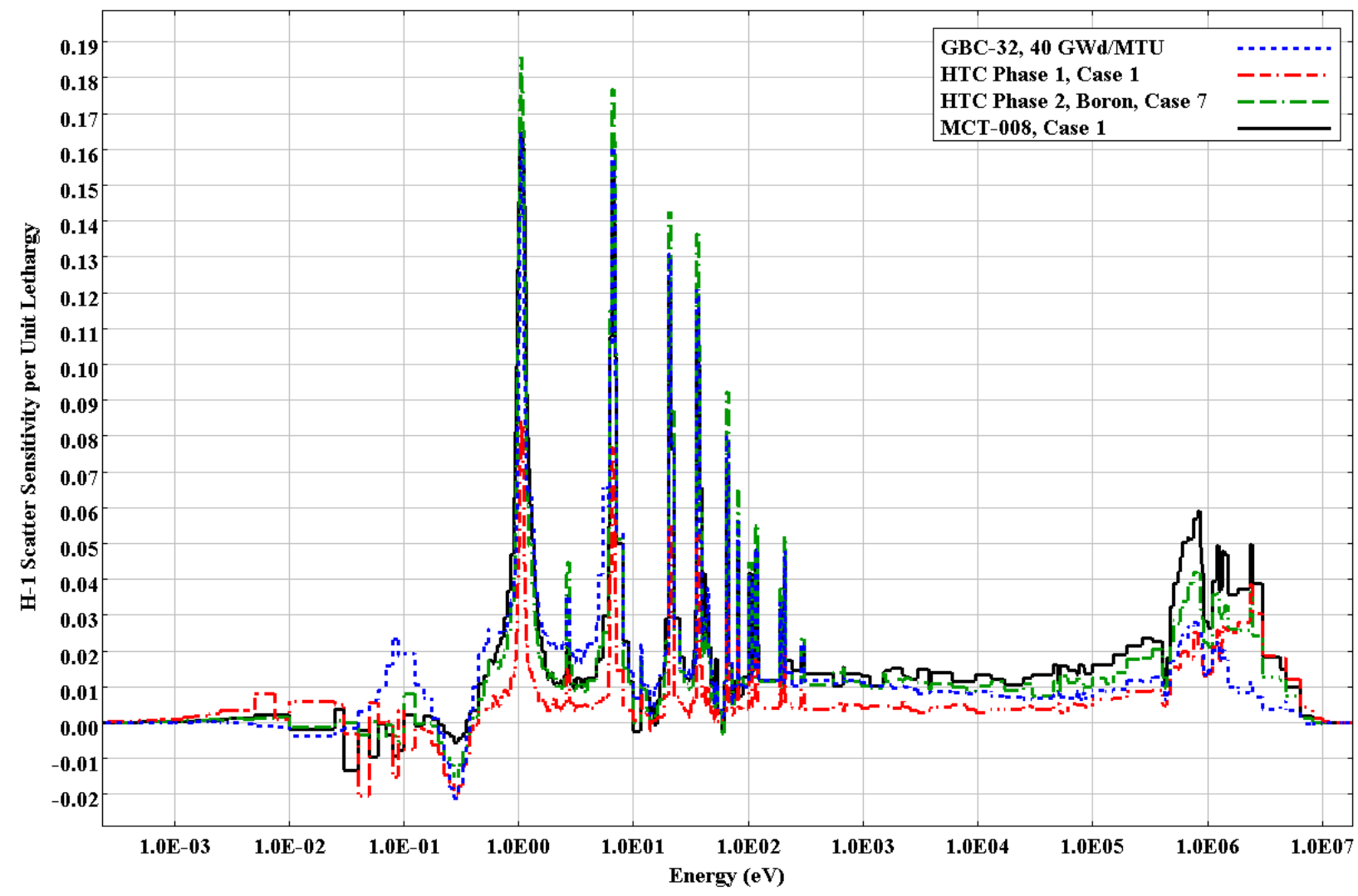

Figure 6.12 Comparison of sensitivity profiles for ${ }^{1} \mathrm{H}$ scatter

A question one might ask is why the HTC experiments, which have no fission products, appear to be so similar (i.e., have high $c_{\mathrm{k}}$ values) to burned fuel models that do include fission products. The standard TSUNAMI-IP output includes a $c_{k}$ calculation for the application, in this case the GBC-32, compared to itself. By definition, this comparison yields a $c_{k}$ value of 1 . When requested using the $c_{-}$long TSUNAMI-IP input parameter, the individual contributions from each nuclide/reaction pair toward the overall $c_{k}$ value are provided in the output. For the GBC-32 loaded with fuel burned to $40 \mathrm{GWd} / \mathrm{MTU}$, the total contribution of the top six fission products is 0.00470 . Consequently, not having them in an experiment reduces the experiment $\mathrm{c}_{\mathrm{k}}$ value by about 0.005 . The $\mathrm{c}_{\mathrm{k}}$ contribution is the nuclear data uncertainty converted to $k_{\text {eff }}$ uncertainty using the appropriate energy-dependent sensitivity profile. The fission product $\mathrm{c}_{\mathrm{k}}$ contribution is small because (1) the model is not nearly as sensitive to the fission product nuclear data as it is to the primary fissionable nuclides, moderators and absorbers, and (2) the fission product thermal capture cross sections are relatively simple and do not have large associated uncertainties. Given the significantly lower sensitivity of the calculated $k_{\text {eff }}$ value to the fission products compositions, relative to the actinide compositions, and the available fission product cross-section uncertainty data, the contribution of the fission products to the overall calculational bias should be relatively small. This does not mean that the bias due to the fission product compositions should be neglected, but rather that it is expected to be relatively small as compared to the bias due to the actinide 
compositions. Unfortunately, there are no publicly available laboratory critical experiments (LCEs) with uranium, plutonium, and fission products in compositions similar to burned fuel. The estimation of fission product biases or development of a conservative bounding value for fission product biases is being pursued at ORNL. 


\section{USL DETERMINATION}

The primary purpose of validation is to determine an appropriate upper subcritical limit (USL). For demonstration purposes, USLs were calculated using the HTC experiment data and data from some additional MOX experiments. USL determination must be performed using the applicant's specific cask and fuel assembly designs, and computational method. The analysis presented in this section is provided purely for illustrative purposes.

Version 1.4.4 of the USLSTATS program, which was distributed with SCALE 5.1, was used to calculate the USLs presented in this section. The USLSTATS program was derived from the V_STATS program. ${ }^{14}$ The input for USLSTATS is described in Appendix C of Ref. 15. The USLSTATS was modified by the SCALE development staff for use with TSUNAMI to support calculation of USLs based on extrapolation of sensitivity coefficients, such as $c_{k}$, to a value of 1.0, where the compared systems are considered to be identical for bias determination purposes.

The TSUNAMI-IP program was used to compare the sensitivity data for the 156 HTC experiment configurations and for an additional 257 MOX experiments, most of which are described in Ref. 6, with the GBC-32 cask model. The results presented in Figure 6.5 show that the HTC experiments are significantly more similar to the GBC-32 cask model than are the non-HTC MOX experiments and are therefore better for use in validation studies.

USLSTATS was used to calculate USLs as a function of trends in the energy of average lethargy of neutrons causing fission (EALF) and as a function of $c_{k}$ values. Use of other trending parameters may also be useful and valid. The GBC-32 loaded with fuel burned to $40 \mathrm{GWd} / \mathrm{MTU}$ and flooded with water had an EALF of $0.2859 \mathrm{eV}$. The following USLSTATS input parameters were used for the USL calculations described in this section:

$\mathrm{P}=$ proportion of population falling above lower tolerance level, 0.999

$1-\gamma=$ confidence on fit, 0.95

$\alpha=$ confidence on proportion $\mathrm{P}, 0.999$

$\mathrm{x}_{\min }=$ minimum value of parameter $\mathrm{X}$ for which USL correlations are computed, 0.0

$\mathrm{x}_{\max }=$ maximum value of parameter $\mathrm{X}$ for which USL correlations are computed, 1.0

$\sigma_{\text {sample }}=$ estimate in average standard deviation of all input values of $k_{\text {eff, }}-1$ indicating that uncertainties are provided for each experiment

$\Delta \mathrm{k}_{\mathrm{m}} \quad=$ administrative margin used to ensure subcriticality, 0.050

USLs were calculated for the following eight cases:

Case 1 non-HTC MOX experiments with EALF $<1.0$

USL based on EALF trend interpolated at $0.2859 \mathrm{eV}$

Case 2 non-HTC MOX experiments with EALF $<1.0$

USL based on $c_{k}$ trend extrapolated to 1.0

Case 3 non-HTC MOX experiments with EALF $<1.0$ and $c_{k}>0.8$ USL based on EALF trend interpolated at $0.2859 \mathrm{eV}$

Case 4 non-HTC MOX experiments with EALF $<1.0$ and $c_{k}>0.8$ USL based on $\mathrm{c}_{\mathrm{k}}$ trend extrapolated to 1.0 
Case 5 HTC and non-HTC MOX experiments with EALF $<1.0$ and $c_{k}>0.8$ USL based on EALF trend interpolated at $0.2859 \mathrm{eV}$

Case 6 HTC and non-HTC MOX experiments with EALF $<1.0$ and $c_{k}>0.8$ USL based on $\mathrm{c}_{\mathrm{k}}$ trend extrapolated to 1.0

Case 7 HTC Experiments with EALF $<1.0$ and $c_{k}>0.8$

USL based on EALF trend interpolated at $0.2859 \mathrm{eV}$.

Case $8 \quad$ HTC Experiments with EALF $<1.0$ and $\mathrm{c}_{\mathrm{k}}>0.8$

USL based on $c_{k}$ trend extrapolated to 1.0

The results for the USL calculations are presented in Table 7.1, and USLSTATS trending plots are provided as Figures 7.1-7.8. In the following table and figures, USL-1 is the USLSTATS method 1, confidence band with administrative margin, and USL-2 is the USLSTATS method 2, single-sided uniform width closed interval approach. Comparison of the USL-1 values for cases 1 through 4 shows that using TSUNAMI to identify critical experiments that are similar to the GBC-32 yields higher, lesslimiting USLs. Addition of the HTC experiments in cases 5 and 6 produces even higher USLs.

Comparison of Figures 7.4 and 7.6 shows how the addition of the HTC experiments improves the distribution of critical experiments presented as a function of similarity, $\mathrm{c}_{\mathrm{k}}$. Cases 7 and 8 show the USLs resulting when only the HTC experiments are used.

Table 7.1 Results from USL calculations

\begin{tabular}{ccccl}
\hline $\begin{array}{c}\text { USL } \\
\text { case }\end{array}$ & $\begin{array}{c}\text { Number of } \\
\text { experiments }\end{array}$ & $\begin{array}{c}\text { Normality } \\
\text { test }\end{array}$ & USL-1 & \multicolumn{1}{c}{ Description } \\
\hline 1 & 225 & Failed & 0.9287 & $\begin{array}{l}\text { MOX Experiments, } \\
\text { EALF }<1.0 \mathrm{eV}, \text { EALF trend }\end{array}$ \\
\hline 2 & 225 & Failed & 0.9144 & $\begin{array}{l}\text { MOX Experiments, } \\
\text { EALF }<1.0 \mathrm{eV}, \mathrm{c}_{\mathrm{k}} \text { trend }\end{array}$ \\
\hline 3 & 78 & Passed & 0.9366 & $\begin{array}{l}\text { MOX Experiments, } \\
\text { EALF }<1.0 \mathrm{eV}, \mathrm{c}_{\mathrm{k}}>0.8, \text { EALF trend }\end{array}$ \\
\hline 5 & 78 & Passed & 0.9392 & $\begin{array}{l}\text { MOX Experiments, } \\
\text { EALF }<1.0 \mathrm{eV}, \mathrm{c}_{\mathrm{k}}>0.8, \mathrm{c}_{\mathrm{k}} \text { trend }\end{array}$ \\
\hline 6 & 234 & Passed & 0.9398 & $\begin{array}{l}\text { HTC and MOX Experiments, } \\
\text { EALF }<1.0 \mathrm{eV}, \mathrm{c}_{\mathrm{k}}>0.8, \text { EALF trend }\end{array}$ \\
\hline 7 & 156 & Passed & 0.9428 & $\begin{array}{l}\mathrm{HTC} \text { and MOX Experiments, } \\
\text { EALF }<1.0 \mathrm{eV}, \mathrm{c}_{\mathrm{k}}>0.8, \mathrm{c}_{\mathrm{k}} \text { trend }\end{array}$ \\
\hline 8 & 156 & Failed & 0.9417 & $\begin{array}{l}\text { HTC Experiments, } \\
\text { EALF }<1.0 \mathrm{eV}, \mathrm{c}_{\mathrm{k}}>0.8, \text { EALF trend }\end{array}$ \\
\hline
\end{tabular}

The trends in the results for each trending parameter, cases 1, 3, 5, and 7 for EALF and cases 2, 4, 6, and 8 for $\mathrm{c}_{\mathrm{k}}$, may be understood by examination of the intermediate results provided by USLSTATS. Case 3 uses a subset of the critical configurations from case 1, retaining only those critical configurations that, when compared with the GBC-32 model, have $c_{\mathrm{k}}$ values greater than 0.8 . For case 1 , the $225 k_{\text {eff }}$ values range from 0.9762 to 1.04598 . While the $78 k_{\text {eff }}$ values range from 0.9893 to 1.0065 for case 3 . While the average $k_{\text {eff }}$ value for case 1 is higher than for case 3, the USL reported for case 1 is lower than the USL for case 3 because the uncertainty associated with the range of $k_{\text {eff }}$ values is much lower for case 3 
than for case 1. Case 5 includes the 78 case 3 critical configurations and the 156 HTC configurations. The $156 \mathrm{HTC} k_{\text {eff }}$ values range from 0.9924 to 1.0030 . Including the HTC configurations adds 156 data points that are all within the $k_{\text {eff }}$ value range for the case $3 \mathrm{MOX}$ configurations. The additional data points reduce the uncertainty associated with the spread of the data, resulting in a slightly higher USL for case 5. Case 7 is the same as case 5 with the 78 non-HTC MOX configurations removed. In this case, the fitted $k_{\text {eff }}$ value at $0.2859 \mathrm{eV}$ is slightly lower than the value for case 5, but the HTC $k_{\text {eff }}$ values are within a smaller range, producing a smaller uncertainty that more than offsets the loss of the 78 non-HTC MOX data points. Thus, the USL for case 7 is a little higher than the USL for case 5.

The EALF trending cases were used to calculate a USL at an EALF of $0.2859 \mathrm{eV}$. For the $c_{k}$ value trending cases, the USL is calculated by extrapolating to a $c_{k}$ value of 1.0. Case 4 uses a subset of the configurations used in case 2 . The USL produced for case 4 is higher than that produced for case 2 because the linearly extrapolated $k_{\text {eff }}$ value for case 4 is significantly higher than that extrapolated for case 2. Additionally, the reduced spread of the $k_{\text {eff }}$ values yields a lower uncertainty for the case 4 USL. Cases 4 and 6 yield nearly the same extrapolated $k_{\text {eff }}$ values, but the addition of the HTC data reduces the distance of extrapolation, thus reducing the uncertainty associated with extrapolation. This results in a higher USL for case 6 . Case 8 is similar to case 6 except the non-HTC MOX cases have been removed. The extrapolated $k_{\text {eff }}$ value is lower for case 8 than it is for case 6 . This together with an increased uncertainty due to the loss of the 78 non-HTC MOX data points results in a slightly lower USL for case 8 . 


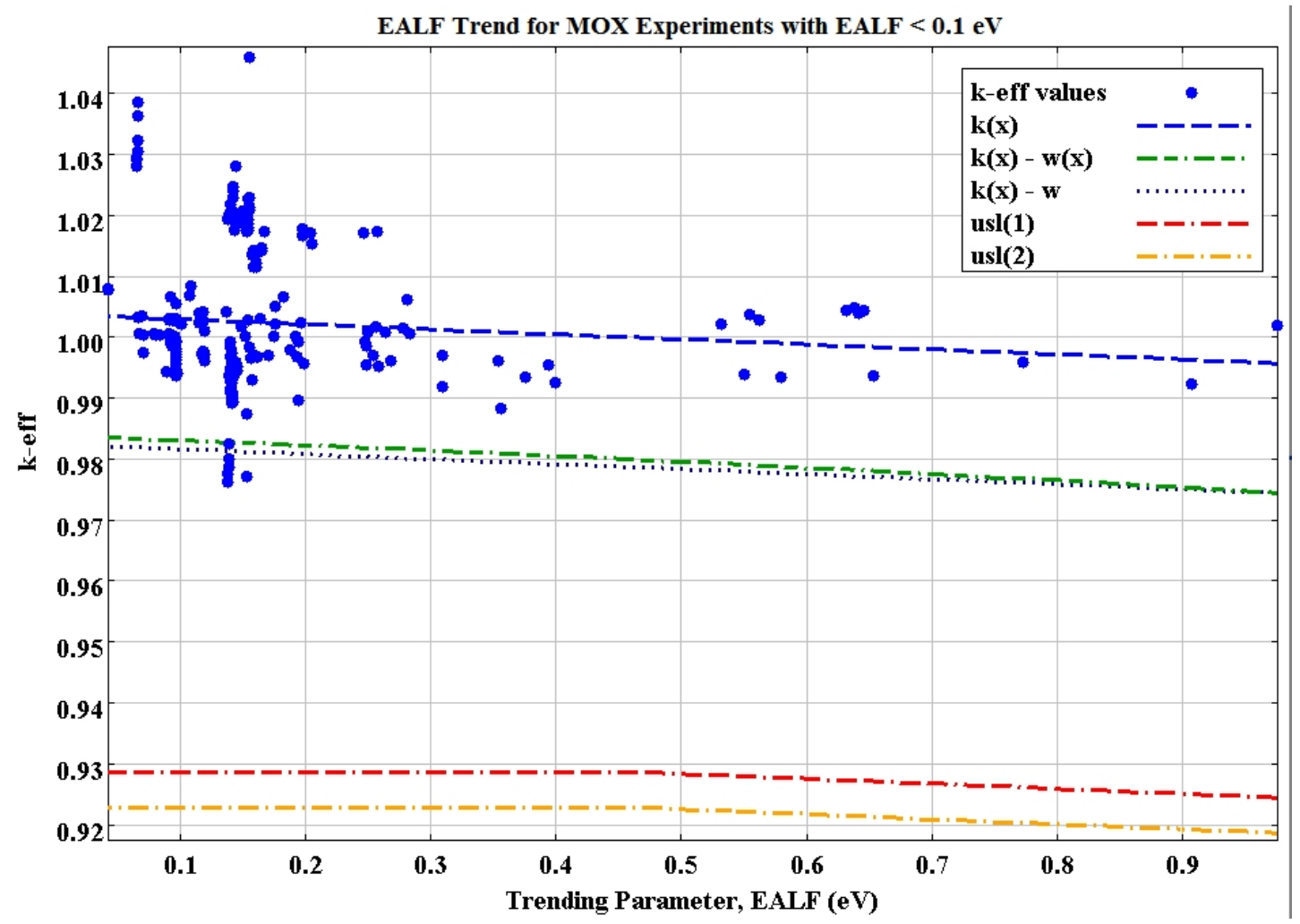

Figure 7.1 USLSTATS trending figure for Case 1

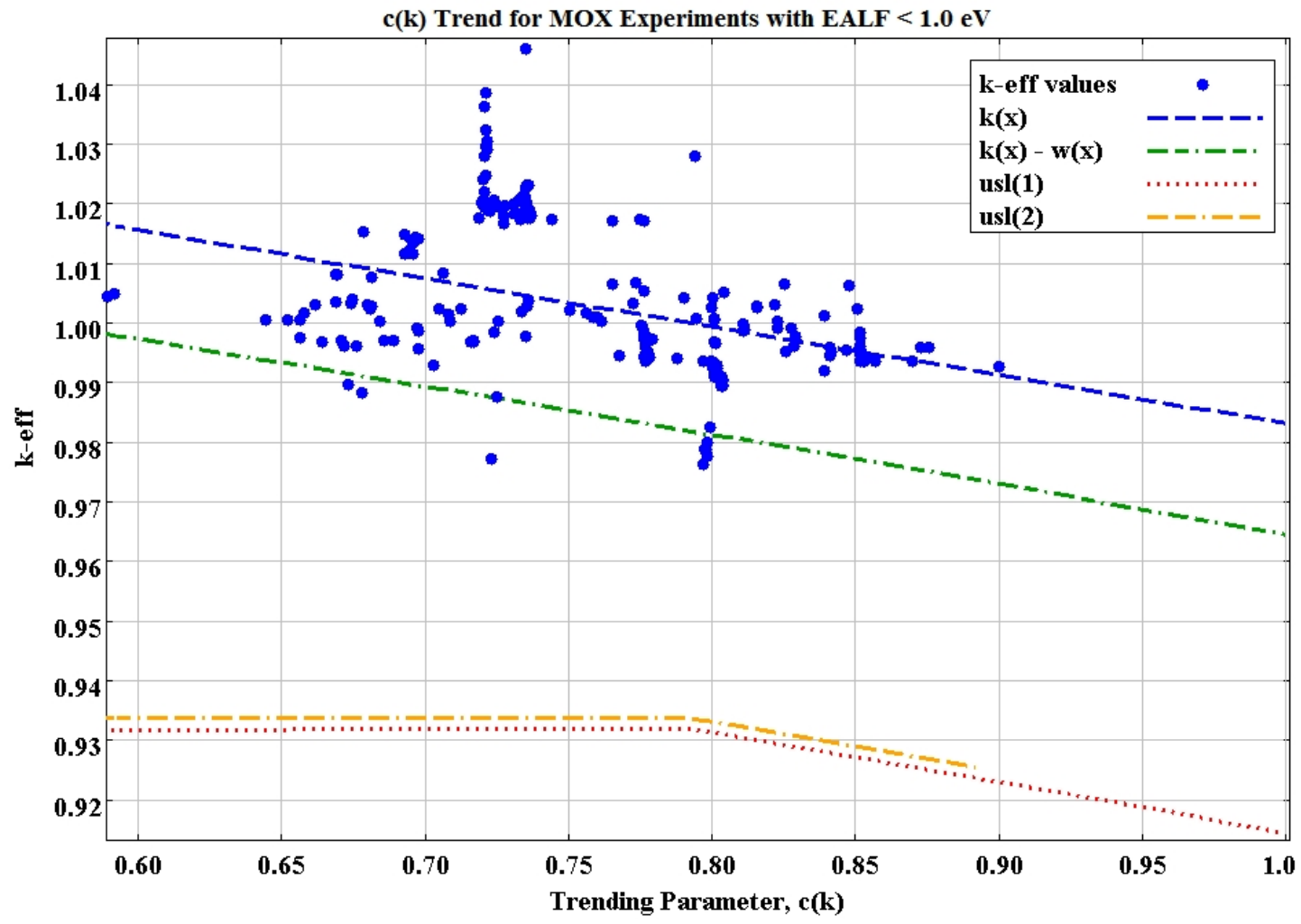

Figure 7.2 USLSTATS trending figure for Case 2 


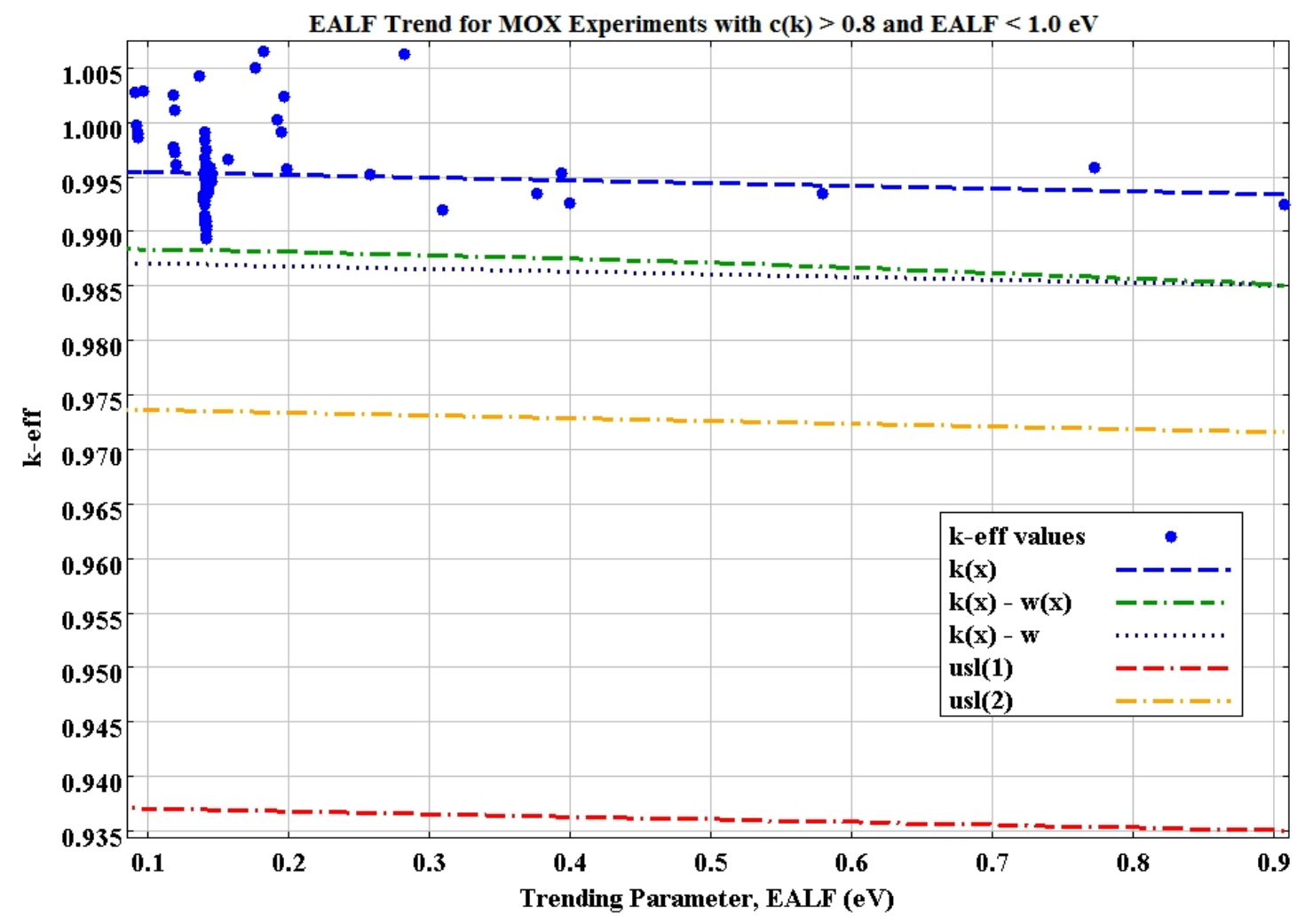

Figure 7.3 USLSTATS trending figure for Case 3

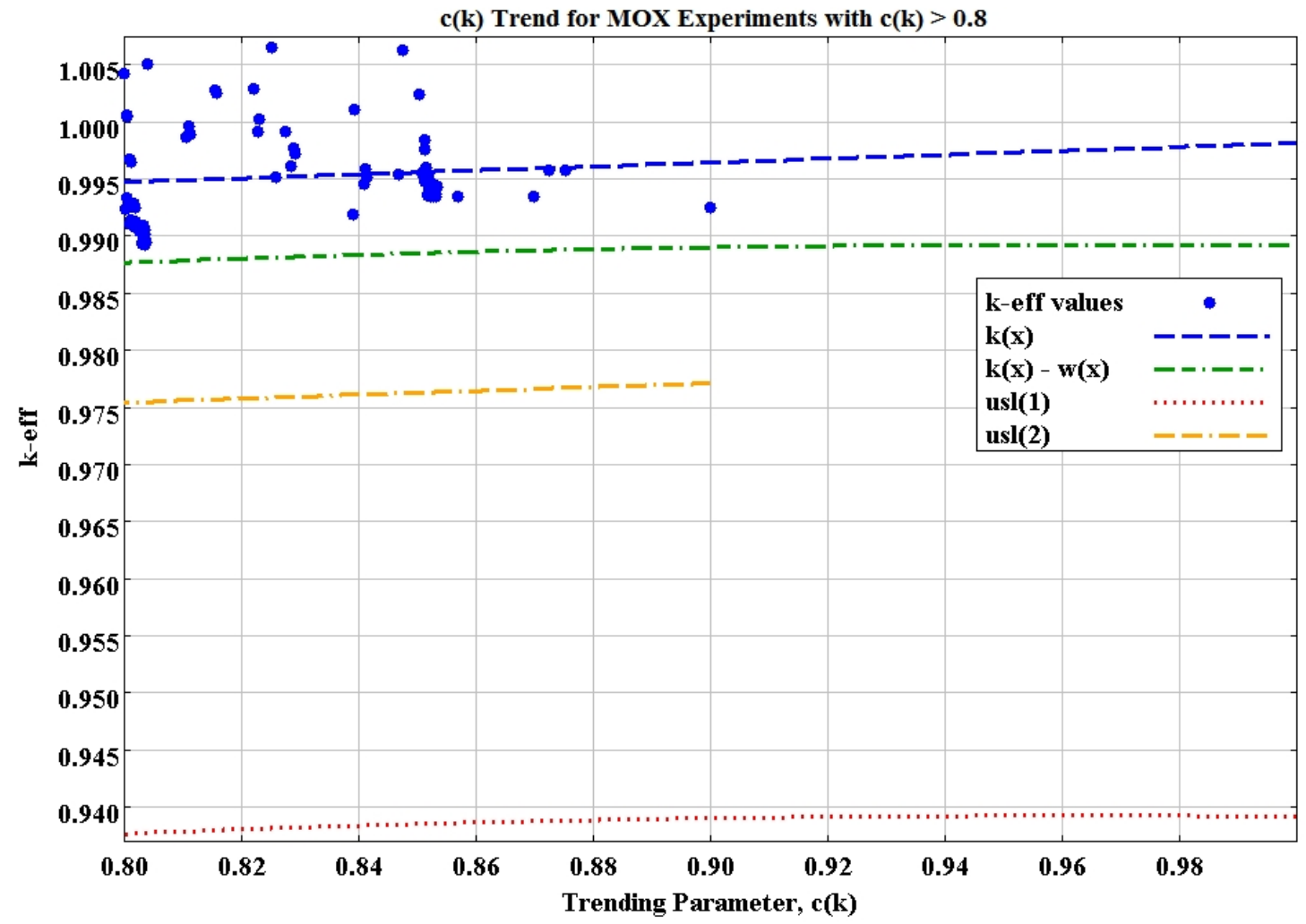

Figure 7.4 USLSTATS trending figure for Case 4 
EALF Trend for HTC and MOX Experiments with $\mathrm{c}(\mathrm{k})>0.8$

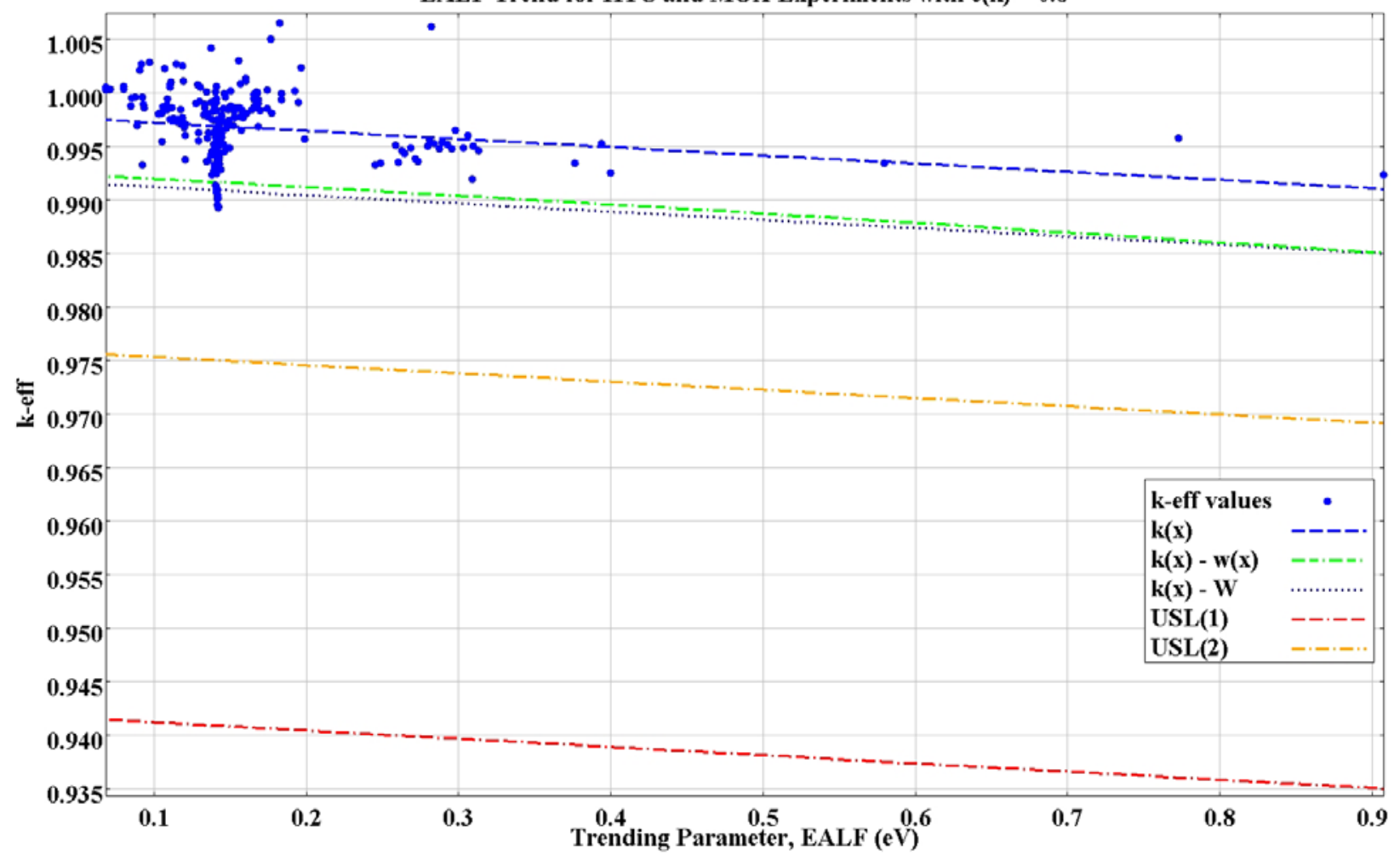

Figure 7.5 USLSTATS trending figure for Case 5

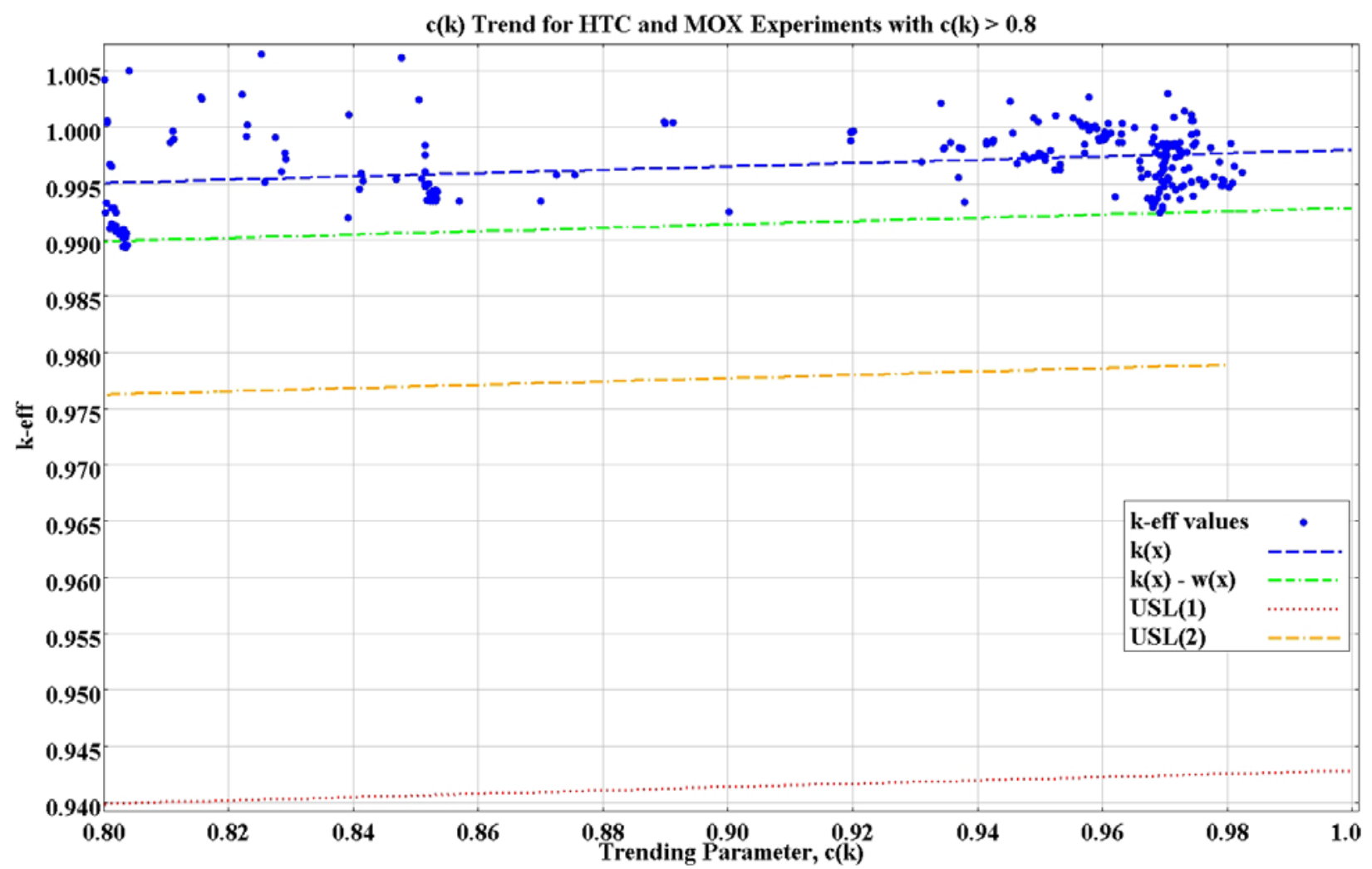

Figure 7.6 USLSTATS trending figure for Case 6 


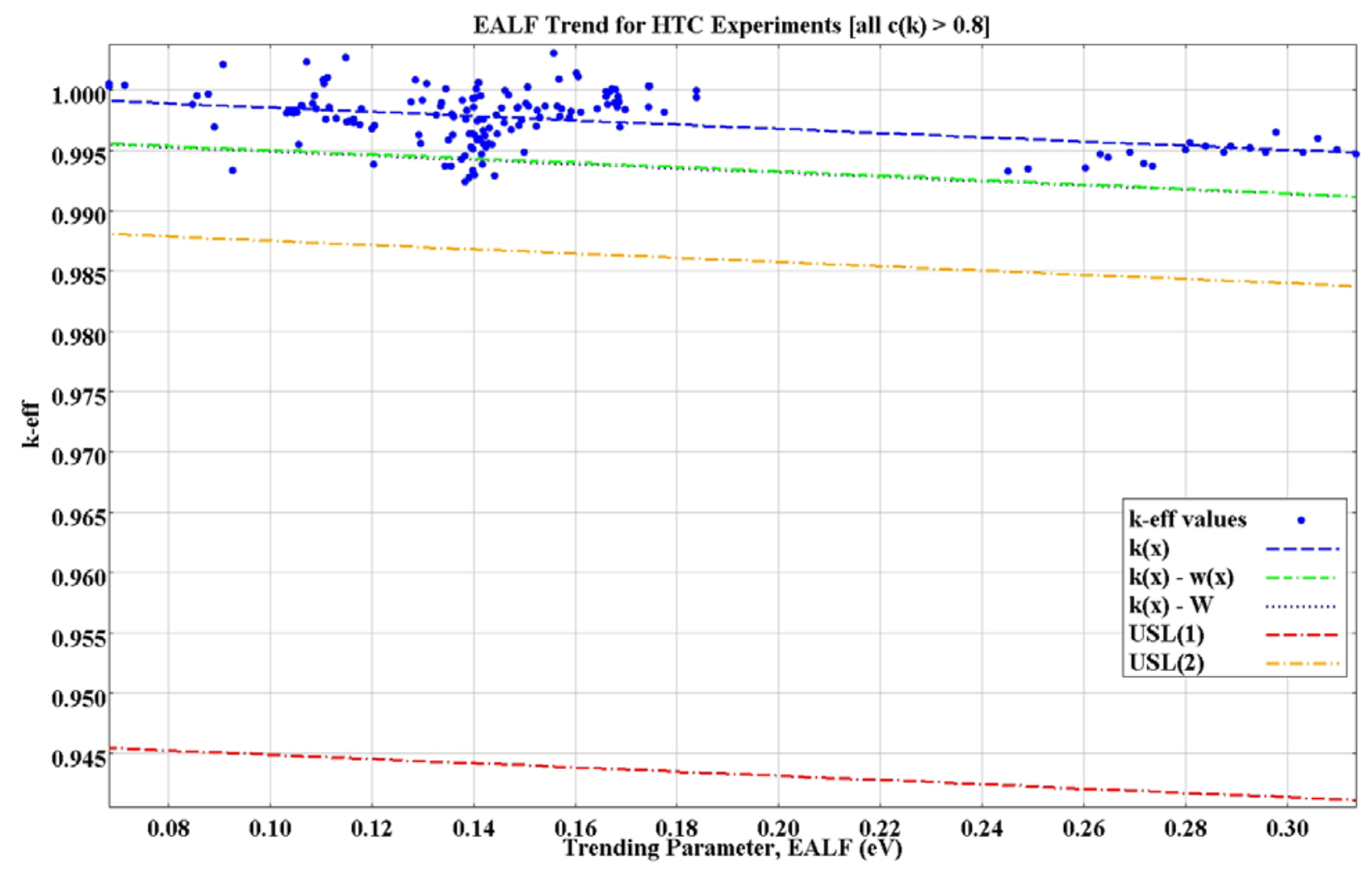

Figure 7.7 USLSTATS trending figure for Case 7

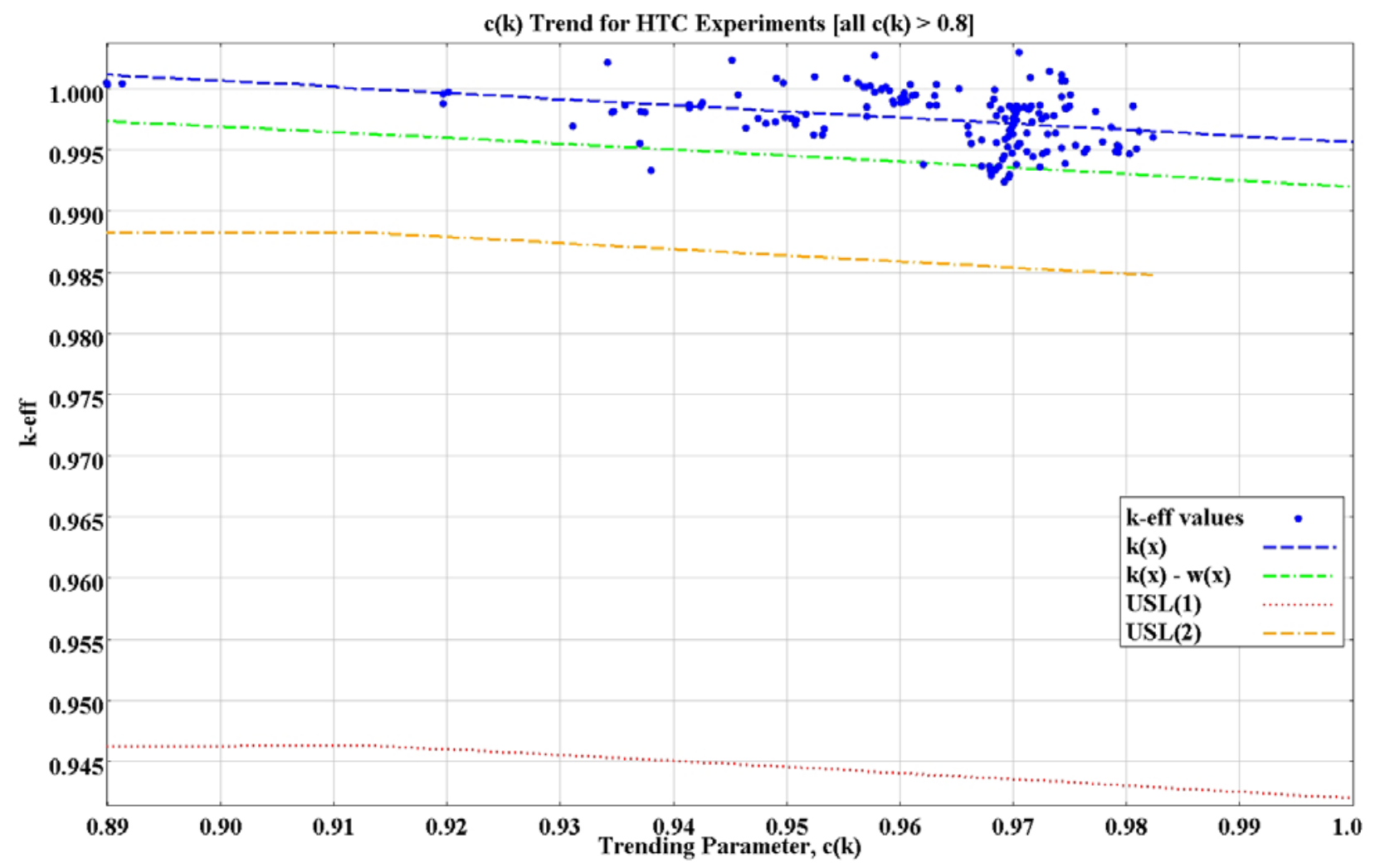

Figure 7.8 USLSTATS trending figure for Case 8 



\section{CONCLUSIONS}

The HTC experiments have many characteristics that make them very valuable for the validation of actinide-only burnup credit applications. The uranium and plutonium composition in the HTC experiment rods is significantly more similar to burned fuel than the fuel composition in other MOX benchmark critical experiments. This similarity has been assessed qualitatively by comparison of sensitivity profiles and quantitatively by using sensitivity/uncertainty analysis, confirming that the HTC experiments are significantly more applicable to the validation of burnup credit calculations than other generally available MOX experiments. When compared to the high-capacity generic burnup credit cask model loaded with fuel with assembly average burnup varying from 10 to $70 \mathrm{GWd} / \mathrm{MTU}$, the HTC experiments were found to be applicable for use in validation of these models for fuel burnups ranging from 20 to $70 \mathrm{GWd} / \mathrm{MTU}$ and marginally applicable for fuel with a $10 \mathrm{GWd} / \mathrm{MTU}$ burnup. The HTC experiments were designed and executed with a high level of rigor, resulting in experimental uncertainties that are lower than many of the earlier MOX experiments. References 1-4, together with information provided in Appendix A of this report, provide sufficient data to allow for development of either detailed or simplified computational models of the critical configurations. The HTC experiments substantially improve the technical basis for validation by adding a significant number of experiments that are significantly more similar to burnup credit safety analysis models than are the other generally available and somewhat applicable MOX critical experiments. 



\section{REFERENCES}

1. F. Fernex, "Programme HTC - Phase 1 : Réseaux de crayons dans l'eau pure (Water-moderated and reflected simple arrays) Réévaluation des expériences,” DSU/SEC/T/2005-33/D.R., Institut de Radioprotection et de Sûreté Nucléaire, 2008.

2. F. Fernex, "Programme HTC - Phase 2 : Réseaux simples en eau empoisonnée (bore et gadolinium) (Reflected simple arrays moderated by poisoned water with gadolinium or boron) Réévaluation des expériences,” DSU/SEC/T/2005-38/D.R., Institut de Radioprotection et de Sûreté Nucléaire, 2008.

3. F. Fernex, "Programme HTC - Phase 3 : Configurations "stockage en piscine" (Pool storage)

Réévaluation des expériences,” DSU/SEC/T/2005-37/D.R., Institut de Radioprotection et de Sûreté Nucléaire, 2008.

4. F. Fernex, "Programme HTC - Phase 4 : Configurations "châteaux de transport" (Shipping cask) Réévaluation des expériences,” DSU/SEC/T/2005-36/D.R., Institut de Radioprotection et de Sûreté Nucléaire, 2008.

5. D. E. Mueller and J. C. Wagner, "Application of Sensitivity/Uncertainty Methods to Burnup Credit Validation,” presented at the International Atomic Energy Agency (IAEA) Technical Committee Meeting on Advances in Applications of Burnup Credit to Enhance Spent Fuel Transportation, Storage, Reprocessing and Disposition, August 29-September 2, 2005, London.

6. International Handbook of Evaluated Criticality Safety Benchmark Experiments, NEA/NSC/DOC(95)03, NEA Nuclear Science Committee, September 2006.

7. Personal communication between D. E. Mueller (ORNL) and E. Letang (IRSN).

8. SCALE: A Modular Code System for Performing Standardized Computer Analyses for Licensing Evaluation, ORNL/TM-2005/39, Version 5.1, Vols. I-III (November 2006). Available from Radiation Safety Information Computational Center at Oak Ridge National Laboratory as CCC-732.

9. J. C. Wagner, Computational Benchmark for Estimation of Reactivity Margin from Fission Products and Minor Actinides in PWR Burnup Credit, NUREG/CR-6747 (ORNL/TM-2000/306), prepared for the U.S. Nuclear Regulatory Commission by Oak Ridge National Laboratory, Oak Ridge, Tenn., October 2001.

10. "STARBUCS: A SCALE Control Module for Automated Criticality Safety Analyses Using Burnup Credit," in SCALE: A Modular Code System for Performing Standardized Computer Analyses for Licensing Evaluation, ORNL/TM-2005/39, Version 5.1, Vols. I-III (November 2006). Available from Radiation Safety Information Computational Center at Oak Ridge National Laboratory as CCC-732.

11. I. C. Gauld, Strategies for Application of Isotopic Uncertainties in Burnup Credit, NUREG/CR6811 (ORNL/TM-2001/257, prepared for the U.S. Nuclear Regulatory Commission by Oak Ridge National Laboratory, Oak Ridge, Tenn., June 2003. (Table A.1, data point No. 42)

12. F. Fernex, E. Girault, and J. F. Thro, “'HTC Ageing' Experimental Programme Concerning the Qualification of the Decrease from ${ }^{241} \mathrm{Pu}$ to ${ }^{241} \mathrm{Am}$,” Proceedings of ICNC 2007, St. Petersburg, Russia, May 28-June 1, 2007.

13. B. L. Broadhead, B. T. Rearden, C. M. Hopper, J. J. Wagschal, and C. V. Parks, "Sensitivity- and Uncertainty-Based Criticality Safety Validation Techniques,” Nucl. Sci. Eng. 146, 340-366 (2004).

14. V. R. Cain, A Computer Code to Perform Analyses of Criticality Validation Results, Y/DD-574, Martin Marietta Energy Systems, Inc., Oak Ridge Y-12 Plant, September 1995.

15. J. J. Lichtenwalter, S. M. Bowman, M. D. DeHart, and C. M. Hopper, Criticality Benchmark Guide for Light-Water-Reactor Fuel in Transportation and Storage Packages, NUREG/CR-6361 (ORNL/TM-13211), prepared for the U.S. Nuclear Regulatory Commission by Oak Ridge National Laboratory, Oak Ridge, Tenn., March 1997. 


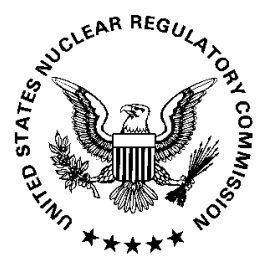

NUREG/CR-6979

ORNL/TM-2007/083 